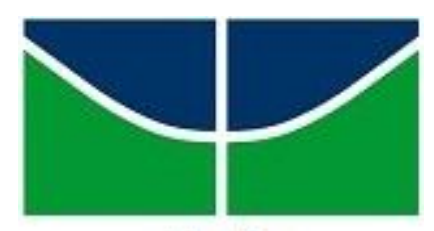

UnB

Centro de Estudos Avançados Multidisciplinares

Programa de Pós-Graduação em Desenvolvimento, Sociedade e Cooperação Internacional

HELAYNE RODRIGUES DA SILVA

\title{
AVALIAÇÃO DE POLÍTICAS PÚBLICAS: UM ESTUDO SOBRE AUDITORIA DE DESEMPENHO NO TRIBUNAL DE CONTAS DA UNIÃO BRASILEIRO
}

BRASÍLIA, DF 
UNIVERSIDADE DE BRASÍLIA

Centro de Estudos Avançados Multidisciplinares

Programa de Pós-Graduação em Desenvolvimento, Sociedade e Cooperação Internacional

\section{AVALIAÇÃO DE POLÍTICAS PÚBLICAS: UM ESTUDO SOBRE AUDITORIA DE DESEMPENHO NO TRIBUNAL DE CONTAS DA UNIÃO BRASILEIRO}

HELAYNE RODRIGUES DA SILVA

ORIENTADORA: Dsc. ANA MARIA NOGALES VASCONCELOS

DISSERTAÇÃO DE MESTRADO

BRASÍLIA, DF

ABRIL/2015 
UNIVERSIDADE DE BRASÍLIA

Centro de Estudos Avançados Multidisciplinares

Programa de Pós-Graduação em Desenvolvimento, Sociedade e Cooperação Internacional

HELAYNE RODRIGUES DA SILVA

\section{AVALIAÇÃO DE POLÍTICAS PÚBLICAS: UM ESTUDO SOBRE AUDITORIA DE DESEMPENHO NO TRIBUNAL DE CONTAS DA UNIÃO BRASILEIRO}

DISSERTAÇÃO APRESENTADA AO PROGRAMA DE PÓS-GRADUAÇÃO EM DESENVOLVIMENTO, SOCIEDADE E COOPERAÇÃO INTERNACIONAL DA UNIVERSIDADE DE BRASÍLIA, COMO REQUISITO PARCIAL PARA OBTENÇÃO DO TÍTULO DE MESTRE EM DESENVOLVIMENTO, SOCIEDADE E COOPERAÇÃO INTERNACIONAL. ÁREA DE CONCENTRAÇÃO: DESENVOLVIMENTO E POLITICAS PÚBLICAS.

Prof. ${ }^{a}$ Ana Maria Nogales Vasconcelos (PPGDSCI-UnB) (Orientadora)

Prof. Paulo de Martino Jannuzzi (IBGE/MDS)

(Examinador Externo)

Prof. Joaquim José Soares Neto (PPGDSCI-UnB)

(Examinador Interno)

Prof. ${ }^{\text {a }}$ Doriana Daroit (ADM-UnB)

(Suplente)

BRASÍLIA, DF

30 DE ABRIL DE 2015 


\section{FICHA CATALOGRÁFICA}

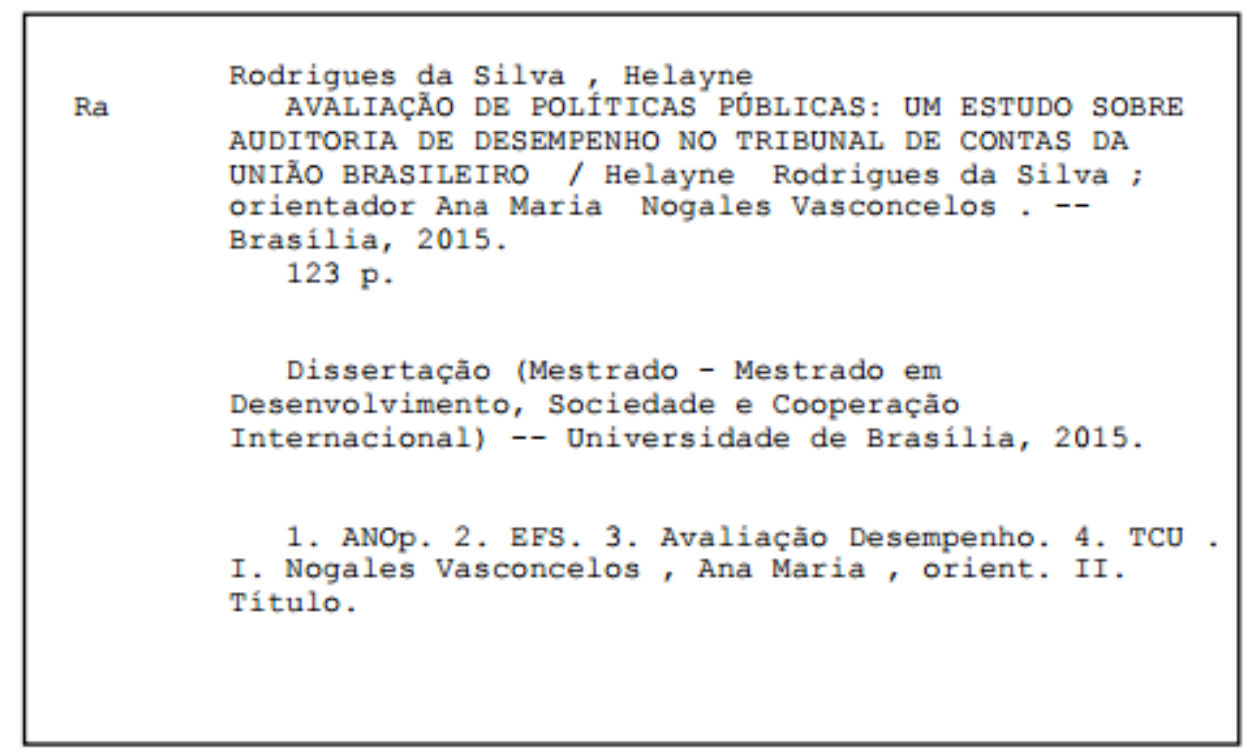




\section{REFERÊNCIA BIBLIOGRÁFICA}

SILVA, H. R. (2015). AVALIAÇÃO DE POLÍTICAS PÚBLICAS: UM ESTUDO SOBRE AUDITORIA DE DESEMPENHO NO TRIBUNAL DE CONTAS DA UNIÃO BRASILEIRO Dissertação de Mestrado em Desenvolvimento, Sociedade e Cooperação Internacional, Publicação E.DM-A19/15, Pós-Graduação em Desenvolvimento, Sociedade e Cooperação Internacional, Universidade de Brasília, Brasília, DF, 127p.

\section{CESSÃO DE DIREITOS}

AUTORA: Helayne Rodrigues da Silva

TÍTULO: AVALIAÇÃO DE POLÍTICAS PÚBLICAS: UM ESTUDO SOBRE AUDITORIA DE DESEMPENHO NO TRIBUNAL DE CONTAS DA UNIÃO BRASILEIRO

GRAU: Mestre ANO: 2015

É concedida à Universidade de Brasília permissão para reproduzir cópias desta dissertação de mestrado e para emprestar ou vender tais cópias somente para propósitos acadêmicos e científicos. A autora reserva outros direitos de publicação e nenhuma parte dessa dissertação de mestrado pode ser reproduzida sem autorização por escrito da autora.

Helayne Rodrigues da Silva

ENDEREÇO: QRSW 7 BLOCO B5 APT 201

CEP: 71.675-725. Brasília/DF, Brasil.

Email: helayners@hotmail.com 


\section{AGRADECIMENTOS}

Dedico especial agradecimento a querida professora Ana Maria Nogales, orientadora dedicada que com sabedoria soube dirigir-me os passos e os pensamentos para o alcance de meus objetivos.

Aos Professores Paulo Jannuzzi e Joaquim Neto, membros da Banca Examinadora, por terem atendido ao convite para desempenhar este papel, dispondo de seu tempo e conhecimento para analisar este trabalho. 


\section{RESUMO}

O paradigma da Nova Gestão Pública proporciona reflexões quanto a eficiência do Estado subordinado ao critério da efetividade. O conceito de "boas práticas", atualmente, transcende a verificação da correta aplicação de recursos e se estende a verificação e mensuração dos seus efeitos. O Brasil vem avançando em iniciativas institucionais de criação e adequação de métodos que auxiliem o processo do Planejamento Federal por meio da incorporação e criação de técnicas de avaliação e monitoramento de programas e políticas. Esta pesquisa aborda o processo de institucionalização da Auditoria Operacional- ANOp no Tribunal de Contas da União - TCU. Verifica-se como esse processo contribuiu para a construção e consolidação da função de avaliador de políticas públicas do TCU, por intermédio da problematização e da sistematização de reflexões sobre: sua motivação, mudanças ocorridas e a levantamento dos resultados.

Palavras-chaves: ANOp, EFS, Avaliação Desempenho, TCU 


\begin{abstract}
The paradigm of New Public Management provides reflections as the state's efficiency under the criterion of effectiveness. The concept of "best practices" currently transcends the verification of the correct application of resources and extends the verification and measurement of its effects. Brazil has been advancing in institutional initiatives to create and adequacy of methods that help the process of Federal Planning through the incorporation and establishment of valuation techniques and monitoring programs and policies. This exploratory and multidisciplinary research addresses the process of institutionalization of Audit operationally ANOP in the Court of the Union - TCU through the Neo-institutionalism theory. Checking how this process contributed to the construction and consolidation of public policies evaluator function of TCU, through questioning and systematization of reflections on: motivation, changes occurred and the survey results.
\end{abstract}

Keywords: ANOP, SAI, Performance evaluation, TCU 


\section{LISTA DE QUADROS}

Quadro 1. Histórico do Planejamento e Gestão Publica no Brasil. .........................................24

Quadro 2. Principais tipos de auditoria de desempenho por país ..........................................29

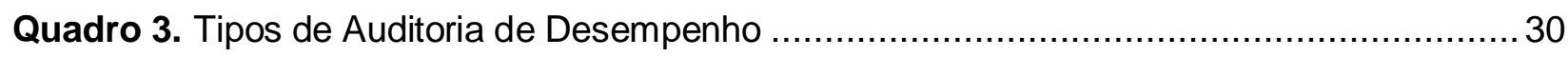

Quadro 4. Informações investigadas na análise preliminar ................................................53

Quadro 5 Técnicas mais utilizadas na etapa de planejamento............................................54

Quadro 6. Exemplo de formulação de questões e subquestões ............................................64

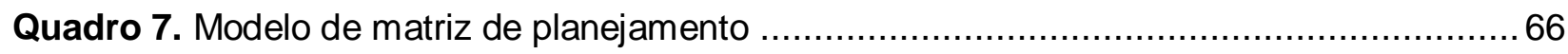

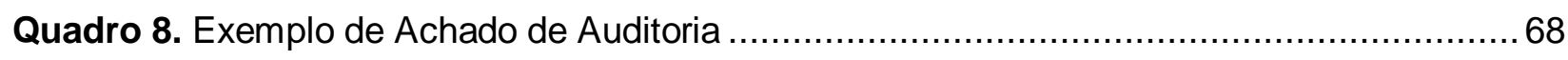

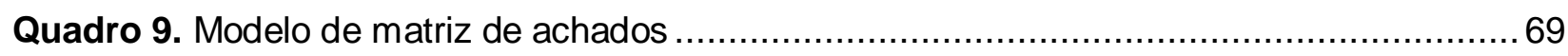

Quadro 10. Classificação do estágio de implementação das deliberações .............................. 73

Quadro 11. Operacionalização do constructo institucionalização ........................................79

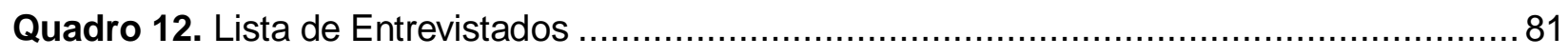

Quadro 13. Roteiro de Entrevista - Lista de Perguntas ....................................................... 82

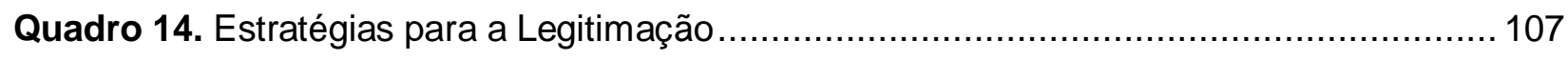

Quadro 15. Quadro de Auditorias Operacionais e seus resultados. ....................................110 


\section{LISTA DE FIGURAS}

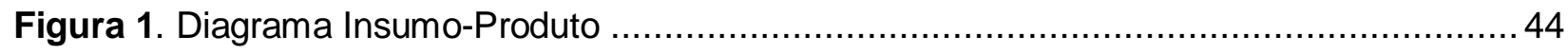

Figura 2: Ciclo de Auditoria Operacional. .......................................................... 47

Figura 3: Fluxograma das atividades do planejamento ......................................... 52

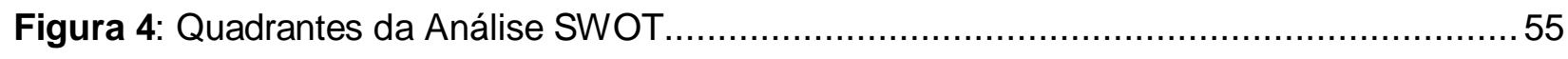

Figura 5: Matriz para avaliação do ambiente interno e externo ..................................... 55

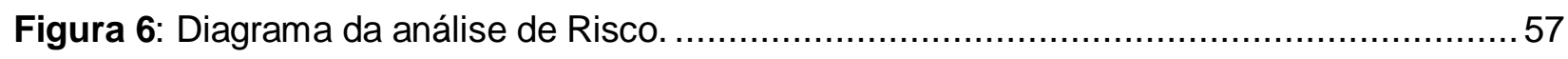

Figura 7: Exemplo: Mapa de produtos - Comunicação via memorando...............................60

Figura 8: Notações utilizadas em mapas de processo............................................. 62 


\section{LISTA DE TABELAS}

Tabela 1. Quantidade de avaliações por Ministérios entre 2005 e 2009................................90

Tabela 2. Tabela com o quantitativo de Auditorias por ano no TCU. .....................................94 


\section{LISTA DE SIGLAS}

TCU

EFS

ANOp

NBC

CFC

CEPAL

INTOSAI

GAO

SAUDI

CGU

SIGPLAN

PPA

ECA

NHS

SEAUDI

MPOG

SEPROG

SEMEC

SMA
Tribunal de Contas da União

Entidades de Fiscalização Superior

Auditoria Operacional

Norma Brasileira de Contabilidade

Conselho de Contabilidade Federal

Comissão Econômica para a América Latina e o Caribe

Organização Internacional de Entidades Fiscalizadores Superiores

Escritório de Contabilidade do Governo EUA

Secretaria de Auditoria

Controladoria Geral da União

Sistema que auxilia a elaboração e acompanhamento do plano plurianual

Plano Plurianual

Tribunal de Contas Europeu

Serviço Nacional de Saúde

Secretaria de Métodos Aplicados e Suporte à Auditoria

Ministério do Planejamento, Orçamento e Gestão

Secretaria de Fiscalização e Avaliação de Programas de Governo

Secretaria de Métodos

Sistema de monitoramento e avaliação 


\section{SUMÁRIO}

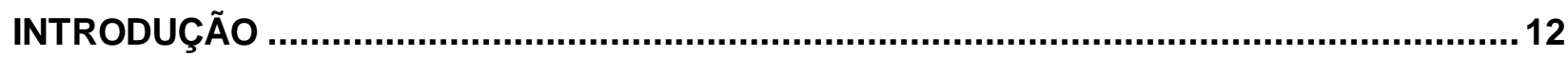

CAPÍTULO I - AVALIAÇÃO E AUDITORIA: AFASTAMENTOS E APROXIMAÇÕES..............15

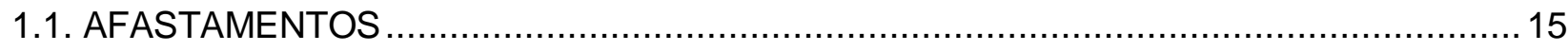

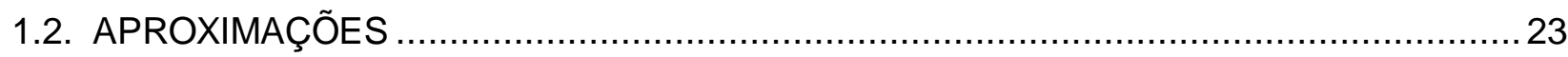

CAPÍTULO II - ANOp: CARACTERÍSTICAS E APLICAÇÕES...............................................43

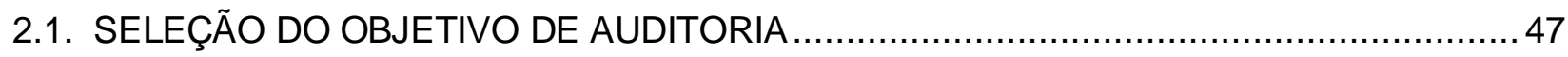

2.1.1. Integração do tema com planejamento estratégico............................................. 48

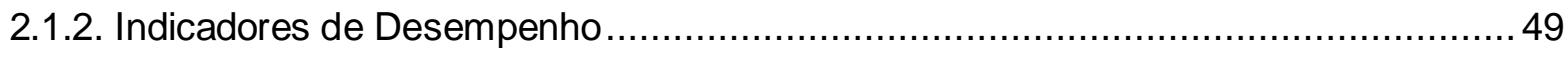

2.1.2.1. Índice de transparência da administração pública: ............................................ 49

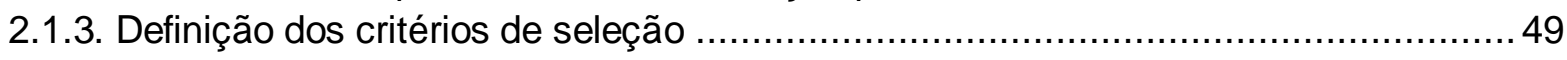

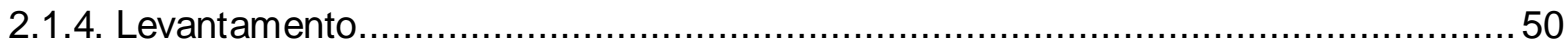

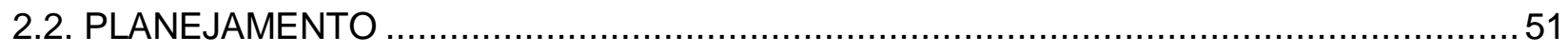

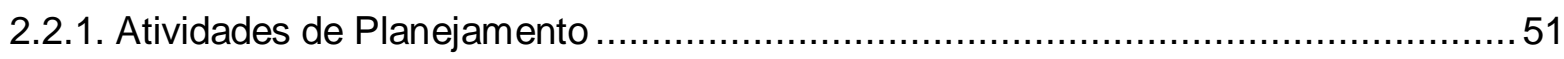

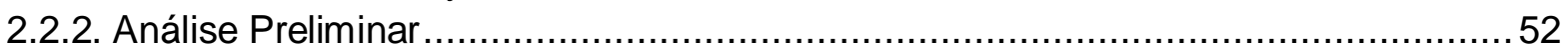

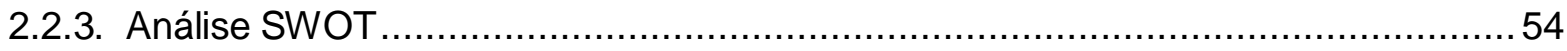

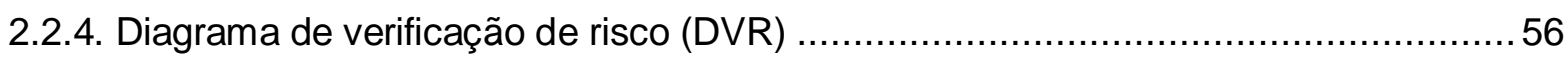

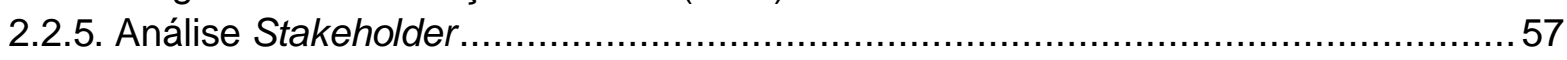

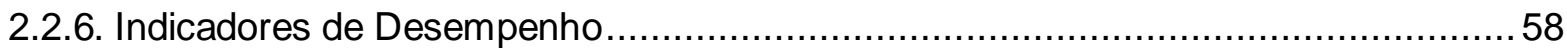

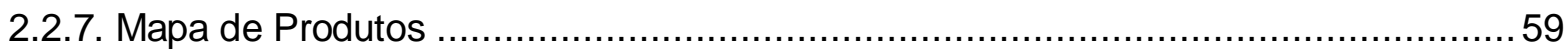

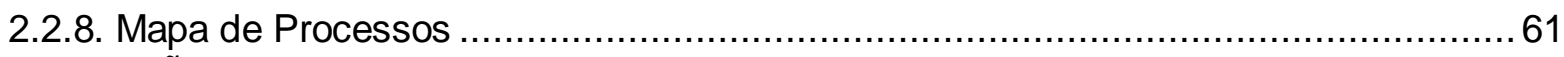

2.3. DEFINIÇÃO DO OBJETO E DO ESCOPO DA AUDITORIA ….....................................

2.4. ESPECIFICAÇÃO DOS CRITÉRIOS DE AUDITORIA E ELABORAÇÃO DA MATRIZ DE

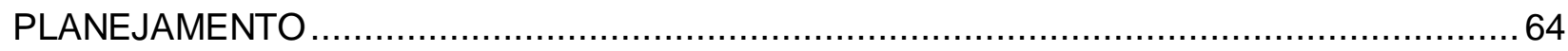

2.5. EXECUÇÃO

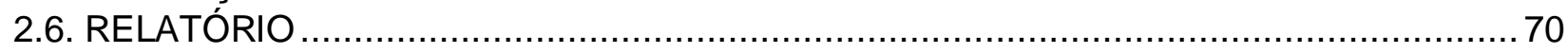

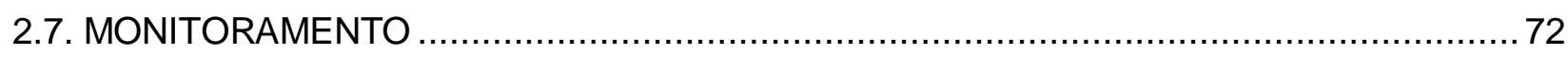

CAPÍTULO III - ANOP: UMA AVALIAÇÃO DO PROCESSO DE IMPLEMENTAÇÃO NO TCU C.1.

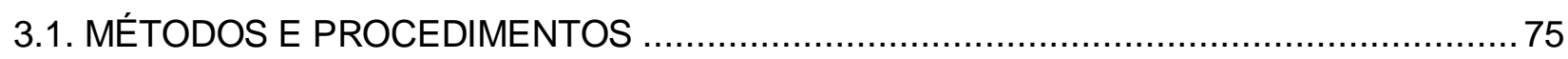

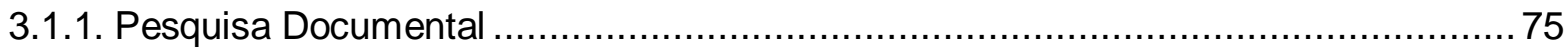

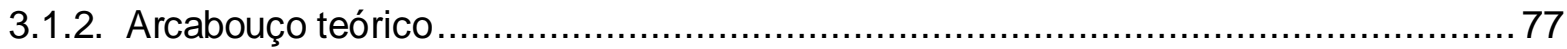

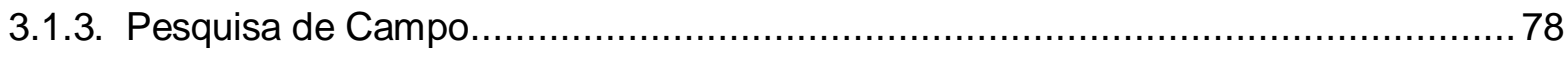

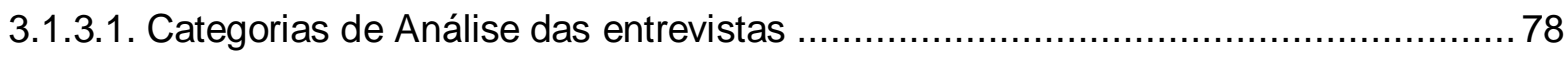

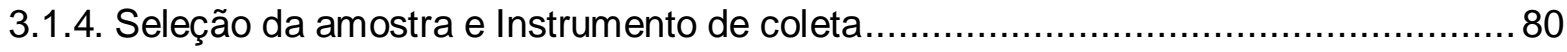

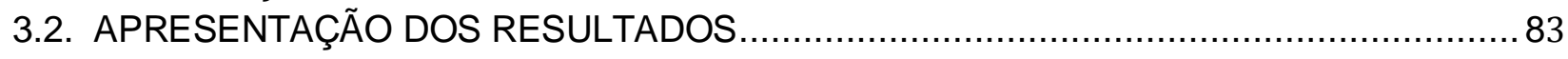

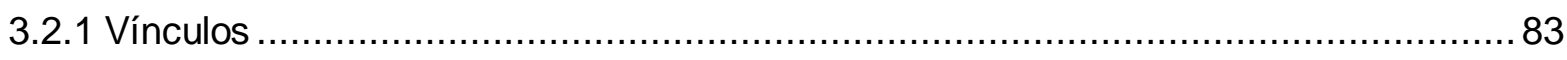




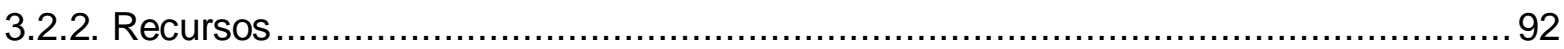

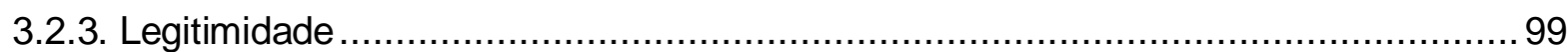

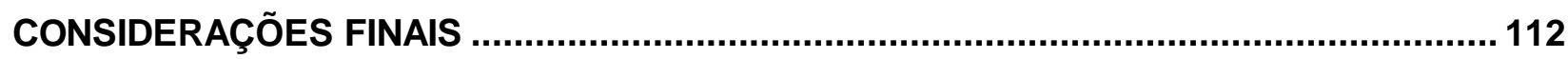

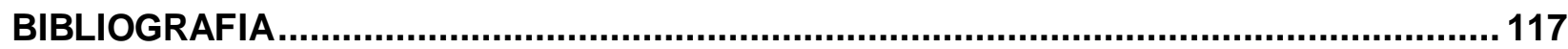




\section{INTRODUÇÃO}

A complexidade da sociedade moderna trouxe novas reflexões sobre o papel da Administração Pública. As variáveis eficiência, eficácia, economicidade e mais recentemente efetividade foram introduzidas gradualmente no setor público com a expectativa de obter respostas mais confiáveis aos seus problemas sociais, econômicos e políticos.

Questões como a democratização do Estado, a descentralização da Administração e a profissionalização da burocracia surgiram em resposta à necessidade de extensão, atendimento e reconhecimento de direitos e demandas emergentes. A construção do conceito da Nova Gestão Pública transcendeu o uso ótimo dos recursos e padrões de qualidade e se estendeu à verificação e mensuração dos seus impactos.

Por meio da racionalização de procedimentos e do aumento da responsabilidade dos burocratas, "a Nova Gestão Pública propõem maior flexibilidade da Administração Pública e o aumento da accountability ou responsabilização governamental” (BRASIL, 1997. p.11). Novas práticas de monitoramento e avaliação de políticas públicas estão sendo desenvolvidas no intuito de sustentar a Gestão Pública com informações concretas e que sejam capazes de alavancar a eficiência, eficácia e efetividade de seus programas.

Nota-se que a análise sistemática e objetiva dos resultados alcançados por um projeto, programa ou política vem sendo desenvolvida em alguns países por Entidades de Fiscalização Superior- EFS. Essas Entidades de Controle com competência de auditar a execução de gastos públicos vivenciam também a função de avaliar a relevância, coerência e sustentabilidade dos programas.

Este trabalho aborda o processo de institucionalização do conjunto de práticas avaliativas denominado Auditoria Operacional (ANOp) no Tribunal de Contas da União (TCU) verificando como esse processo contribuiu para a construção e consolidação da função de avaliador de políticas públicas do TCU, tendo como base os seguintes eixos: a) a motivação para o desenvolvimento da ANOp no âmbito do TCU; b) as mudanças ocorridas no TCU durante o processo de implementação da ANOp; c) a verificação dos resultados alcançados pelo TCU com a aplicação da ANOp. 
Esta tendência das Instituições de Controle Externo atuarem como agentes de avaliação e planejamento advém, segundo alguns autores, de um movimento que favorece práticas de controle $^{1}$, promoção de autonomia, valorização do desempenho e da autoresponsabilização realizadas por Agências Internacionais e Organizações Multilaterais (STRATHERN, 2000 apud WATERLOO², 2000).

Este processo de homogeneização de práticas (isomorfismo) experimentado também pelos países membros da Organização Internacional de Entidades Fiscalizadoras Superiores (INTOSAI) será abordada no presente trabalho à luz da Teoria do Neoinstitucionalismo, que enfatiza o papel desempenhado por estruturas institucionais na imposição de elementos de ordem em um mundo potencialmente imperfeito (MARCH \& OLSEN, 2008)

O presente trabalho foi organizado em três capítulos que traçam os conceitos básicos, a trajetória de institucionalização e a perspectiva de aplicação de práticas avaliativas por Entidades de Fiscalização Superior no âmbito brasileiro.

O primeiro Capítulo, "Avaliação e Auditoria: conceitos que se afastam e práticas que se aproximam", apresenta diferenças entre os termos a partir de suas origens e evolução dos seus conceitos. Por intermédio da contextualização e mapeamento da evolução histórica do planejamento e controle no Brasil, evidencia-se a aproximação de ambas as práticas, em decorrência da influência internacional e do novo entendimento do papel da gestão pública e controle.

O Capítulo seguinte intitulado "Auditoria Operacional: características e aplicações", traz detalhamentos sobre a ferramenta ANOp mediante uma breve releitura de manuais internos do TCU, tratando os métodos e técnicas empregados durante a execução desta atividade. São elencadas as etapas de trabalho inerentes ao ciclo de auditoria operacional, desde a escolha do tema, planejamento, execução e elaboração do relatório, até o monitoramento das deliberações resultantes da apreciação dos relatórios de auditoria.

\footnotetext{
${ }^{1}$ Segundo relatório da OCDE, a credibilidade das políticas públicas e uma administração limpa são fatores cruciais para alcançar o desenvolvimento sustentável e inclusivo e para manter a confiança no governo. O TCU ajuda a garantir que o governo é responsabilizado para a sua gestão de recursos públicos e que o dinheiro dos contribuintes é utilizado para a sua pretendida propósitos, de forma econômica, eficiente e eficaz. Trabalho TCU também tem um efeito preventivo: os funcionários públicos se comportam de forma diferente se eles sabem de suas ações pode ser avaliadas externamente por uma instituição independente e competente. Esses papéis são particularmente significativo no Brasil, dada a preocupação com a eficiência da despesa e corrupção no setor público.

${ }^{2}$ STRATHERN, M. 2000 introduction: new accountabilities. In: M. STRATHERN (ed.) Audit Cultures: anthropological studies in accountability, ethics, and the academy. London: New York, Routledge, p.1-18.
} 
O terceiro Capítulo "Auditoria Operacional: uma avaliação de sua implementação no TCU", traz reflexões sobre entrevistas realizadas com os próprios auditores do Tribunal, funcionários que trabalham com esta ferramenta e/ou contribuíram para sua construção. Inferiram-se sobre os ganhos atuais, perspectivas de aplicação e extensão da avaliação no âmbito do Governo Federal para além dos limites das Instituições de Controle. Inicia-se com a descrição dos métodos e procedimentos utilizados na revisão documental, no levantamento bibliográfico e na pesquisa de campo e, em seguida, compara os resultados de observação empírica sobre a institucionalização da ANoP em dois períodos:

- $\quad$ Período 1 - Institucionalização da ANoP entre o período de 1982 até 2003;

- Período 2 - Institucionalização da ANoP entre o período de 2004 até 2014

Nas considerações finais do trabalho identificam-se limites da presente pesquisa e lacunas a serem exploradas por estudos futuros. 


\section{CAPÍTULO I - AVALIAÇÃO E AUDITORIA: CONCEITOS QUE SE AFASTAM E PRÁTICAS QUE SE APROXIMAM}

A Nova Gestão Pública orientada no sentido de incrementar a eficácia e eficiência da administração vem perseguindo o maior entendimento dos seus mecanismos de ação e controle. São variadas e numerosas as iniciativas do governo de aprimoramento dos canais e mecanismos de informação.

Seguindo esta linha de aperfeiçoamento das fontes de dados, observa-se que as Entidades de Fiscalização Superior ${ }^{3}$ - EFS, embora, tradicionalmente, órgãos que auxiliam o legislativo no controle externo da gestão pública verificando a conformidade e legalidade dos atos de quem lida com valor público, vem expandido sua atuação também para verificação do desempenho de atividades, projetos, programas, políticas e órgãos governamentais.

Essa perspectiva participativa e democrática resulta na aproximação dos termos avaliar e auditar, que na literatura possuem origens e aplicações distintas. O exame de aspectos abstratos como efetividade, contribuiu de certa maneira para essa interposição de competências. A atuação combinada, porém descoordenada dos órgãos de controle tem levado ao crescente processo de judicialização das políticas públicas e gerado ambiente de incerteza (Agenda Nacional de Gestão Publica).

O desafio maior, nesse sentido, seria a ampliação da compreensão sobre a atuação dos órgãos de controle com o intuito de evitar a excessiva judicialização e diminuir práticas obsoletas, ineficientes e caras.

\subsection{AFASTAMENTOS}

Etimologicamente, o termo avaliação vem do latim valere, uma derivação da palavra valeo que significa ter o valor. Já auditoria, apesar da origem latina audire (ouvir), é explicada pela palavra inglesa audit que significa examinar. Para Worthen (2004, p. 89), "a Avaliação é a

\footnotetext{
3 Tradução do termo Supreme Audit Institution - SAI. São instituições nacionais responsáveis pela auditoria governamental de receitas e gastos. Os seus mandatos legais, relações de subordinação e eficácia variam, refletindo diferentes sistemas de o governo e políticas governamentais, mas seu objetivo principal é fiscalizar a gestão dos fundos públicos e a qualidade e credibilidade dos dados contábeis dos governos. (http://www1.worldbank.org/prem/PREMNotes/premnote59.pdf).
} 
identificação, esclarecimento e aplicação de critérios defensáveis para determinar valor (mérito), qualidade, utilidade e efetividade."

A prática de avaliar é inerente ao ser humano, constantemente, mantém julgamento quanto às causas e efeitos de diversos acontecimentos em nosso dia a dia. Não é preciso o conhecimento técnico para se avaliar os riscos de nossas ações. A avaliação pode ser formal ou informal.

A avaliação informal ocorre sempre que uma pessoa opta, por uma entre várias alternativas existentes sem antes ter coletado evidência formal do mérito relativo dessas alternativas. Nas avaliações de aprendizado, por exemplo, a informalidade pode concretizar-se na: interferências da chefia da escola no trabalho pedagógico do professor, no poder da hierarquia dentro do grupo de professores, crenças sobre alunos-padrão divulgadas entre professores, imagens e expectativas do professor com relação ao comportamento esperado de seus alunos.

Em entrevista ao Ministério da Educação, a professora da Faculdade de Educação e do Programa de Pós-graduação em Educação da Universidade de Brasília, pedagoga Benigna Maria de Freitas Villas Boas, declarou ${ }^{4}$ :

“...que outro tipo de avaliação muito frequente: é aquela que se dá pela interação de alunos com professores, com os demais educadores que atuam na escola e até mesmo çom os próprios alunos, em todos os momentos e espaços do trabalho escolar. É chamada de avaliação informal. Ela é importante porque dá chances ao professor de conhecer mais amplamente cada aluno: suas necessidades, seus interesses, suas capacidades. Quando um aluno mostra ao professor como está realizando uma tarefa ou Ihe pede ajuda, a interação que ocorre nesse momento é uma prática avaliativa, isto é, o professor tem a oportunidade de acompanhar e conhecer o que ele já aprendeu e o que ainda não aprendeu. Quando circula pela sala de aula observando os alunos trabalharem, o professor também está analisando, isto é, avaliando o trabalho de cada um. São momentos valiosos para a avaliação." (VILLAS BOAS, 2004.)

Há ainda entendimentos que a avaliação é uma via para racionalização, segundo Cohen, que dialoga entre a mensuração de outcomes ${ }^{5}$ e outputs ${ }^{6}$. O foco é a constatação de êxito (do

\footnotetext{
${ }^{4}$ http://portaldoprofessor.mec.gov.br/noticias.html?idCategoria=8\&idEdicao=12

${ }^{5}$ Out.come: $\mathrm{n}$ resultado, efeito, consequência. http://michaelis.uol.com.br

${ }^{6}$ Out.put: $n 1$ produção. 2 Econ output: produto.. http://michaelis.uol.com.br
} 
mérito, da utilidade ou da efetividade) e o levantamento de prováveis falhas no sentido de redirecionamento de ações.

Já a Auditoria, conforme definição de Araújo (2001), "um conjunto de procedimentos aplicados sobre determinadas ações, objetivando verificar se elas foram ou são realizadas em conformidade com normas, regras, orçamentos e objetivos." A auditoria confronta a condição situação encontrada - com o critério- situação que deve ser.

A auditoria moderna nasceu das Ciências Contábeis padronizada e controlada com a pretensão de constatar a exatidão de seus instrumentos econômicos e financeiros. Em geral, é uma comparação ou verificação de conformidade. A Auditoria contábil possui diversas tipologias, segundo alguns autores as principais são: financeira, fiscal e orçamentária.

O estudo da conformidade é a busca da Verdade. De acordo com Aristóteles "Dizer que é, o que é e dizer que não é o que não é, eis a verdade". Filosoficamente, a verdade pode ser definida como a relação de conformidade entre a ideia e o objeto. Nesse sentido, diferente da Auditoria, os processos avaliativos, mesmo que formais, não buscam a verdade, mas a ponderação dos valores entre supostas alternativas.

Algumas instituições de Fiscalização e Controle, por outro lado, entendem que tanto a formalidade, quanto à conformidade fazem parte dos processos tanto de auditoria, quanto da avaliação:

A Avaliação da conformidade é um processo sistematizado, com regras prédefinidas e permanente acompanhamento, para garantir adequado grau de confiança de um produto, processo ou serviço, ou ainda um profissional, aos requisitos pré-estabelecidos em normas ou regulamentos. ${ }^{7}$

A Auditoria de conformidade tem por objetivo o exame da legalidade e legitimidade dos atos de gestão em relação a padrões normativos expressos em normas técnicas ou jurídicas e regulamentos aplicáveis, bem como em relação a disposições de cláusulas de contratos, convênios, acordos, ajustes e instrumentos congêneres. ${ }^{8}$

A auditoria é utilizada para chancelar e assegurar o cumprimento de modelos de qualidade de processos e procedimentos, fornecendo maior credibilidade no cumprimento dos controles internos (ou externos). Sua principal finalidade é averiguação das normas, sem a

\footnotetext{
7 INMETRO/CONMETRO, 2002.

${ }^{8}$ TCU/GLOSSÁRIO
} 
garantia do êxito das atividades. A Norma Brasileira de Contabilidade - NBC ${ }^{9}$ TA 200 entende que o objetivo da auditoria é aumentar o grau de confiança nas demonstrações contábeis por parte dos usuários.

Já a avaliação de acordo com Fetterman apud Worthen (2004) é utilizada para empoderar, emancipar e esclarecer o stakeholder ${ }^{10}$ por meio do fornecimento de informações. Exemplos de usos de avaliação:

- Na educação:

- Julgar a qualidade dos currículos escolares em áreas específicas ${ }^{11}$;

- Atender as demandas de relatórios sobre a eficiência dos programas escolares dos órgãos externos de financiamento que os sustentam ${ }^{12}$.

- Em setores públicos:

- Decidir se um programa de desenvolvimento urbano vai ou não ser implantado ${ }^{13}$;

- Determinar o valor de um programa de qualificação profissional ${ }^{14}$;

- Determinar o impacto de um programa de redução de penas prisionais sobre a reincidência ${ }^{15}$.

- Comércio e indústria:

- Melhorar um produto comercial;

- Julgar a eficiência de um programa de treinamento empresarial;

\footnotetext{
${ }^{9}$ As Normas Brasileiras de Contabilidade são regras de conduta profissional e procedimentos técnicos, estabelecido pelo Conselho Federal de Contabilidade e devem ser observados quando da realização dos trabalhos previstos na Resolução CFC $n^{\circ}$ 560/83, de 28 de outubro de 1983, em consonância com os Princípios Fundamentais de Contabilidade.

${ }_{11}^{10}$ Stakeholder - parte interessada ou interveniente. http://www.oxforddictionaries.com

11 Políticas de currículo e avaliação e políticas docentes. Cad. Pesqui. vol. 42 no.147 São Paulo Dec. 2012. Elba Siqueira De Sá Barretto. http://www.scielo.br.

Políticas de avaliação em larga escala na educação básica: do controle de resultados à intervenção nos processos de operacionalização do ensino. Flávia Obino Corrêa Werlehttp://www.scielo.br.

12 A INTERVENÇÃO DO FINANCIAMENTO NAS POLITICAS PÚBLICAS DOS SISTEMAS DE EDUCAÇÃO FEDERADOS. DA SILVEIRA, Darmem $\quad$ Lucia http://www.anpae.org.br/simposio26/1comunicacoes/CarmemLuciaAlbrecht-ComunicacaoOral-int.pdf

${ }_{13}$ Martin Ravallion, The Mystery of the Vanishing Benefits: Ms. Speedy Analyst's Introduction to Evaluation, Documento de trabalho de estudo de políticas No 2153, 1999.

${ }_{11}^{14}$ CSIP Quick Guide Evaluation 2006. www.csip.org.uk/evaluation

${ }^{15}$ Plano Nacional de politica Criminal e Penitenciaria. Aprovado na 372a reunião ordinária do Conselho Nacional de Política Criminal e Penitenciária (CNPCP), em 26/04/2011. 
- Avaliar novas iniciativas administrativas, como Marketing.

Exemplos do uso da auditoria, conforme Resolução CFC ${ }^{16}$ nํ. 1.023 (1) de 15 de abril de 2005, NBC P 1.8:

\subsubsection{Necessidade de Uso de Trabalho de Especialista}

1.8.2.1. Durante a auditoria, o auditor independente pode necessitar obter, em conjunto com a entidade auditada ou de forma independente, evidências para dar suporte às suas conclusões. Exemplos dessas evidências, na forma de relatórios, opiniões ou declarações de especialistas são:

a) avaliações de certos tipos de ativos, como, por exemplo, terrenos e edificações, máquinas e equipamentos, obras de arte e pedras preciosas;

b) determinação de quantidades ou condições físicas de ativos, como, por exemplo, minerais estocados, jazidas e reservas de petróleo, vida útil remanescente de máquinas e equipamentos;

c) determinação de montantes que requeiram técnicas ou métodos especializados, como, por exemplo, avaliações atuariais;

d) medição do estágio de trabalhos completados ou a completar em contratos em andamento;

e) interpretações de leis, de contratos, de estatutos ou de outros regulamentos. (RESOLUÇÃO CFC, 2005).

O Objeto na Auditoria é a investigação de todos os elementos de controle da instituição, já para Avaliação, não há limitação ou restrição do seu escopo, podendo, inclusive, dialogar com mecanismos de controle. Para WORTHEN (2004, p. 78) o objeto da avaliação é qualquer coisa que esteja sendo avaliada.

Outra diferença importante gira em torno da uniformidade de suas técnicas. A padronização dos instrumentos de trabalhos valida os relatórios fornecidos pelas auditorias. Suas recomendações se sustentam em entendimentos metodológicos e técnicos testados previamente e compartilhados por diversas organizações. As ferramentas empregadas são, portanto, comuns a um grupo de interesse. Seus indicadores fazem leituras semelhantes em diversos cenários visando o entendimento universal.

\footnotetext{
${ }^{16}$ Conselho Federal de Contabilidade
} 
A avaliação, por sua vez, não se subordina a nenhuma norma específica de conduta, pelo contrário, procura utilizar ferramentas e técnicas que se adaptam melhor a demanda do stakeholder e do objeto de estudo (evaluaed). Isso não interfere em características incomuns aos dois termos, como a sistematização, investigação e observação apenas proporciona maior flexibilidade para avaliação.

A avaliação possui caráter formativo e somativo. A avaliação formativa fornece informações avaliatórias, ou seja, informações úteis para a melhoria do objeto, por outro lado, a somativa (com identidade pública) dá aos responsáveis pela tomada de decisões e os clientes em potenciais, julgamentos do mérito em relação aos critérios pré-estabelecidos.

O público a que se endereçam também é diferente, pois a Formativa se endereça a equipe gestora, fornecendo informações para o desenvolvimento e realinhamento das atividades; e a Somativa aos consumidores potenciais do serviço, pretendendo demonstrar se aquele objeto deve ter continuidade ou não, se deve ser ampliado ou não, etc.

A utilidade da avaliação formativa gira em torno de sua tempestividade e controle. Controle no sentido de que suas sugestões de melhoria operem sobre variáveis que os administradores possuam domínio e autoridade, e ainda, que sejam oportunas, pois, se tardarem, as melhorias serão inúteis. Este é um ponto muito importante da avaliação, sua proximidade com o Executor e sua capacidade de fornecer inputs ${ }^{17}$ na tomada de decisões.

São funções do Administrador: planejar, organizar, dirigir e controlar. De acordo com as leituras de Peter Drucker ${ }^{18}$, o controle se exerce por meio do monitoramento e da avaliação de atividades garantindo a execução do planejamento e a correção dos desvios. A Teoria da Administração demonstra que os papéis informacional e decisional estão intrinsecamente interligados e esta definição holística da ciência social é fundamental para compreendermos a evolução de conceitos como: o controle e planejamento.

Conforme o ramo de atuação da instituição a auditoria pode ser: pública (governamental) ou privada. A Auditoria Pública no Brasil enfrenta, atualmente, problemas como:

- Controle excessivamente engessado:

\footnotetext{
17 In.puts - n 1 quantidade que entra, quantidade ou força que é consumida. 2 absorção. 3 com entrada, insumo. 4 Comp. entrada de dados. vt Comp. alimentar 0 computador com informação. http://michaelis.uol.com.br/moderno/ingles/definicao/ingles-portugues/input\%20_459510.html

${ }_{18}$ Peter Ferdinand Drucker foi um professor e escritor austríaco considerado o pai da administração moderna. Disponível em: <http://exame.abril.com.br/revista-exame/edicoes/0856/noticias/ele-vai-fazer-falta-m0078612>
} 
A administração pública se encontra engessada pela rigidez do controle exercido pelos órgãos competentes. Ao invés de se tornar mais flexível e resiliente diante dos desafios contemporâneos, as instituições públicas estão se tornando mais rígidas e dissociadas do contexto atual. As origens dos problemas são variadas, mas o fato é que os gestores estão cada vez mais impotentes para reagir à multiplicidade e heterogeneidade de controles aos quais estão submetidos. (Agenda Nacional de Gestão Pública)

- Formalismo x discricionariedade:

Oscilação viciosa entre o formalismo rígido e o discricionarismo irrestrito.

- A judicialização da gestão.

Todos estes pontos foram problemas tratados no documento Agenda Nacional de Gestão Pública, que objetivou promover diálogos entre a sociedade civil, empresários e estado, sobre a modernização da gestão pública e apresentar propostas de melhoria para a qualidade do serviço público no Brasil em 2009. ${ }^{19}$ Como soluções foram identificados o fomento a responsividade das autoridades governamentais, a preocupação com os custos de oportunidade (value for money) e a promoção de uma nova postura dos órgãos de controle a fim de que sejam aliados da "nova cultura administrativa".

As discussões sobre a postura dos órgãos de controle como aliados da Nova Gestão Publica giram em torno de argumentos que pretendem criar além da auditoria tradicional (de conformidade), a auditoria de desempenho, sustentando e legitimando a função de avaliação por Entidades de Fiscalização Superior - EFS

De acordo com Barzelay, o termo "auditoria de desempenho" é normalmente utilizado para demarcar a distinção entre esse tipo de atividade de revisão governamental: a auditoria tradicional de um lado e a avaliação de programas de outro.

No Brasil, segundo SILVA (2002) apud HEDLER ${ }^{20}$, embora a avaliação apresente indicadores setoriais diferenciados conforme a área de ação pública e política (educação, segurança, saúde, etc.), a mesma apresenta como característica a descontinuidade e dispersão das evidências e dos resultados pouco documentados e sistematizados.

\footnotetext{
${ }^{19} \mathrm{http}: / /$ www.sae.gov.br/site/?p=987

20 Silva, P.L.B. (2002a). A Avaliação de programas públicos: Reflexões sobre a experiência brasileira. Relatório técnico. Brasília: IPEA
} 
Essa percepção de fragilidade dos processos avaliativos realizados pelos atores públicos do executivo corrobora para a dúbia função de avaliação e auditoria, que tendem a se aproximar devido:

- $\quad$ Prioridade e legitimidade crescentes de avaliação interna;

- Uso mais frequente de métodos qualitativos;

- Uma grande mudança no sentido de combinar métodos quantitativos e qualitativos;

teorias; Introdução e desenvolvimento de instrumentos guiados por

- Modificações das estratégias de avaliação e auditoria para acomodar as tendências crescentes de descentralização do governo e delegação de responsabilidades a estados e municípios. (Gardênia da Silva (Abbad) ${ }^{21}$

Alguns autores Chelimsky 1985; Rist 1989 apud Barzelay reconhecem como uma forma de avaliação a Auditoria de Desempenho.

Avaliação é uma ferramenta que contribui para integrar as atividades do ciclo de gestão pública. Envolve tanto julgamento como atribuição de valor e mensuração. Não é tarefa neutra, mas comprometida com princípios e seus critérios. Requer uma cultura, uma disciplina intelectual e uma familiaridade prática, amparadas em valores. Deve estar presente, como componente estratégico, desde o planejamento e formulação de uma intervenção, sua implementação (os consequentes ajustes a serem adotados) até as decisões sobre sua manutenção, aperfeiçoamento, mudança de rumo ou interrupção, indo até o controle. $\left(R \cup A^{22}, 2003\right)$.

O Tribunal de Contas da União - TCU orientando sua ação por meio do conceito acima, publicou diversos trabalhos manifestando a junção de qualidades anteriormente endereçadas individualmente a Avaliação ou a Auditoria. O julgamento de conformidade e mensuração de valor são partes de um processo único que ressalta e valida o viés cultural do avaliador, bem como incorpora para Auditoria ao mesmo tempo o papel da Avaliação formativa e somativa.

\footnotetext{
${ }^{21}$ Abbad, Gardênia da Silva. Avaliação de Programas Origens, avanços e tendências.2012

${ }^{22}$ RUA, Maria das Graças. Avaliação de Políticas Programas e Projetos: Notas Introdutórias. 2003.
} 
Com a adoção da análise de processos que visam um entendimento multidimensional dos estágios e subestágios das políticas públicas, as distâncias se estreitaram. Essa mudança na forma de analisar modificou a perspectiva que antes se orientava pelo formalismos.

\subsection{APROXIMAÇÕES}

A história do controle no Brasil remonta ao período colonial em que mudanças referentes às instituições e suas atribuições aconteceram durante a Monarquia, como a criação do Tesouro, previsão dos primeiros orçamentos e balanços gerais (Constituição de 1824). A ideia de criação de um Tribunal de Contas surgiu, pela primeira vez no Brasil, em 1826. Porém, sua institucionalização somente se materializou com a Constituição de 1891.

Com a revolução científica iniciada na Europa no século XVII, inspirada pelas ciências naturais, surge à avaliação de programas. Seus primeiros registros são na área da saúde pública criando um processo de retroalimentação sistêmico inspirado na necessidade de evitar as epidemias e na consolidação do Direito a Saúde. Já a Auditoria, segundo documentos históricos tem sua origem a partir da criação de procedimentos contábeis-financeiros datados de 1581 pela Associação de Contadores em Veneza.

Com a Revolução Industrial e com o incremento da escala de produção, a necessidade das organizações em gerir e monitorar esforços com fins específicos fomentou a criação de uma disciplina capaz de organizar técnicas de sistematização e mensuração de processos produtivos. Alguns conceitos e práticas empregados e difundidos no campo privado, com o tempo, migraram e sofreram adaptações no meio público. A Administração Pública é uma subdisciplina da Administração que estuda métodos administrativos os quais proporcionam maior racionalidade às ações do Estado.

Os modelos de Administração Pública empregados no Brasil podem ser divididos em três:

1. Administração Patrimonialista (Império) - fase marcada pelo nepotismo e corrupção no serviço público. Não havia separação do patrimônio público e da monarquia. Os cargos políticos eram ocupados por nobres nomeados;

2. Administração Pública Burocrática (Estado Novo - Getúlio Vargas) - "Modelo Racional", objetivou o combate à corrupção e o nepotismo. Iniciou o processo de 
profissionalização do serviço público, estabelecendo carreiras, hierarquia funcional e formalismo;

3. Gerencialismo (atual) - O aperfeiçoamento da Administração Pública mediante aplicação dos conceitos de eficiência, efetividade e eficácia; e a busca da otimização e a expansão dos serviços públicos.

Quadro 1. Histórico do Planejamento e Gestão Publica no Brasil.

\begin{tabular}{|c|c|c|c|c|c|}
\hline Céclas econberices & Padrico de Estado & $\begin{array}{c}\text { Contexto } \\
\text { econdmico-estrutural }\end{array}$ & 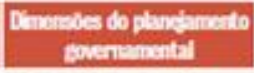 & $\begin{array}{c}\text { Costato } \\
\text { polatico-inntitucional }\end{array}$ & $\begin{array}{l}\text { Dimenaces da } \\
\text { cestivo piblica }\end{array}$ \\
\hline $\begin{array}{l}\text { 1889-1960: Prmera } \\
\text { Republca - deservininto } \\
\text { para bra }\end{array}$ & $\begin{array}{l}\text { Domintria } \\
\text { lberstolgraica }\end{array}$ & $\begin{array}{l}\text { Econonia cofecra votada para } \\
\text { o otsrior }\end{array}$ & 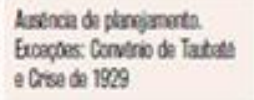 & $\begin{array}{l}\text { Uortgem do sarto } \\
\text { estatl Hurocrtbos }\end{array}$ & Patrinoridsta \\
\hline $\begin{array}{l}\text { 1363-1965: Era Gotilo } \\
\text { Kayss - nacons- } \\
\text { dasencinertismb }\end{array}$ & $\begin{array}{l}\text { Dominancia nesional- } \\
\text { deseovidinertista }\end{array}$ & 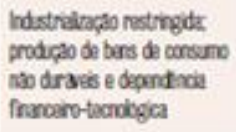 & 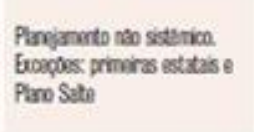 & $\begin{array}{l}\text { Mertagen do sistena } \\
\text { corpontista }\end{array}$ & $\begin{array}{l}\text { Petritorid burourtica } \\
\text { - Dasp (1968) }\end{array}$ \\
\hline $\begin{array}{l}\text { 1966-1964: Era } \\
\text { Jecoliro Ketitschk - } \\
\text { ittmacionaluapa exnomiza }\end{array}$ & $\begin{array}{l}\text { Dominanci } \\
\text { estatablenocrtica }\end{array}$ & 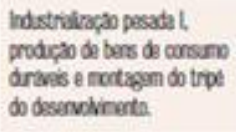 & 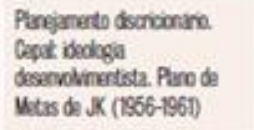 & $\begin{array}{l}\text { Aconodscito } 8 \text { ctite do } \\
\text { nodkh. }\end{array}$ & Patriturid furocratica \\
\hline $\begin{array}{l}\text { 1964-1979. Regre nittr - } \\
\text { estdivar30 eccontrica }\end{array}$ & $\begin{array}{l}\text { Dominaria } \\
\text { estahatontana }\end{array}$ & 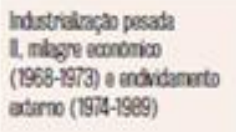 & 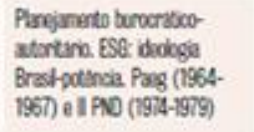 & $\begin{array}{l}\text { Conscidypa } \\
\text { intlucond-utontina }\end{array}$ & $\begin{array}{l}\text { Petrinoris-tyrocritca - } \\
\text { Pag (1967) }\end{array}$ \\
\hline $\begin{array}{l}\text { 1980-A9e9: } \\
\text { Redenocrkincta - crise } \\
\text { do desenovinertisno }\end{array}$ & $\begin{array}{l}\text { Domintode } \\
\text { lberd-derocitica }\end{array}$ & 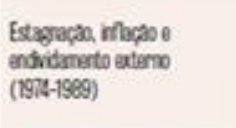 & 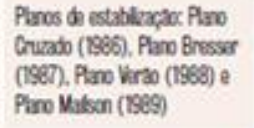 & 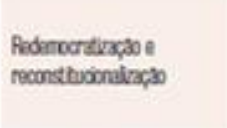 & $\begin{array}{l}\text { Petrimbial-brocratica } \\
-\alpha / 88\end{array}$ \\
\hline 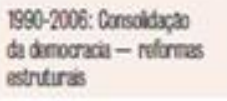 & $\begin{array}{l}\text { Dominthols } \\
\text { lberd-donocrstas }\end{array}$ & 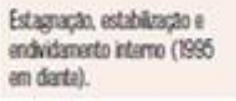 & 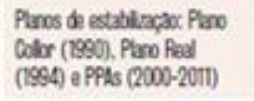 & 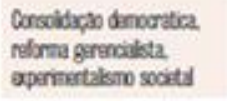 & 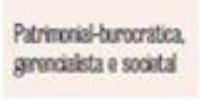 \\
\hline
\end{tabular}

Fonte: Extraído de Revista Desafios do desenvolvimento/IPEA 2011. Ano 8. Edição 69 - 21/11/2011

Para os autores, Pérsio e José Celso mencionadas na matéria Perspectiva- A estratégia do Planejamento nacional da Revista Desafios do Desenvolvimento do IPEA, o país passou por três fases de planejamento: auge (décadas de 1940 a 1970), declínio (décadas de 1980 e 1990) e retomada (primeira década do século XXI) da função planejamento.

As políticas de intervenção do Estado na economia com a finalidade de promover seu desenvolvimento constituíram um marco no aprofundamento do planejamento governamental. Durante este período, foram criadas políticas de industrialização e capacitação técnica que contribuíram para a hegemonia do Poder Executivo. 
Conforme a CEPAL 23 "A concentração do poder nas mãos de um Executivo dotado de uma tecnoburocracia competente contribuiu para que a intervenção do Estado (apoiada na continuidade de um processo de planejamento) se estendesse a praticamente todos os setores da economia.".

Com o fim da Segunda Guerra em 1945, observou-se no mundo a passagem do Estado Liberal para Estado de Bem-Estar Social (Welfare) que, por meio da estatização, almejou atenuar a desigualdade social.

O Welfare State institucionalizou processos de tomadas de decisões materializando mecanismos democráticos no Estado de Direito. Vários países estavam vivenciando, com mais ou menos intensidade, situações similares e em razão do surgimento de interesses comuns, alguns Estados, invés de se reunirem em conferências internacionais de forma descontinuada, reconheceram a necessidade da constituição de organismos internacionais permanentes com a finalidade de estabelecer uma cooperação constante.

Se para os Estados Soberanos o respeito aos direitos e obrigações estabelecidos em acordos de cooperação internacional significavam o aumento do poder nacional, para os Estados mais fracos, o ingresso nos organismos internacionais significava legitimação e segurança. As principais características das organizações internacionais eram: a multilateralidade, a permanência e a institucionalização. Este período foi marcado pela propagação das organizações internacionais fruto das interdependências econômicas a nível mundial.

Segundo estudos de Fernanda Soares:

A partir disso, a trajetória ideológica das organizações internacionais repousaria em cinco momentos distintos após o ano de 1945: o funcionalismo (baseada no princípio de que as organizações internacionais deveriam servir os interesses da sociedade, descartando a preponderância da influência dos Estados); o desenvolvimentismo (em plena oposição leste/oeste, as organizações precisariam atuar mais incisivamente na manutenção da paz e da segurança); o transnacionalismo (a incapacidade dos países pobres em dispor de divisas, inviabilizando, portanto, as importações de bens de capital, induziria a oferecer condições para a instalação em solo pátrio de filiais de empresas estrangeiras, assim, as organizações presumiriam que essas empresas seriam os elementos dinâmicos do processo de desenvolvimento); o globalismo (identificaria a escassez de matéria-prima no planeta e os efeitos perversos, do ponto de vista ecológico, da busca incessante pelo crescimento econômico); a globalização (em razão de suas características, a globalização

${ }^{23}$ CEPAL COMISSÃO ECONÔMICA PARA A AMÉRICA LATINA E O CARIBE Escritório no Brasil Planejamento no Brasil: auge, declínio e caminhos para a reconstrução - Fernando Rezende. 
enfraqueceria o papel do Estado e das organizações em benefício das transnacionais privadas). (SOARES, 2010. Disponível em: <http://www.ambitojuridico.com.br/site/index.php?n_link=revista_artigos_leitura\&artigo_id=7195>)

Seguindo essa trajetória, foram fundados em 1945, United Nations (UN), League of Arab States, International Monetary Fund (INF) e World Bank. E em 1948, foi criado Organisation for European Economic Co-Operation.

A INTOSAI- Organização Internacional de Entidades Fiscalizadoras Superiores foi fundada em 1953 por 34 países (incluindo o Brasil) por iniciativa de Emilio Fernandez Camus, então Presidente da $\mathrm{SAl}^{24}$, de Cuba. É uma organização autônoma, formada por 190 países que possui status consultivo no Conselho Econômico e Social (ECOSOC) das Nações Unidas. Em seu primeiro ano de criação foram discutidos:

- O sistema de contabilidade pública como base da atividade de auditoria e controle dos Tribunais de Contas;

- O escopo de controle pré-auditoria na execução do orçamento nacional;

- A propriedade das instituições públicas estaduais e outros problemas decorrentes de seu controle;

- Os recursos naturais, sua avaliação e controle como uma parte da preservação da riqueza da nação e controle de bens culturais;

- A auditoria interna da administração com a finalidade de seu controle;

- O Tribunal de Contas como o consultor financeiro do Estado;

- A reconciliação da autonomia funcional dos tribunais de auditoria com as operações normais da administração;

- Os tribunais de auditoria como os representantes do povo, na sua demanda para o controle da administração;

- Os Tribunais de Contas e sua relação com o Poder Legislativo;

\footnotetext{
${ }^{24}$ Em inglês SAls, Supreme Audit Institutions, em português EFS, Entidades Fiscalizadoras Superiores, são órgãos que atuam com relativa independência no controle da regularidade das contas públicas, tendo sob sua responsabilidade a avaliação do funcionamento administrativo das diversas unidades componentes do aparelho estatal, de forma a auxiliar os demais Poderes e a própria população.
} 
- A teoria do poder de controle dentro dos limites do direito constitucional moderno;

- A intervenção dos tribunais de auditoria no convite das propostas para a construção pública e aquisições da administração;

- As instituições autônomas como representantes do Estado na administração de serviços públicos;

- A atividade dos Tribunais de Contas no controle dos governos provinciais e municipais.

As EFS além de fiscalizarem se os governos estão alcançando os seus objetivos, como cumprir leis e sentenças judiciais, pretendem contribuir para a boa governança pública, aumentando a transparência, exigindo prestação de conta e identificando responsáveis. Os principais modelos empregados no mundo originaram-se da França e Inglaterra:

- Modelo britânico: Auditoria Geral

o Decisão unilateral por Auditor Geral;

o Foco em trabalhos de auditoria.

- Modelo francês: Tribunal de Contas

o Decisão colegiada por ministros/juízes;

o Foco em trabalhos de julgamento de contas.

O Brasil, como outros países, adotou o modelo francês de Tribunais de Contas, já o modelo britânico, foi mais difundido em países com colonização anglo-saxônica como: Canadá e EUA. Embora haja diferença no foco de trabalho dos dois modelos, observa-se uma convergência internacional no sentido de institucionalização de um único padrão, um processo isomórfico liderado pela INTOSA ${ }^{25}$.

No que concerne o nível internacional, a Auditoria de Desempenho foi elaborada sob a liderança da INTOSAI, que a incluiu em suas diretrizes de trabalho com o lema: "Experientia mutua omnibus prodest ${ }^{26}$.

\footnotetext{
${ }^{25}$ The International Organisation of Supreme Audit Institutions.www.intosai.org

${ }^{26}$ Mutual Experience Benefits All ou Compartilhamento da experiência beneficia a todos.
} 
A INTOSAI veio fornecendo padrões institucionalizados de auditoria com o intuito de fomentar o desenvolvimento e transferência de conhecimentos, melhora da auditoria governamental no mundo e reforço das capacidades de influência dos profissionais membros das $\mathrm{EFS}^{27}$ em seus respectivos países.

Alguns padrões internacionais foram determinados com as instituições das ISSAIS ${ }^{28}$ :

1. Nível 1 Princípios Fundamentais ISSAl 1 Declaração de Lima;

2. Nível 2 Pré-requisitos para o funcionamento das EFS (ISSAI 10, 11, 12, 20, $30 \mathrm{E}$ $40)^{29}$;

3. Nível 3 Princípios Fundamentais da Auditoria:

a. ISSAI 100 Princípios de Auditoria Governamental;

b. ISSAI 200 Princípios de Auditoria Financeira;

c. ISSAI 300 Princípios de Auditoria de Desempenho;

d. ISSAI 400 Princípios de Auditoria de Conformidade.

4. Nível 4 Diretrizes das Auditorias:

a. ISSAls 1000-2999 Diretrizes de Auditoria Financeira;

b. ISSAls 3000-3999 Diretrizes de Auditoria de Desempenho;

c. ISSAls 4000-4999 Diretrizes de Auditoria de Conformidade.

Após o primeiro Congresso de constituição do órgão, vários outros encontros foram estabelecidos até o momento da criação da Auditoria Integral precursora do conceito da auditoria desempenho: $2^{\circ}$ Congresso (Bélgica 1956), $3^{\circ}$ Congresso (Brasil 1959), $4^{\circ}$ Congresso (Áustria 1962), $5^{\circ}$ Congresso (Israel 1965), $6^{\circ}$ Congresso (Japão 1968), $7^{\circ}$ Congresso (Canadá 1971), $8^{\circ}$ Congresso (Espanha 1974).

\footnotetext{
${ }^{27}$ Em inglês SAls, Supreme Audit Institutions, em português EFS, Entidades Fiscalizadoras Superiores, são órgãos que atuam com relativa independência no controle da regularidade das contas públicas, tendo sob sua responsabilidade a avaliação do funcionamento administrativo das diversas unidades componentes do aparelho estatal, de forma a auxiliar os demais Poderes e a própria população, em última análise, no controle da legalidade e no combate ao desperdício.

${ }^{28}$ International Standards of Supreme Audit Institutions (ISSAI)

${ }^{29}$ ISSAI 10 Declaração do México, ISSAI 11 Diretrizes e boas praticas relacionadas a independência das EFS, ISSAI 12 Valores e benefícios das EFS, ISSAI 20 Princípios de Transparência e Accountability, ISSAI 30 Código de Ética e ISSAI 40 Qualidade a Auditoria.
} 
Segundo ARAÚJO (2001, p. 59), o marco inicial da auditoria de desempenho no mundo ocorreu em 1971 com a aprovação do conceito de "Auditoria Integral ${ }^{30 ", ~ n o ~ V I I ~ C o n g r e s s o ~}$ Intosai no Canadá. Seis anos mais tarde, no Congresso Mundial de Tribunais de Contas em Lima (Peru), foi recomendado a extensão dos exames para além da auditoria financeira a fim de alcançar o bem-estar dos países mediante a diminuição dos gastos inúteis e antieconômicos.

Três tipos de auditoria de desempenho são disseminados:

- Auditorias de eficiência (são as mais frequentes);

- Auditorias de capacidade de gerenciamento de desempenho;

- Auditorias de efetividade de programa.

Quadro 2: Principais tipos de auditoria de desempenho por país

\begin{tabular}{|c|c|c|c|c|}
\hline Tipo & Unidade de Análise & $\begin{array}{l}\text { Modalidade } \\
\text { de Revisão }\end{array}$ & Abrangência da Avaliação & Foco do Trabalho \\
\hline $\begin{array}{l}\text { Auditoria de } \\
\text { Eficiência }\end{array}$ & $\begin{array}{l}\text { Função } \\
\text { organizacional, } \\
\text { processo ou } \\
\text { elemento de } \\
\text { programa }\end{array}$ & Inspeção & $\begin{array}{l}\text { Aspectos de operações } \\
\text { governamentais ou de } \\
\text { terceiros }\end{array}$ & $\begin{array}{l}\text { Identificar oportunidades de } \\
\text { diminuir o custo orçamentário para } \\
\text { a produção dos resultados. }\end{array}$ \\
\hline $\begin{array}{l}\text { Auditoria de } \\
\text { Efetividade de } \\
\text { Programa }\end{array}$ & $\begin{array}{l}\text { Política, programa } \\
\text { ou elemento } \\
\text { significativo de } \\
\text { programa }\end{array}$ & Inspeção & $\begin{array}{l}\text { Aspectos selecionados do } \\
\text { desenho e da operação do } \\
\text { programa }\end{array}$ & $\begin{array}{l}\text { Avaliar o impacto das políticas } \\
\text { públicas, avaliar a efetividade do } \\
\text { programa }\end{array}$ \\
\hline $\begin{array}{l}\text { Auditoria de } \\
\text { Capacidade de } \\
\text { Gerenciamento } \\
\text { de Desempenho }\end{array}$ & Organização & Inspeção & $\begin{array}{l}\text { Aquela que afeta o } \\
\text { desempenho das funções } \\
\text { administrativas }\end{array}$ & $\begin{array}{l}\text { Avaliar a capacidade de atingir } \\
\text { objetivos genéricos de economia, } \\
\text { eficiência e eficácia }\end{array}$ \\
\hline $\begin{array}{l}\text { Auditoria de } \\
\text { Informações de }\end{array}$ & Organização & Auditoria & $\begin{array}{l}\text { Informação gerada pela } \\
\text { medida do desempenho/ }\end{array}$ & $\begin{array}{l}\text { Validar/atestar a precisão da } \\
\text { informação oferecida pela }\end{array}$ \\
\hline
\end{tabular}

Fonte: BARZELAY, Michael. Central Audit Institutions and Performance Auditing: A Comparative Analysis of Organizational Strategies in the OECD.

\footnotetext{
${ }^{30}$ Conforme IBRACON (Instituto dos Auditores Independentes do Brasil) a pesquisa ou exame crítico das atividades, operações e fatos econômicos, incluídos seus processos integrantes, realizados por um ente econômico qualquer que seja seu âmbito, mediante a utilização de um conjunto estruturado de processos que tem como objetivo a avaliação sistemática e permanente do ente econômico no seu universo, para obter e valorar evidência formar-se um julgamento sobre as asserções verificáveis e os achados obtidos, conforme a parâmetros e critérios existentes. Boletim do IBRACON - MAIO DE 1999 N. 252 por ANTONIO CARLOS PEDROSO DE SIQUEIRA.
} 
Quadro 3: Tipos de Auditoria de Desempenho

\begin{tabular}{|c|c|c|c|c|}
\hline & $\begin{array}{c}\text { Auditoria de } \\
\text { eficiência }\end{array}$ & $\begin{array}{c}\text { Auditoria de } \\
\text { efetividade de } \\
\text { programa }\end{array}$ & $\begin{array}{c}\text { Auditoria de } \\
\text { capacidade de } \\
\text { gerenciamento do } \\
\text { desempenho }\end{array}$ & $\begin{array}{c}\text { Auditoria de } \\
\text { informações } \\
\text { de } \\
\text { desempenho }\end{array}$ \\
\hline Austrália & V & V & V & \\
\hline Canadá & V & & V & \\
\hline Finlândia & V & & V & V \\
\hline França & V & V & & \\
\hline Alemanha & V & $\mathrm{V}$ & $\mathrm{V}$ & \\
\hline Irlanda & V & & V & \\
\hline Holanda & V & V & V & \\
\hline $\begin{array}{l}\text { Nova } \\
\text { Zelândia }\end{array}$ & V & & & V \\
\hline Noruega & V & & V & \\
\hline \multicolumn{5}{|l|}{ Portugal } \\
\hline Suécia & $\mathrm{V}$ & V & $\mathrm{V}$ & $\mathrm{V}$ \\
\hline $\begin{array}{l}\text { Reino } \\
\text { Unido }\end{array}$ & V & V & & \\
\hline EUA & V & V & V & \\
\hline
\end{tabular}

Fonte: BARZELAY, Michael. Central Audit Institutions and Performance Auditing: A Comparative Analysis of Organizational Strategies in the OECD.

O $3^{\circ}$ INCOSAI (Congress of Supreme Audit Institutions) ocorrido no Brasil trouxe discussões sobre a necessidade do Tribunal de Contas ir além de avaliações financeiras e auditar o desempenho de programas governamentais: 
As discussões e recomendações da $3^{\text {a }}$ INCOSAI foram um incentivo adicional para atualizar as atividades de auditoria no Brasil e desenvolver ainda mais a administração financeira e orçamentária. As ideias discutidas demandaram a criação de novos mecanismos de auditoria capazes de medir não só a conformidade legal da despesa pública, mas também a sua eficiência, eficácia e economia. Como vimos, os resultados do terceiro INCOSAI não se limitaram a esse momento histórico; eles também trouxeram mudanças a longo prazo para a maneira pela qual as tarefas de auditoria são realizados no Brasil. (INTOSAI, 2003, p. 42) ${ }^{31}$

A Auditoria de desempenho ${ }^{32}$ ou Auditoria Operacional - ANOp, como é conhecida no Brasil, também sofreu influência da Generally Accepted Government Auditing Standards (GAGAS) $^{33}$ publicadas em 1972 pelo Government Accountability Office Federal (GAO) $)^{34}$.

Segundo o INTOSAI (2001), "Performance audit" (Anop) é um exame independente da eficiência e eficácia de empreendimento governamentais, programas ou organizações, com o devido respeito à economia e com o objetivo de conduzir as melhorias." Ou seja, fornece informação para melhorar o desempenho e as operações de um determinado programa, objetivando facilitar a tomada de decisão das partes.

Para determinação da eficácia e eficiência os programas ou atividades do governo devem ser avaliados de forma sistemática, aplicando-se os mesmos conceitos de gestão (insumos, processos, produtos, resultados e impactos) utilizados para planejar, monitorar e avaliar.

a. O foco da ANOp é o processo de gestão nos seus múltiplos aspectos: planejamento e organização de procedimentos operacionais e de acompanhamento gerencial, inclusive quanto aos resultados em termos de metas alcançadas. Segue abaixo os aspectos abordados na Auditoria Operacional ${ }^{35}$ :

b. A adequação da estrutura organizacional aos objetivos do órgão ou entidade;

c. A existência de sistemas de controle adequados destinados a monitorar, com base em indicadores de desempenho válidos e confiáveis, aspectos ligados à economicidade e a eficiência;

\footnotetext{
31 INTOSAI: 50 YEARS 1953-2003. A special Publication of the International Organization od Supreme Audit Institutions.

${ }^{32}$ Tradução do termo em inglês Performance Audit.

${ }^{33}$ Normas de Auditoria Governamentais Geralmente Aceitas Referidas como "Yellow Book" ou Livro amarelo, devido a sua capa de cor amarela. Revisado em 2011.

${ }^{34}$ Escritório de Contabilidade do Governo dos Estados Unidos 34 (principal órgão de auditoria estadunidense)

35 BARZELAY, Michael. Central Audit Institutions and Performance Auditing: A Comparative Analysis of Organizational Strategies in the OECD. Governance, Malden, vol. 10, n.3, p. 235-260, jul. 1997.
} 
d. O cumprimento das práticas recomendadas pela legislação para aquisição de bens e serviços;

e. A adequação das aquisições no que se refere aos prazos, a quantidade, ao tipo, a qualidade e aos preços;

f. A guarda e a manutenção dos bens móveis e imóveis;

g. A existência de rotinas e procedimentos de trabalho documentados e atualizados;

h. O uso adequado dos recursos humanos, instalações e equipamentos voltados para a produção e prestação de bens e serviços na proporção, qualidade e prazos requeridos; a extensão do cumprimento das metas estabelecidas pela administração ou legislação pertinente.

Entre os anos de 1980 e 1990 houve um enfraquecimento da habilidade de gestão pública no Brasil resultado de fatores como: redemocratização, o processo de fusão de departamentos e ministérios e do desenvolvimento da terceirização no Executivo. Tais iniciativas culminaram na desacreditação e debilidade da burocracia pública, que sem um corpo de profissionais qualificados e comprometidos com a causa do planejamento, não foram capazes de efetivar investimentos programados.

Nesta mesma época, começou a ser difundido o conceito de Performance Audit por organismos internacionais de desenvolvimento, porém, os primeiros registros de Auditoria Operacional no Brasil datam de 1982, com a criação da Auditoria Programática (antecessora da auditoria operacional) e dos primeiros intercâmbios com outras Entidades de Fiscalização Superior. Em 1985, há o primeiro registro em documento público da atividade em questão, tratase do Manual de Auditoria adotado pelo Tribunal de Contas do Estado da Bahia, inspirado no modelo canadense de Auditoria Integrada.

Este avanço e retrocesso da gestão e planejamento do Estado acompanharam também a ampliação do conceito de desenvolvimento que até a década de 70 era sinônimo de crescimento econômico, porém novos construtos foram incorporados à concepção do termo como: equidade, bem-estar e racionalidade dos processos. Para Carlos Henrique Romão Siqueira:

"A estrutura da sociedade brasileira passou por um profundo processo de diferenciação e diversificação. Nessa trajetória de diferenciação e diversificação, ela colocou para si mesma novos desafios. Esses desafios, como geralmente ocorre em sociedades internamente diferenciadas, raramente são convergentes ou facilmente conciliáveis. É por esse motivo que o planejamento tem hoje um papel estratégico tão relevante. Já não é possível confundir desenvolvimento com crescimento, nem privilegiar uma única de suas dimensões sem riscos de consideráveis desequilíbrios entre classes e grupos 
sociais - desequilíbrios de natureza política ou étnica, de longo prazo e de difícil reparação." (SIQUEIRA, 2011, p. 102)

A "Nova Gestão Pública" mudou a perspectiva de como alcançar resultados por meio da orientação pela lógica de métodos e diversas técnicas que permitiram maior flexibilidade do planejamento público. Esta evolução do modelo gerencial exigiu "um planejamento estratégico das ações desenvolvidas pelo poder público, maior autonomia gerencial, elaboração de indicadores de desempenho e, sobretudo, a avaliação dos resultados obtidos." (SILVA, 2013, p. $6)$.

Entre os anos 1982 e 1987, o TCU publicou atos normativos favorecendo a evolução do conceito da auditoria operacional na instituição. A Portaria $n^{\circ}$ 199/82, aprovou instruções para implantação da auditoria programática. Em 1986, a Portaria n 195/84, aprovou instruções para a auditoria de economia e eficiência. O Tribunal, após a realização de 28 auditorias dessa natureza, reconheceu, em Decisão Plenária (Anexo VI da Ata n 46/1987), a importância da auditoria operacional enquanto atividade de controle, e determinou a adoção de medidas para a sua implantação.

Com a Constituição de 1988, o Tribunal de Contas da União teve a sua jurisdição e competência ampliadas. Além dos poderes para fiscalização contábil, financeira, orçamentária e patrimonial, o artigo 71, inciso IV, atribuiu à competência de realizar auditoria operacional.

A reforma do Estado promoveu a necessidade de avaliar o resultado da ação governamental e não apenas seus aspectos legais. $O$ Tribunal incorporou às suas diretrizes institucionais ações de controle voltadas à melhoria da governança. Após a previsão constitucional, o TCU elaborou o Primeiro Plano de Auditorias Operacionais e em 1989, iniciaram-se as primeiras auditorias operacionais em 35 órgãos da Administração Indireta.

Nos dois anos seguintes, além da conclusão de trabalhos realizados em instituições como: Empresa Brasileira de Agropecuária - EMBRAPA, Banco do Brasil, Companhia Siderúrgica Nacional - CSN, Siderúrgica Aço Minas Gerais - AÇOMINAS, Programa Nacional do Álcool - PRÓALCOL, Instituto de Colonização e Reforma Agrária - INCRA, Superintendência para o Desenvolvimento do Nordeste - SUDENE e na Petróleo Brasileiro S.A. - PETROBRÁS; foi aprovado a resolução que dispunha sobre o exercício da fiscalização Operacional e editada a Portaria n 99/90, que aprovou as Normas Gerais para a Realização de Auditoria Operacional. 
Nesta época, houve uma multiplicação dos órgãos de controle e a exacerbação das funções por eles exercidas. O TCU assumiu papel multifuncional diferente de outros países que adotaram multi-instituições com funções separadas de auditar a gestão, investigar irregularidades e de julgar responsáveis. Esse papel peculiar do Tribunal no Brasil favoreceu discussões e críticas sobre o engessamento das atividades governamentais, Fernando Rezende acredita que:

\begin{abstract}
“...os órgãos de controle sufocaram a administração e instauraram um clima de medo que exerceu um efeito paralisante sobre a operação da máquina pública, emperrando a execução dos investimentos e dos projetos governamentais e afetando inclusive a execução dos projetos contemplados no Programa de Aceleração do Crescimento." (REZENDE, 2009, p. 31).
\end{abstract}

Neste período, o estímulo a prática da auditoria operacional surgiu tanto pela ação de alguns funcionários do Tribunal que já haviam participado de treinamentos no exterior (muitos faziam parte da Secretaria de Auditoria - SAUDI), quanto pela atuação de alguns Ministros da Corte de Contas como: Marcos Vilaça e Fernando Gonçalves. A partir de 1989, a SAUDI passa a divulgar e normatizar a atividade no Tribunal.

Várias ações de construção de uma estrutura de planejamento e controle se iniciaram no primeiro mandato do presidente Fernando Henrique, como a Regulamentação do Plano Plurianual - PPA, a criação da Lei de Responsabilidade Fiscal, a primeira aplicação do PPA e a criação da Controladoria Geral da União - CGU e do SIGPLAN ${ }^{36}$.

A reconstrução das carreiras dos órgãos centrais do ciclo de gestão pública mediante políticas de recuperação de salários e ampliação dos concursos públicos implementados pelo então Ministro, Bresser Pereira, corroboraram para a elaboração de um conjunto de reformas que objetivavam modernizar o Estado, reduzir os desequilíbrios espaciais e sociais e fomentar a produtiva competitiva.

Esse movimento também aconteceu em outros lugares no mundo como o Tribunal de Contas Europeu (ECA - European Court of Auditors) que desenvolveu o "Manual de Auditoria de Desempenho" para auditar práticas de gestão financeira da Comissão Europeia e de programas financiados pelo orçamento da União Europeia - UE. Entre 1993 e 1994, foi firmado um Programa de Cooperação Técnica entre o TCU e o Tribunal de Contas de Portugal, mas não se estendeu.

\footnotetext{
${ }^{36}$ Sistema que auxilia a elaboração e acompanhamento do Plano Plurianual (PPA).
} 
Em 1995, teve início no Brasil a Reforma da Gestão Pública ou Reforma Gerencial do Estado. A reforma abarcou três dimensões:

a) Institucional-legal, voltada à descentralização da estrutura organizacional do aparelho do Estado através da criação de novos formatos organizacionais, como as agências executivas, regulatórias, e as organizações sociais;

b) Gestão, definida pela maior autonomia e a introdução de três novas formas de responsabilização dos gestores - a administração por resultados, a competição administrada por excelência, e o controle social - em substituição parcial dos regulamentos rígidos, da supervisão e da auditoria, que caracterizam a administração burocrática;

c) Cultural, de mudança de mentalidade, visando passar da desconfiança generalizada que caracteriza a administração burocrática para uma confiança maior, ainda que limitada, própria da administração gerencial. (PEREIRA, 1998. Disponível em: <http://www.bresserpereira.org.br/rgp.asp.>).

O discurso da época era a ênfase na fiscalização por resultados e a avaliação de políticas públicas. Para tanto, em 1996, por iniciativa do Presidente do Tribunal, foi realizado o Projeto de Capacitação em Avaliação de Programas de Governo com a Fundação Getúlio Vargas.

A Fundação Getúlio Vargas introduziu as metodologias de avaliação de programa encontradas nos Estados Unidos. A partir deste período, houve uma abertura no Tribunal para o intercâmbio de servidores com EFS dos Estados Unidos, Canadá e Reino Unido. Em decorrência desta ação, em 1998, iniciou-se às tratativas que resultariam no Projeto de Cooperação Técnica com o Reino Unido.

Desde o início dos anos 80, o Governo Britânico veio desenvolvendo políticas voltadas à avaliação do desempenho de sua gestão pública. O Serviço Nacional de Saúde (NHS) foi o precursor desta política que gradualmente se espalhou pelo governo central. A avaliação do serviço público britânico se consolidou entre os anos de 1980 e 2000.

Em 1982, foi determinado que as auditorias operacionais fossem realizadas nos municípios, com exceção de alguns serviços controlados pelos governos regionais, praticamente todas as partes dos serviços públicos do Reino Unido, produzem dados de 
desempenho à disposição do público que começou progressivamente a desempenhar um papel na tomada de decisão central. (TALBOT, 2010, p. 6). ${ }^{37}$

No final de 1980, o governo central, no entanto, começou a sistematizar os processos de avaliação, criando os "Key Performance Indicators" (KPIs). A partir de 1988 foram impostas medidas similares para os "não-departamental Órgãos Públicos" (NDPBs), no início dos anos 1990 fixou-se um conjunto de cerca de 200 medidas de desempenho a serem comunicados anualmente pelas as autoridades locais. Com isso o desenvolvimento da metodologia de avaliação do Reino Unido se tornou cada vez mais voltado para o "resultado".

A Impulsão de políticas voltadas à avaliação de desempenho dos governos do Reino Unido foram suportadas por um ciclo de estabilidade política e econômica derivado do período prolongado de governo de um único partido, The Labour Party. Já o The New Labour Government, liderado por Tony Blair, em 1997, tornou a avaliação de desempenho quase universal em todas as atividades públicas, incluindo a medição do desempenho nos níveis mais altos do próprio governo.

O novo governo trabalhista pretendeu mudar o modo como às decisões de gastos públicos eram tomadas e colocadas em prática. Para isso, eles criaram um sistema mais estratégico quanto à alocação dos recursos e mais focado nos resultados das despesas.

Os parlamentares e acadêmicos ingleses acreditavam que a prática de auditorias públicas precisava ser modernizada para refletir as mudanças significativas no papel do governo ao longo do século XX. Eles queriam ser informados sobre o value for money ${ }^{38}$ das despesas realizadas pelos Departamentos. Essa remodelação da estrutura e configurações de poder fortaleceu, a Inglaterra e a potencializou como ator de influência internacional. Com base sustentada em evidências, seu gerenciamento do ciclo das políticas públicas foi exportado para outros estados que almejavam a racionalização de seus programas governamentais.

Iniciou-se, em 1997, as negociações do Projeto de Cooperação Técnica entre Department for International Development - DFID e o TCU, o projeto CERDS (Controle Externo com foco na Redução da Desigualdade Social). O ano de 1998 pode ser considerado como o milestone

37 Talbot, Colin. PERFORMANCE IN GOVERNMENT: The Evolving System of Performance and Evaluation Measurement, Monitoring, and Management in the United Kingdom. N² 24. November 2010. ECD WORKING PAPER SERIES

38 "Value for Money": refere-se às vantagens socioeconômicas para a sociedade (benefícios tangíveis e intangíveis) obtidas por meio do fornecimento de determinado serviço por parceiro privado, em determinada qualidade, vis-à-vis os custos (tangíveis e intangíveis) para tornar tal serviço disponível através do método tradicional de contratação, ou através da prestação direta pelo Estado. Disponível no Glossário do portal: <www.ppp.mg.gov.br> 
deste acordo: o DFID contratou a KPMG (empresa de auditoria privada) responsável pela consultoria técnica ministrada no TCU. Fruto deste trabalho, o Tribunal elaborou o Manual de Auditoria de Desempenho e após um período de negociações, que havia se iniciado ainda em 1995, foi assinado o Projeto de Cooperação Técnica TCU-Reino Unido, com a duração de três anos (1998-2000).

Em 2000, mesmo ano da publicação dos Objetivos do Milênio - ODM, o acordo firmado anteriormente incorporou metodologias adicionais às técnicas focadas na verificação de programas direcionados a redução da pobreza, promoção da equidade, fortalecimento do controle social e na aproximação com a sociedade civil. Empreendimentos semelhantes foram observados em alguns TCEs ${ }^{39}$, como, por exemplo, Pernambuco e Bahia, que desde 1997, eram credenciados como entidade de auditoria operacional pelo Banco Mundial.

Segundo o Escritório Nacional de Auditoria do Reino Unido ${ }^{40}$ (NAO), é por intermédio da cooperação técnica internacional que se pode promover a governança e prestação de contas na gestão das finanças públicas. A capacidade da auditoria internacional é reforçada mediante capacitação de seus técnicos. O NAO se empenha em compartilhar habilidades, informações e conselhos com outros organismos de auditoria do setor público em todo o mundo. Seu foco em particular são os países assistidos pelo Departamento do Reino Unido para o DesenvolvimentoDFID e os países vizinhos da União Europeia.

O DFID é um departamento governamental, fundado em 1997, que objetiva a promoção do desenvolvimento sustentável e erradicação da pobreza no mundo. Suas principais áreas de trabalho são educação, saúde, serviço social, abastecimento de água e saneamento, governo e sociedade civil (incluindo infraestrutura, setores de produção e desenvolvimento de planejamento). No setor de desenvolvimento de Planejamento, sua principal missão é a divulgação de métodos de avaliação de políticas públicas.

A aplicação da metodologia da ANOp até o ano 2000, era responsabilidade da Secretaria de Métodos Aplicados e Suporte à Auditoria - SEAUDI. Neste mesmo ano, foi criada por meio da Resolução n 140/00, a Secretaria de Fiscalização e Avaliação de Programas de Governo SEPROG, área especializada em auditoria operacional voltada especificamente à avaliação de programas de abrangência nacional e regional. No mesmo exercício, foi aprovado o Manual de Auditoria de Natureza Operacional em substituição ao Manual de Auditoria de Desempenho. $O$

\footnotetext{
${ }^{39}$ Tribunal de Contas Estadual

${ }^{40}$ National Audit Officer. Disponível em: < www.nao.org.uk> Acesso em: 26 out. 2014.
} 
novo manual incorporou técnicas do Projeto de Cooperação Técnica TCU/Reino Unido como: Benchmarking, Indicadores de Desempenho e Mapa de Processos.

Segundo Carlos Alberto Sampaio Freitas, a forma de relacionamento preponderante entre o TCU e outras EFS materializou-se essencialmente na forma de treinamentos, exceto pelo projeto de cooperação técnica com o Reino Unido que transcendeu o intercâmbio teórico e estabeleceu um fluxo de recursos humanos e financeiros:

No que concerne à questão de recursos humanos, além dos 30 participantes do Projeto de Cooperação Técnica inicialmente selecionados, são incorporados mais 20 participantes para integrarem o referido projeto no ano de 1999. Em 2002, ingressaram no projeto em questão mais 30 participantes e, em 2003 , mais 13 participantes foram selecionados. Além das $£ 500.000,00$ aplicadas inicialmente previstas para o Projeto Reino Unido, foram aportados mais $£ 150.000,00$ até o final de 2001. A contrapartida brasileira foi de $£ 622.000,00$, correspondente ao pagamento dos servidores do TCU responsáveis pela administração e execução do Projeto e com os serviços de apoio. (FREITAS, 2005, p. 19).

A reforma gerencial do Estado preconizou mudanças para adoção de um modelo baseado na fixação de objetivos e de mecanismos de avaliação de resultados, desencadeando demandas por informações sobre a implementação das ações do Governo Federal. Verificou-se a adoção de práticas sistematizadas de monitoramento e de avaliação a partir do PPA ${ }^{41} 2000$ 2003.

Este período foi marcado pela institucionalização do Sistema de Monitoramento e Avaliação do Governo Federal (SMA) no PPA 2004-2007, por meio do Decreto no 5.233, de 6 de outubro de 2004. O Ministério do Planejamento Orçamento e Gestão (MPOG), por intermédio da utilização do Sistema de Informações Gerenciais e de Planejamento (SIGPlan), coordenou os processos de monitoramento e de avaliação dos programas do PPA, bem como normatizou e disponibilizou metodologia, orientação e apoio técnico para a sua execução.

A regulamentação do conjunto de ferramentas que hoje se entende como ANOp ocorreu durante os anos de 2001 a 2004:

- 2001 - elaboração e aprovação da técnica de Marco Lógico e técnica RECl;

${ }^{41}$ Plano Plurianual 
- 2002 - elaboração e aprovação: análise stakeholder, análises SWOT, Matriz de Verificação de Risco e Monitoramento das Recomendações de Auditoria de Natureza Operacional;

- 2003 - o Tribunal promoveu encontros de técnicos do Tribunal com consultores legislativos do Congresso Nacional com o objetivo de traçar estratégias para a divulgação das auditorias do TCU nas áreas de interesse do Congresso Nacional;

- 2004 - editada a Portaria n 165/04 que aprova o Roteiro de Elaboração de Relatórios de Auditoria de Natureza operacional.

O modelo de gestão do PPA 2004-2007 se caracterizou pela institucionalização das atividades de monitoramento e de avaliação. Neste período, houve uma junção de vários projetos ministeriais com foco nos investimentos sociais como o ProUni e a Bolsa Família, criado por meio da Lei ํㅜ 10.836, de 9 de janeiro de 2004, e regulamentado pelo Decreto ํo 5.209, de 17 de setembro de 2004.

Segundo, Adriana Santos:

No geral, as mudanças promovidas no período 2004-2007 representaram avanços na medida em que promoveram maior disseminação das práticas de monitoramento e de avaliação entre os órgãos do Governo Federal. Entretanto, os Relatórios Anuais de Avaliação do PPA do período 2004-2007 indicavam a permanência de problemas associados à qualidade dos indicadores; à integração entre a gerência do programa e a coordenação da ação; à falta de qualificação das equipes técnicas para a realização de avaliações; e à falta de interação entre os órgãos executores envolvidos na gestão das restrições (BRASIL, 2004; 2005; 2006), tendo como consequência a dificuldade de obtenção de informações necessárias ao monitoramento e à avaliação. Dessa forma, com base nos aspectos abordados, observa-se que o SMA do PPA ainda não conseguia efetivamente subsidiar e qualificar 0 processo de tomada de decisão. (SANTOS, 2012, p. 43).

Em 2005, o Tribunal se tornou Presidente do Subcomitê de Auditoria de Desempenho na Intosai, objetivando a disseminação das Diretrizes para Auditoria de Desempenho. Estes grupos técnicos se reúnem periodicamente para troca de experiências e avaliação do progresso de suas atividades.

Algumas reuniões, incluindo a 9를 Reunião do Grupo de Trabalho de Auditoria Ambiental em junho de 2004, a 12a Reunião do Grupo de Trabalho sobre a Privatização, em setembro de

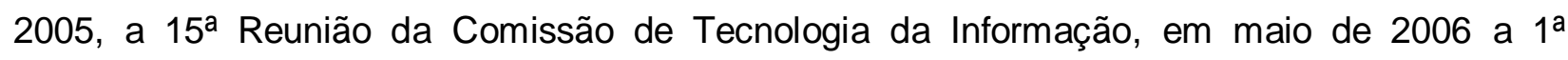


Reunião da Subcomissão de Auditoria de Desempenho, em agosto de 2006 e da 2ª Reunião da Subcomissão de Auditoria de Desempenho e em maio 2008, foram realizadas pelo próprio Tribunal.

Em janeiro de 2007, foi lançado um conjunto de medidas econômicas e de investimentos em infraestrutura, o PAC (Programa de Aceleração do Crescimento), que visava, além de mudanças administrativas e legislativas, a aceleração do crescimento da economia brasileira.

No ano seguinte, foi instituído o sistema de Monitoramento e Avaliação (SMA), Lei no 11.653/2008, que apresentava três agendas prioritárias: PAC, Agenda Social e Plano de Desenvolvimento da Educação (PDE). Neste período, técnicos do TCU identificaram deficiências no modelo de monitoramento e avaliação colocado em prática pelo Executivo, segundo eles: "[...] não dispunham de estrutura organizacional e de pessoas exclusivamente dedicadas ao cumprimento dessas atribuições" (SANTOS, 2011, p. 21).

Em março de 2009, criou-se a Rede de Controle da Gestão Pública, uma ação conjunta de órgãos envolvidos no controle do gasto público no Brasil com intuito de aumentar a eficácia da gestão por intermédio do acompanhamento da aplicação dos recursos públicos nas três esferas de poder: Federal, Estadual e Municipal.

A Rede de Controle que, segundo o TCU (2009) "é um centro decisório interorganizacional que visa aprimorar a efetividade da função de controle do Estado sobre a gestão pública". Pretende, além de formar uma rede de âmbito nacional, desenvolver ações direcionadas à fiscalização da gestão pública, ao diagnóstico e combate à corrupção, ao incentivo e fortalecimento do controle social, ao compartilhamento de informações e documentos, ao intercâmbio de experiências e à capacitação dos seus quadros.

Fazem parte da rede: Advocacia Geral da União (AGU), Associação Brasileira dos Tribunais de Contas dos Municípios (ABRACOM), Associação dos Membros dos Tribunais de Contas do Brasil (ATRICON), Associação Nacional do Ministério Público de Contas (AMPCON), Banco Central do Brasil (BACEN), Câmara dos Deputados, Senado Federal, Conselho Nacional de Justiça, Conselho de Justiça Federal, Controladoria-Geral da União (CGU), Ministério da Fazenda, Ministério do Planejamento, Orçamento e Gestão (MPOG), Ministério da Previdência Social, Ministério Público Federal, Tribunal Superior Eleitoral (TSE) e Tribunal de Contas da União. 
O TCU no levantamento intitulado TC $032.287 / 2010-0$, estudou cerca de 80 processos de avaliação entre os anos de 2004 a 2010, seu objetivo era verificar como foram colocadas em prática as atividades de avaliação e monitoramento no âmbito dos órgãos responsáveis pelos programas finalísticos do Poder Executivo Federal, da Administração Direta. O Tribunal vem desenvolvendo estudos a fim de elaborar um modelo único de sistemas de monitoramento e avaliação, com vistas a assegurar a continuidade de "reestruturação do sistema":

241. Em suma pode-se concluir que os sistemas de monitoramento e avaliação de programas no âmbito da Administração Direta do Poder Executivo Federal, ainda não estão plenamente instituídos, estruturados e implementados. Esta constatação não pode ser generalizada, considerando que em alguns órgãos, como MDS, MEC e MS, em diferentes níveis e formatos, foram organizados os respectivos sistemas, com vistas ao monitoramento e/ou avaliação das ações governamentais, além do modelo único estabelecido pelo MPOG para todos os órgãos públicos.

242. Desta forma e considerando o processo em curso de reestruturação do modelo de planejamento governamental a ser implementado com o novo PPA, é oportuno que este Tribunal desenvolva mecanismos com vistas a acompanhar a evolução da implementação dos instrumentos de monitoramento e avaliação, dada a relevância dos mesmos para o controle do desempenho e dos resultados das ações governamentais, com vistas à adequada governança, melhoria da gestão e promoção da accountability dos gastos públicos. (TCU, 2010).

O início do quadriênio, 2012-2015, marcou-se pelo progresso dos fundamentos dos programas temáticos, introduzindo o conceito de "programa-ação":

"[...] alterações significativas na estrutura adotada pelos últimos três planos plurianuais do Governo Federal. O sentido geral das mudanças é o da busca por um caráter mais estratégico do Plano, criando condições efetivas para a formulação, a gestão e a implementação das políticas públicas" (SERPA, 2011, p. 9).

Em maio de 2012, o TCU aprovou a Resolução n 249/12 que estabeleceu entre os objetivos estratégicos, a iniciativa de contribuir para a transparência da Administração Pública por meio do acesso da sociedade aos serviços prestados pelo TCU.

Em 2013, foi estendida a todas as unidades do Tribunal, a responsabilidade de realizar a Auditoria Operacional. Foram criadas quatro coordenações-gerais: Social, Serviços Essenciais ao Estado, Desenvolvimento Nacional e Infraestrutura subdivididas em secretarias 
especializadas em temas como Educação, Saúde, Desenvolvimento Econômico e Administração do Estado.

Segundo o Ministro João Augusto Ribeiro Nardes ${ }^{42}$, em 2013:

A arquitetura organizacional do TCU foi remodelada mediante a criação de quatro coordenações temáticas associadas às principais áreas de atuação do setor público (social, infraestrutura, desenvolvimento e serviços essenciais ao Estado). Com maior especialização, cada nova secretaria terá melhores condições de identificar as respectivas situações de risco e relevância, bem como de compreender os modelos e os instrumentos de governança que as cercam, contribuindo para seu aprimoramento. Além disso, passaram a ter identidade e foco em sua atuação, concentrando-se, essencialmente, nas áreas sobre as quais poderão ser produzidos relatórios setoriais que servirão de subsídio ao Congresso Nacional na aprovação dos planos plurianuais e dos orçamentos anuais, nos quais são previstos e alocados os recursos necessários para o desenvolvimento nacional. (NARDES, 2013. Disponível em: <http://www.forumnacional.org.br/pub/ep/EP0472.pdf.> Acesso em: 30 out. 2014).

Em Janeiro de 2013, o Tribunal de Contas da União assumiu a presidência da Organização das Entidades Fiscalizadoras da América Latina e Caribe Superiores (OLACEFS), uma organização internacional, autônoma, independente, apolítica e permanente, vinculada ao INTOSAI e que objetiva realizar investigação científica, desenvolver estudo, formação e especialização e prestar assessoria técnica, de assistência e de coordenação para a EFS da América Latina e do Caribe.

Essa capilaridade internacional tem transformado o papel do TCU, antes receptor de cooperação técnica para multiplicador das técnicas empregadas na auditoria operacional e em 2014, foi o responsável por ministrar cursos em Moçambique, Peru, Uruguai, Samoa, Bangladesh e Amsterdã.

Observa-se, portanto, que a ANOp surgiu como um novo conceito de auditoria. Suas características avaliativas compõem um conjunto de ferramentas com aspectos abstratos e concretos criados pela necessidade de adaptação dos governos as novas demandas sociais.

\footnotetext{
${ }^{42}$ Ministro do Tribunal de Contas da União
} 


\section{CAPÍTULO II - AUDITORIA OPERACIONAL: CARACTERÍSTICAS E APLICAÇÕES}

Sem pretensão de exaurir o assunto, este capítulo objetiva conhecer a ANOp a partir da descrição das suas características e aplicações. Como retratado no capítulo anterior, esse conjunto de técnicas que compõem a auditoria operacional se originou da necessidade do Estado em se adaptar a novas demandas sociais tendo como principal característica a flexibilidade.

Os métodos aplicados surgiram, originalmente, da avaliação de projetos, porém novas modelagens decorrentes da incorporação de técnicas empregadas na avaliação de sistemas de Informática e na análise de riscos são possibilidades discutidas internamente pelo Tribunal. Por meio da leitura dos manuais técnicos vigentes no TCU em 2014, descreve-se a ferramenta, seus estágios e sua aplicação.

No estudo ${ }^{43}$ publicado pelo professor Christopher Pollit ${ }^{44}$, concluiu-se com o auxílio da análise de cinco Entidades de Fiscalização no Mundo: França, Finlândia, Países Baixos, Suécia e Reino Unido, que não há um conjunto definido de metodologias que definam a prática da Auditoria de Desempenho, embora ainda sem consenso, esse conjunto de práticas vem sendo padronizado entre os países membros da Intosai. O Brasil adotou esses princípios e normas internacionais na constituição do último Manual de auditoria de desempenho do Tribunal de Contas da União publicado em 2010.

Com duas revisões prévias, a primeira em 1998 e a segunda em 2000, o Manual de Auditoria Operacional do TCU foi novamente revisado e republicado em 2010. Dentre as principais mudanças, ressalta-se a adoção do termo Auditoria Operacional - ANOp que foi empregado pela primeira vez como sinônimo do termo Auditoria de Desempenho.

Auditoria operacional - ANOp é o exame independente e objetivo da economicidade, eficiência, eficácia e efetividade de organizações, programas e atividades governamentais, com a finalidade de promover o aperfeiçoamento da gestão pública. (PORTARIA-SEGECEX № 4, DE 26 DE FEVEREIRO DE 2010).

\footnotetext{
${ }^{43}$ Performance or compliance? Performance audit and public management in five countries. Christopher Pollitt, Xavier Girre, Jeremy Lonsdale, Robert Mul, Hilkka Suma \& Marit Waerness. Oxford University Press, 1999.

${ }^{44}$ Christopher Pollitt é BOF / ZAP Professor de Pesquisa de Gestão Pública do Instituto de Gestão Pública, Katholieke Universiteit Leuven. Anteriormente, ele foi Professor de Gestão Pública no Erasmus Universiteit Rotterdam (1999-2006). Ele também é editor-chefe da Revista Internacional de Ciências Administrativas. Christopher é autor de mais de 60 artigos científicos e autor ou editor de mais de uma dezena de livros acadêmicos.
} 
O Manual foi formulado sobre os pilares das Diretrizes da Intosai empregadas no processo de auditoria de desempenho - Implementation Guidelines for Performance Auditing (ISSAI 3000/1, 2004). De acordo com o Instituto Serzedello Correa ${ }^{45}$ para compreender melhor o instrumento é importante à leitura individual dos três elementos que compõem sua definição.

O primeiro elemento, o exame independente e objetivo, infere que a auditoria deva ser realizada sem representar interesses. A aplicação dos princípios da imparcialidade e objetividade busca a neutralidade e o equilíbrio de conclusões evidenciadas em fatos relevantes e sem exagero de pequenas falhas.

O segundo elemento, influenciado pelas reformas administrativas de estado que migraram do controle de insumos e processos para o controle de resultados e impactos, a ANOp incorporou dimensões de desempenho que a diferenciam da auditoria de conformidade: eficiência, eficácia, efetividade e economicidade. O terceiro elemento, a natureza e objetivo de investigação da Auditoria de conformidade se relacionam a operacionalização das organizações dos programas e das ações de governos com base em critérios definidos em lei.

Figura 1: Diagrama Insumo-Produto.

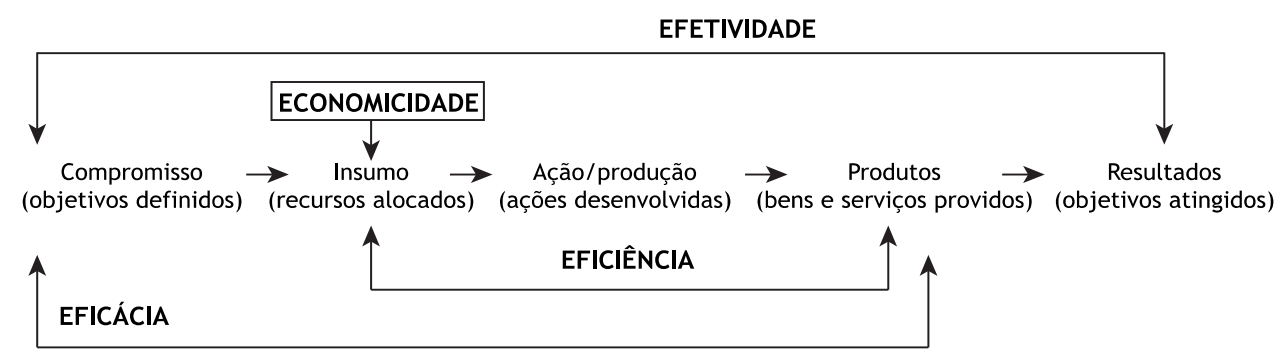

Fonte: Manual Auditoria Operacional TCU 2010. Adaptado de ISSAI 3000/1.4, 2004.

- Economicidade: significa a ausência de desperdício significativo dos recursos investidos. É a minimização dos custos dos recursos utilizados na consecução de uma atividade, sem comprometimento dos padrões de qualidade (ISSAI 3000/1.5, 2004), abrange, por exemplo, a verificação de práticas gerenciais e o benchmarking de processos de compra. Pode incidir superposição do papel com a auditoria de conformidade, caso isso ocorra, a classificação de

\footnotetext{
${ }^{45} \mathrm{O}$ Instituto Serzedello Corrêa (ISC), previsto na Lei Orgânica do TCU (art. 88 da Lei no 8.443/92) e instituído pela Resolução-TCU no 19, de 09/11/1994, é unidade de apoio estratégico do Tribunal de Contas da União (TCU), subordinada à Secretaria-Geral da Presidência (Segepres), que tem por finalidade propor e conduzir políticas e ações de seleção externa de servidores, educação corporativa e gestão do conhecimento organizacional (art. 16 da Resolução-TCU no 214, de 20/08/2008).
} 
uma auditoria específica dependerá do objetivo primordial da auditoria (ISSAI 100/41, 2001). Exemplo: Compra de produtos com qualidade pré-estabelecidos obtidos em licitação tipo Menor Preço.

- Eficiência: está associado ao conceito de economicidade. É a mensuração do esforço dirigido durante o processo de transformação. Verifica a relação entre os produtos obtidos e os recursos empregados mediante exame da minimização do custo, da otimização de insumos e da análise do tempo despendido. Exemplo: Redução de prazos de atendimento ambulatoriais.

- Eficácia: mede a relação dos resultados obtidos e dos objetivos preestabelecidos independentemente dos custos implicados. Para o TCU o conceito de eficácia diz respeito à capacidade de cumprir objetivos imediatos, traduzidos em metas de produção ou de atendimento. Exemplo: $O$ número de crianças vacinadas na campanha nacional de vacinação $x$ meta programada de $95 \%$ de cobertura vacinal.

- Efetividade: é a capacidade de produzir efeito, uma consequência decorrente de uma realidade existente, podendo ser positiva ou negativa. Em termos governamentais, verifica-se a relação entre os resultados da intervenção sobre a população-alvo (impactos observados) e os objetivos pretendidos (impactos esperados). Busca estabelecer a relação de causalidade entre as variáveis do programa e os efeitos observados. Segundo a norma ISSAI 3000/1, examina-se, além do cumprimento de objetivos imediatos (metas de produção ou de atendimento), se os resultados observados foram realmente causados pelas ações desenvolvidas e não por outros fatores.

Verifica-se, também, durante a análise de impacto, o princípio da equidade que trata desigualmente os desiguais, de acordo com RAWLS. "para proporcionar uma autêntica igualdade de oportunidades à sociedade deve atender mais aos nascidos com menos dotes e aos nascidos em setores socialmente menos favorecidos". (apud COHEN, FRANCO, 1993, P. 25). Nesse contexto, a questão da equidade é observada na adoção de ações afirmativas ${ }^{46}$ ou de ações focalizadas no interior de políticas públicas universais. As principais políticas

\footnotetext{
${ }^{46}$ Ações afirmativas também conhecidas como Discriminação positiva são medidas especiais e temporárias, tomadas ou determinadas pelo estado, espontânea ou compulsoriamente, com o objetivo de eliminar desigualdades historicamente acumuladas, garantindo a igualdade de oportunidades e tratamento, bem como de compensar perdas provocadas pela discriminação e marginalização, decorrentes de motivos raciais, étnicos, religiosos, de gênero e outros. Portanto, as ações afirmativas visam combater os efeitos acumulados em virtude das discriminações ocorridas no passado. (“GTI, 1997; Santos, 1999; Santos, 2002)."http://pt.wikipedia.org/wiki/Ação_afirmativa. Exemplo: Cotas Raciais.
} 
auditadas estão relacionadas à renda, gênero, etnia, idade, localidade urbana ou rural e escolaridade, sendo observados:

1. Desigualdade de acesso a recursos do programa. Exemplo: no programa federal TV Escola, identificou-se que a porcentagem das escolas beneficiadas pelo programa no Sudeste (59\%) era quase três vezes maior do que no Norte (21\%).

2. Desigualdade de acesso a bens e serviços do programa. Exemplo: em programa de capacitação de professores da rede pública, por meio de programas televisivos transmitidos via satélite, constatou-se que as escolas localizadas na Região Nordeste tinham menos acesso a equipamentos de TV e vídeo do que as escolas localizadas na Região Sul.

3. Desigualdade na apropriação de benefícios ou de resultados gerados pelo programa. Exemplo: após a implantação de programa destinado a eliminar a hanseníase, observou-se redução mais acentuada na incidência da doença nas regiões Sul e Sudeste do que nas demais regiões do país. (O QUE É ANOp?, p.15).

Completando o raciocínio sobre o conceito da ANOp, o TCU entende que além de subsidiar a tomada de decisão, a Auditoria Operacional aperfeiçoa a gestão pública por meio da manutenção de ferramentas de responsabilização (accountability ${ }^{47}$ ), análise da qualidade dos serviços (geração de valor público) e o estímulo à transparência.

A ANOp se caracteriza por ter maior flexibilidade na escolha dos objetos e dos critérios, nas interpretações e formas de comunicar suas conclusões distintas, no envolvimento dos principais interessados em todas as etapas do trabalho e pela variedade de métodos de investigação e avaliação.

O tema da ANOp pode abranger atividades e sistemas de um órgão, projeto ou programa, utilizando técnicas empregadas na administração, metodologia de pesquisa, estatística, análise econômica e análise de políticas públicas. O gestor e sua equipe participam desde a etapa de

\footnotetext{
47 "Para os autores em língua inglesa, accountability expressa tanto o compromisso pessoal e permanente do administrador de envolvimento ativo na promoção da transparência da gestão, que seria a responsabilidade subjetiva, quanto o dever perante terceiros (os controladores) de prestar contas de seus atos, ou responsabilidade objetiva. Essa última face da responsabilização, perante terceiros, é conhecida na legislação brasileira como prestação de contas (Constituição Federal, 1988, art. 70, parágrafo único e Lei n o 8.443/1992, art. 80). Trata-se de um dever do gestor público perante o órgão controlador (LIMA, 2004). Alguns autores, principalmente escrevendo em espanhol (CLAD, 1999) usam a expressão responsabilização por resultados. O fato é compreensivo quando se observa que o tema está relacionado à gerência por resultados (result oriented management) e à mudança do foco do controle de aspectos procedimentais para resultados. No entanto, a expressão responsabilização por desempenho, afigura-se mais apropriada por incluir, além da dimensão de efetividade, os aspectos de economia, eficácia e eficiência, que são examinados em auditorias de desempenho ou operacionais." (Curso de Auditoria Operacional, Instituto Serzedello Corrêa, TCU. p. 8).
} 
seleção do tema, construção dos critérios até a identificação dos achados e possíveis recomendações.

A ANOp se divide em nove etapas de trabalho que podem ser reagrupadas em cinco etapas principais: seleção do objeto, planejamento, execução, relatório e monitoramento tendo todas as etapas várias subfases de trabalho.

Diversas entidades de Fiscalização Superior no mundo possuem o mesmo ciclo, com exceção da etapa de apreciação do relatório de auditoria exclusivo do TCU. O Tribunal declara que em média, a auditoria dura oito meses. As fases de planejamento, execução e relatório duram cinco meses e a revisão e comentários finais, duram em torno de três meses, podendo variar devido a fatores como: tamanho e/ou experiência da equipe e escopo da auditoria. Geralmente os trabalhos são realizados por dois a cinco auditores.

Figura 2: Ciclo de Auditoria Operacional

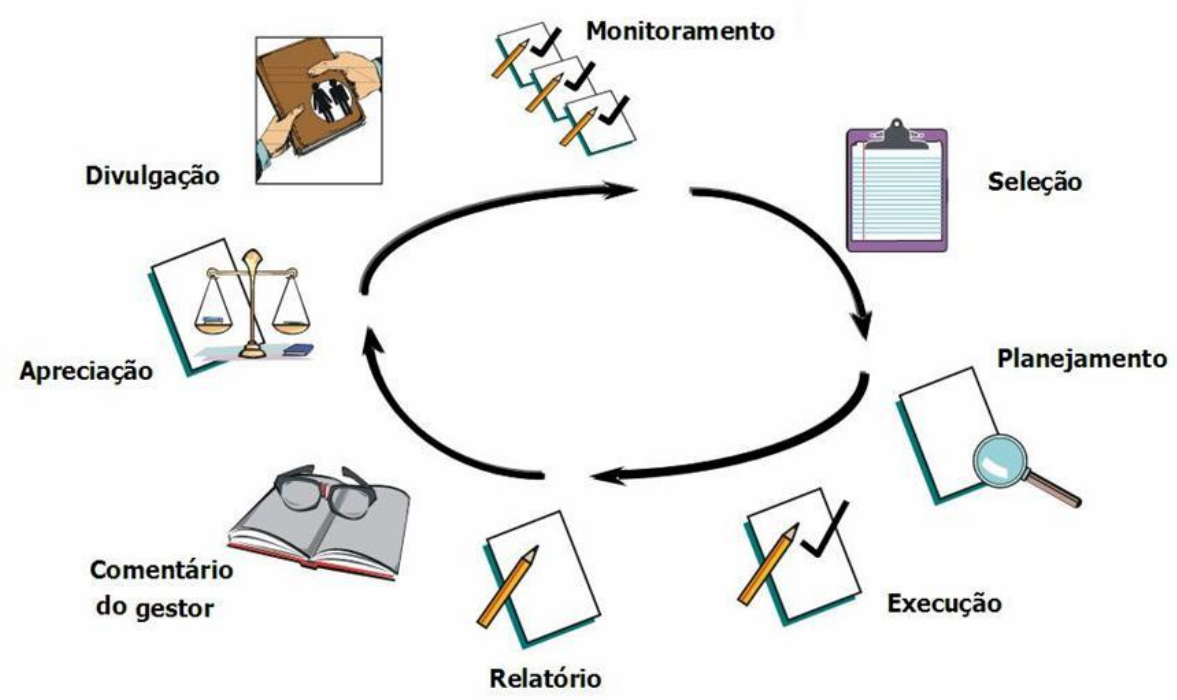

Fonte: Adaptado de NAO, 1996.

\subsection{SELEÇÃO DO OBJETIVO DE AUDITORIA}

É a primeira etapa do processo de Auditoria Operacional, divide-se em: integração do tema com planejamento estratégico, definição de critérios de seleção (agregação de valor, materialidade, relevância, vulnerabilidade) e levantamento. 


\subsubsection{Integração do tema com planejamento estratégico}

O processo de seleção se integra ao planejamento estratégico e ao sistema de planejamento anual (ISSAI 3000/3.2, 2004). Antes do alinhamento com os planos setoriais do governo, a EFS verifica a compatibilidade do estudo com o seu plano estratégico que influenciará investimentos em capacitação, tipos de ferramentas de trabalho a serem desenvolvidas e quantidade de colaboradores alocados por áreas. Fazem parte do plano Estratégico do TCU 2011/2015:

Contribuir para melhoria da gestão e do desempenho da Administração Pública

As demandas ao Estado por melhores serviços, eficiência e efetividade no uso dos recursos públicos têm sido cada vez mais acentuadas. O cidadão exige transparência, honestidade, moralidade e excelência na gestão pública.

Ao Tribunal incumbe importante papel de contribuir para a melhoria da Administração Pública. Para tanto, deve tornar disponíveis para gestores públicos orientações, determinações, recomendações ou avaliações, visando corrigir falhas, evitar desperdícios, melhorar o desenho e a gestão de programas governamentais e políticas públicas, a gestão e o desempenho de órgãos e entidades, a formulação das políticas públicas, aumentar a qualidade de bens e serviços ofertados, ao desempenho dos controles internos, bem como contribuir para o aprimoramento da legislação federal e para a disseminação das melhores práticas observadas na Administração Pública Federal.

Indicadores de Desempenho:

1. Benefícios da atuação do TCU:

a. Benefícios financeiros do controle confirmados;

b. Relação custo x benefício das ações de controle;

c. Contribuição do TCU para melhoria da gestão e do desempenho da Administração Pública.

2. Índice de cumprimento das deliberações do TCU.

3. Índice de governança corporativa dos órgãos da administração federal.

4. Índice de governança corporativa dos órgãos da administração pública

Contribuir para a transparência da Administração Pública

Vivemos um momento sem precedentes, em que se tenta transformar o Estado em instrumento eficiente para o exercício e a realização da cidadania, bem como configurar modelo de Administração Pública Gerencial em substituição ao antigo modelo burocrático e criar a consciência de que o objetivo do Estado deve ser sempre o de proporcionar o bem-estar do cidadão, oferecendo-lhe pleno conhecimento e controle sobre os resultados do estado.

Assim, os cidadãos têm o direito de receber todo tipo de informação ou mesmo buscá-la onde quer que se encontre. Da mesma forma, é dever dos órgãos públicos apresentar à sociedade dados e informações sobre sua gestão. 
Quanto melhor informada for à sociedade, melhor condição terá para exercer o controle social sobre a atuação de seus representantes. (BRASIL, Tribunal de Contas da União. Plano Estratégico do Tribunal de Contas da União 2011/2015. Brasília: TCU, 2011. p. 63).

\subsubsection{Indicadores de Desempenho}

2.1.2.1. Índice de transparência da administração pública:

Em acordo com estes objetivos estratégicos, vários temas de auditorias foram trabalhados ao longo dos últimos anos. Exemplos de Temas de Auditoria Operacional:

- Educação Profissional TC 026.062/2011-9;

- PROUNI E FIES TC 013.493/2008-4;

- Programa Valorização e Formação Continuada de Professores TC 012.485/2005-3;

- Sistemas de Avaliação e Monitoramento da Administração Pública Direta TC 007.590/2013-0;

- Levantamento da função avaliação TC 032.287/2010-0;

- A Minha Casa, Minha Vida TC 033.568/2012-0.

\subsubsection{Definição dos critérios de seleção}

Resolvidas às escolhas estratégicas, segue-se para a definição dos critérios de materialidade, vulnerabilidade, agregação de valor e relevância. As características do objeto devem ser examinadas sobre o prisma dos critérios que variam conforme o contexto. $\mathrm{O}$ principal critério de seleção é a capacidade da auditoria em agregar valor mediante produção de novos conhecimentos e perspectivas sobre o objeto:

1. Discussão sobre nova política pública ou mudança significativa na implementação de programa ou organização de ente governamental;

2. Surgimento de novas ou urgentes atividades ou mudanças de condição;

3. Escassez de auditorias anteriores ou trabalhos de outros órgãos de pesquisa ou de controle sobre o objeto de auditoria; pouco conhecimento sobre a relação causa e efeito entre a ação de governo e a solução de problemas. (MANUAL ANOP, 2010, p. 12).

O critério de materialidade nem sempre pode ser estabelecido por meio de benefícios financeiros, mas pode ser observado no aperfeiçoamento de processos que possam gerar economia e eliminar desperdícios. Já a relevância, correlaciona-se ao interesse da sociedade: 
1. Declarações de prioridades nos planos e orçamentos públicos como o Plano Plurianual, a Lei de Diretrizes Orçamentárias, a mensagem do Executivo que encaminha o orçamento ao Legislativo, os planos setoriais, a manifestação pública de priorização pelo governo;

2. Relatos reiterados de desperdícios, erros, desobediência a procedimentos;

3. Presença na mídia. (MANUAL ANOP, 2010, p. 13).

Segundo a ABNT, as vulnerabilidades são situações ou propriedades intrínsecas do objeto de auditoria que podem estar associadas à ocorrência de eventos adversos. Exemplos:

1. Estruturas gerenciais complexas que envolvem diferentes organizações governamentais de uma mesma esfera ou de esferas de governo diferentes e organizações não governamentais;

2. Falta de informações confiáveis ou atualizadas sobre o desempenho do objeto de auditoria, como alcance de metas, custos dos produtos, público atendido;

3. Problemas de estrutura, de planejamento, de controle;

4. Falta de clareza sobre objetivos, metas, responsabilidades, processos de tomada de decisão;

5. Problemas operacionais com sistemas informatizados. (ISSAI 3000/3.2, 2004.).

\subsubsection{Levantamento}

O levantamento é a fase de transição do planejamento estratégico para o plano operacional mediante coleta de informações sobre a estrutura, funções e operações. O planejamento estratégico, ao qual se liga o processo de seleção, pode ser baseado em análise ou identificação de riscos ou de forma menos teórica, na análise de indicadores de problemas existentes ou potenciais (ISSAI 3000/3.2, 2004). Dependendo do fim e do conhecimento sobre o objeto examinado, o escopo pode ser amplo ou restrito.

O levantamento de escopo amplo tem por objetivo conhecer a organização e o funcionamento das áreas que poderão ser fiscalizadas, bem como identificar objetos e instrumentos de fiscalização (BRASIL, 2002a, art. 238, I e II). É utilizado tanto para fins da Auditoria Operacional quanto para Auditoria de Conformidade, pois verifica possibilidades de fiscalização em âmbitos gerais e específico em curto, médio e longo prazo, sendo uma oportunidade de conhecimento sistêmico das atividades do governo. São exemplos de fontes de informações: 
Planos setoriais, base legal dos programas e organizações, previsão orçamentária e execução financeira, sistemas de informação, estruturas de monitoramento e avaliação, metas, planos de programas e organizações, bem como revisão dos trabalhos de órgãos de pesquisa e de controle sobre os possíveis objetos de auditoria. (MANUAL ANOp, 2010, p. 14).

O levantamento de escopo amplo possui custo mais elevado do que o de escopo restrito, porém como parte dos dados são estáveis podem ser atualizados mediante consulta a bases de dados, mas este levantamento não é realizado com frequência.

Como o levantamento amplo possui um olhar plurianual, muitas vezes pode ser necessária à revalidação dos critérios. O Levantamento do escopo restrito é um estudo de viabilidade dos principais processos operacionais e produtos, sendo a sua conclusão valorativa e substantiva. Examina-se:

1. A qualidade dos indicadores de desempenho já identificados, destacando oportunidades de melhoria;

2. A disponibilidade de dados e sistemas de informações, abordando sua confiabilidade e abrangência;

3. Os relatórios gerenciais existentes e as avaliações anteriormente efetuadas; 4. As limitações à execução da auditoria;

5. A receptividade do gestor em participar da fiscalização;

6. A necessidade de empregar habilidades especializadas na auditoria;

7. Os possíveis prejuízos aos objetivos do controle externo, caso a fiscalização não seja realizada. (MANUAL ANOp, 2010, p. 17).

\subsection{PLANEJAMENTO}

A segunda fase do ciclo de auditoria visa à delimitação do objetivo e escopo da auditoria. As ANOps são gerenciadas como projetos, portanto, nesta fase, define-se as tarefas, a estratégia metodológica, custos, recursos disponíveis e cronograma.

\subsubsection{Atividades de Planejamento}


Figura 3: Fluxograma das atividades do planejamento

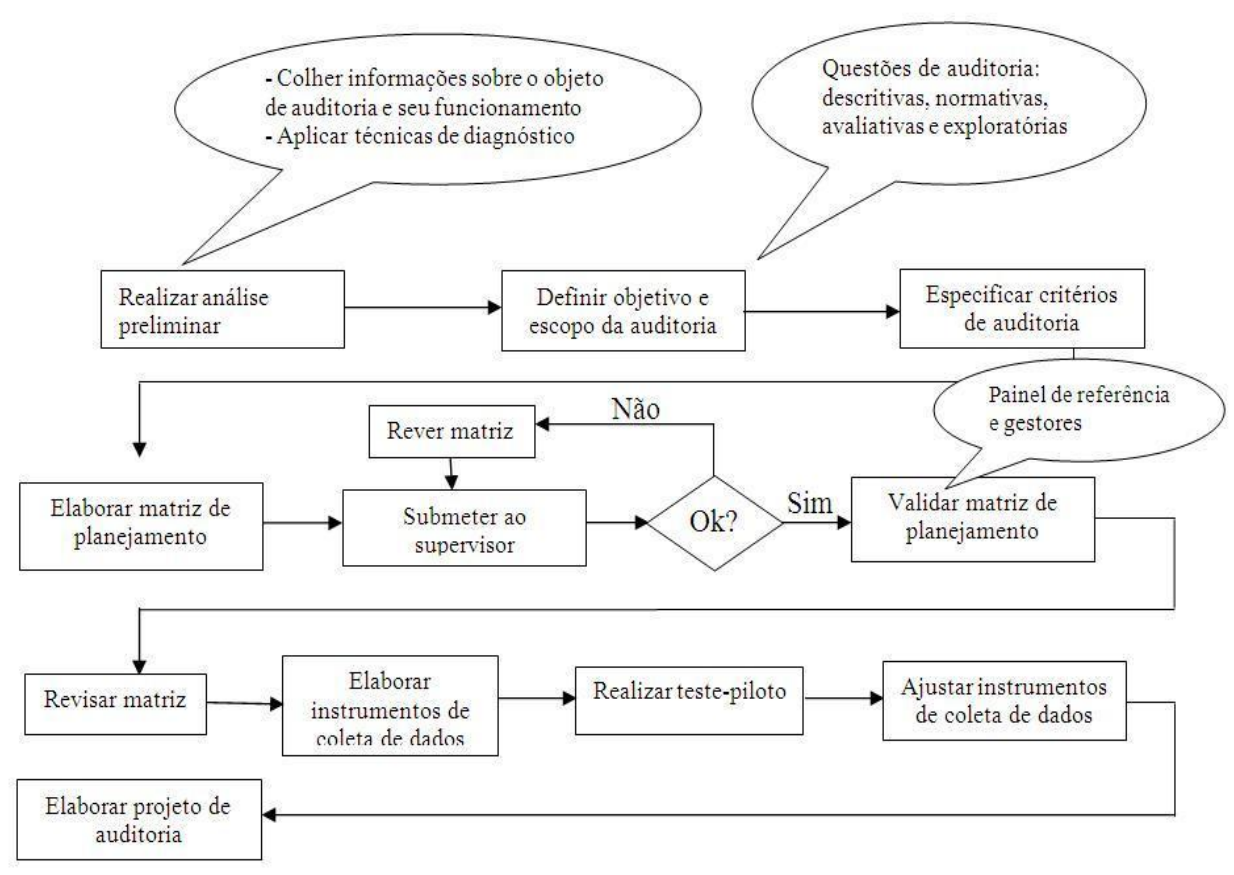

Fonte: Manual ANOp, 2010

\subsubsection{Análise Preliminar}

A análise preliminar consiste no levantamento de informações relevantes sobre o objeto com intuito de adquirir conhecimento necessário para formulação das questões de auditoria. Permite a identificação dos pontos críticos e sua extensão. Algumas das fontes de informações são:

- Legislação orçamentária (PPA, LDO e LOA);

- Documentação Institucional;

- Organogramas, diretrizes internas e manuais operacionais;

- Sistemas de informações da administração pública (SIAFI, SIGPLAN, SIDOR, SIASG);

- Relatórios e estudos produzidos por fontes credenciadas (IPEA, INEP, FGV, UNB, INESC, UNICAMP). (MANUAL ANOp, 2010, p. 55). 
Quadro 4: Informações investigadas na análise preliminar

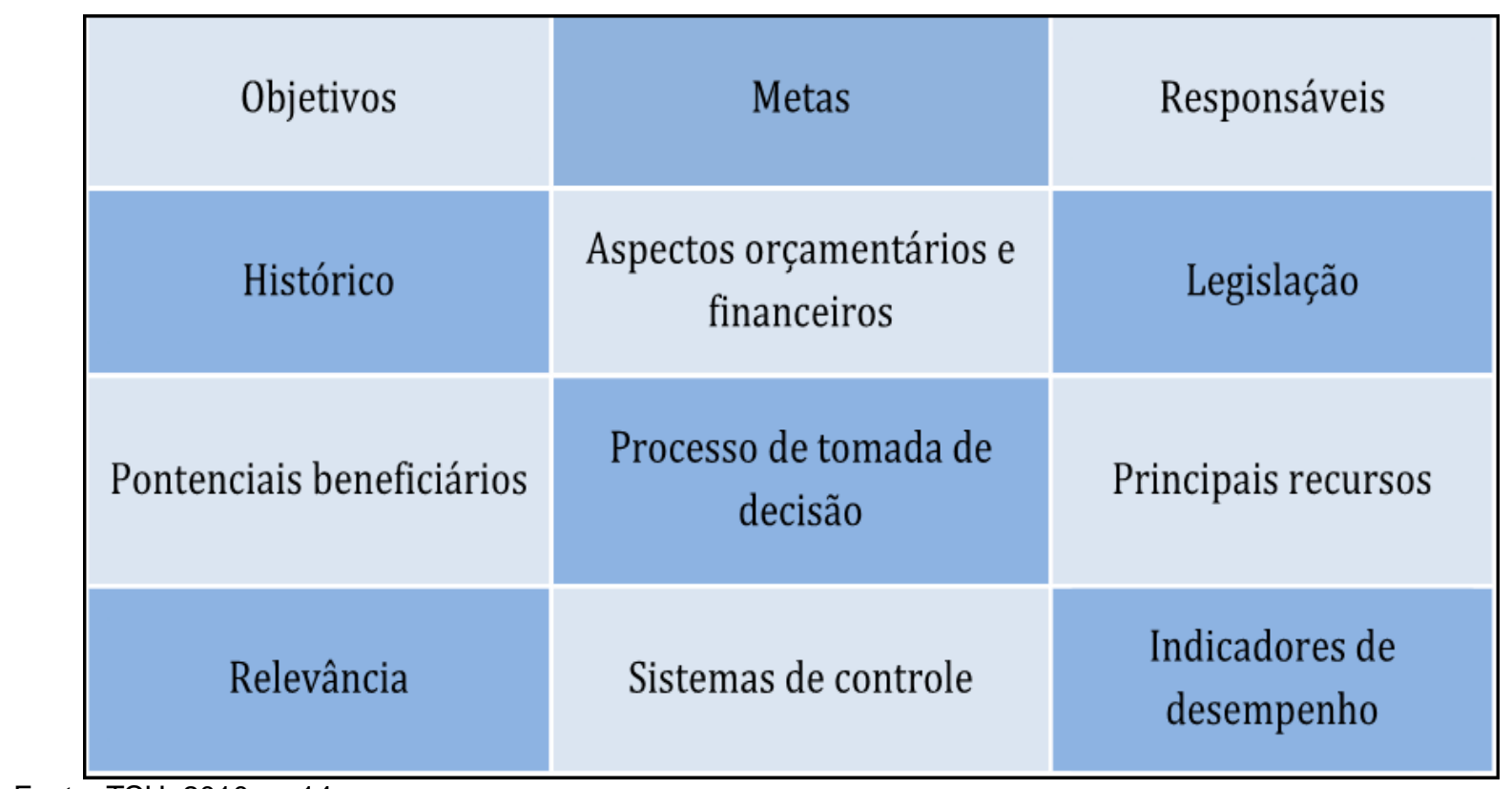

Fonte: TCU, 2010, p. 14

A ISSAI 3000 recomenda que o bom relacionamento com os gestores tenha início no planejamento, pois é neste momento que o primeiro contato é mantido entre a equipe de auditoria e a equipe gestora do programa para apresentação dos objetivos do trabalho e as principais dimensões a serem analisadas. Esse momento deve favorecer a confiança mútua, já que a participação da equipe gestora é fundamental no exercício da ANOp.

A partir deste momento, todos os papéis de trabalhos seguem orientações comuns a Auditoria de Conformidade: registrar, organizar, documentar e referenciar dados e informações. Com base nas duas principais técnicas em auditoria, a entrevista e análise documental, a equipe de auditores deve investigar, primeiramente, os controles internos e sistemas de informação para assegurar o grau de confiabilidade da base informativa.

Para a análise preliminar são levantadas informações sobre o objeto e seu contexto, bem como seu funcionamento (processos gerenciais, fontes de financiamento, grupos de interesse, etc.). A análise preliminar utiliza técnicas de diagnóstico de ambiente (SWOT e análise Stakeholder), de processo (mapa de processo e RECI) e de resultados (mapa de produtos e indicadores de desempenho) prelecionadas pela KPMG. 
Quadro 5: Técnicas mais utilizadas na etapa de planejamento

\begin{tabular}{|c|c|}
\hline Técnica de diagnóstico & Objetivo \\
\hline $\begin{array}{l}\text { SWOT e Diagrama de } \\
\text { Verificação de Risco }\end{array}$ & $\begin{array}{l}\text { Identificar as forças e fraquezas do ambiente interno do objeto da auditoria e as } \\
\text { oportunidades e ameaças do ambiente externo. } \\
\text { Identificar possíveis áreas a investigar. } \\
\text { Identificar fatores de risco e conhecer a capacidade organizacional para o seu } \\
\text { gerenciamento. }\end{array}$ \\
\hline Análise stakeholder & $\begin{array}{ll}\text { 口 } & \text { Identificar principais grupos de interesse (atores interessados). } \\
\text { 口 } & \text { Identificar opiniões e conflitos de interesses e informações relevantes. }\end{array}$ \\
\hline $\begin{array}{l}\text { Mapa de produtos e } \\
\text { Indicadores de desempenho }\end{array}$ & $\begin{array}{ll}\text { 口 } & \text { Conhecer os principais objetivos de uma entidade ou programa. } \\
\square & \text { Representar as relações de dependência entre os produtos. } \\
\square & \text { Identificar os responsáveis pelos produtos críticos. } \\
\square & \text { Desenvolver indicadores de desempenho. }\end{array}$ \\
\hline Mapa de processos & $\begin{array}{l}\text { Conhecer o funcionamento de processos de trabalho. } \\
\text { Identificar boas práticas. } \\
\text { Identificar oportunidades para racionalização e aperfeiçoamento de processos de } \\
\text { trabalho. }\end{array}$ \\
\hline
\end{tabular}

Fonte: Manual ANOP, p. 22.

\subsubsection{Análise SWOT}

A Análise SWOT é um anacronismo formado pelas palavras inglesas: Strenghts (força), Weakness (fraquezas), Opportunities (oportunidades) e Treaths (ameaças). É uma técnica empregada na metodologia de planejamento estratégico organizacional que facilita 0 diagnóstico institucional e cria uma linha de ação.

A base do pensamento da SWOT, de acordo com alguns pensadores, foi desenvolvida, em 1965, pela escola do design do grupo de administração geral da Harvard Business School de Christensen e Bower.

A análise SWOT utilizada na contextualização do objeto pretende eliminar os pontos fracos em áreas em que existem riscos e fortalecer os pontos fortes em áreas em que foram identificadas oportunidades. 
Figura 4: Quadrantes da Análise SWOT.

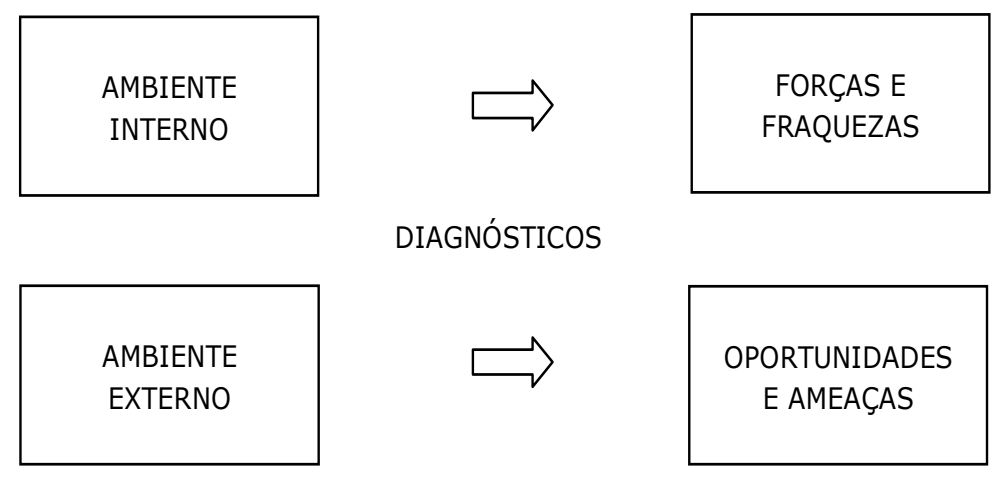

Fonte: Manual Análise SWOT /TCU, 2010, p. 9

As forças são características positivas internas que a organização pode explorar para atingir as suas metas: habilidades, capacidades e competências organizacionais. As fraquezas são características negativas internas que restringe o desempenho organizacional, a ausência de capacidade e/ou habilidade. As oportunidades e ameaças são características externas não controláveis pela organização, que podem potencializar seu crescimento ou impedi-la de atingir suas metas.

Em uma matriz dividida em quatro quadrantes, separam-se do lado esquerdo os itens relacionados ao ambiente interno, forças e fraquezas, e do lado direito, o ambiente externo ficam as oportunidades e ameaças.

Figura 5: Matriz para avaliação do ambiente interno e externo.
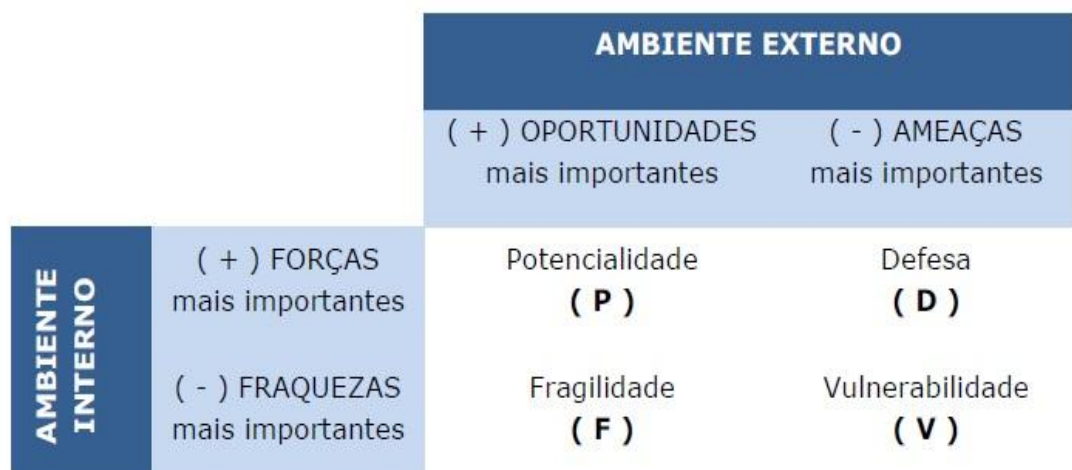

Potencialidade
( P )

Defesa

ragilidade

( F )

Vulnerabilidade

( v )

Fonte: TCU - Análise SWOT e Diagrama de Verificação de Riscos Aplicados em Auditoria, 2010, p. 13. 
Exemplos de forças, fraquezas, oportunidades e ameaças em relatórios do TCU:

- Forças: Estrutura física e humana da gerência do programa adequada as suas atribuições

- Fraquezas: insuficiência de padrões que garantam a qualidade das prestações de contas.

- Oportunidades: Ascensão histórica da oferta de serviços na área da construção civil pode minimizar os custos do programa e fomentar o crescimento do setor no país.

- Ameaças: Suscetibilidade dos gestores locais e desvios de recursos pode reduzir a eficácia do programa. (PORTARIA-SEGECEX № 31, BTCU, 2010, p. 19.).

Para fins de construção da lista que dará origem a matriz da análise SWOT, a equipe de auditoria deve, inicialmente, preparar uma análise preliminar com base em informações externas (mídia, legislação, documentos organizacionais) e em seguida, realizar uma oficina (brainstorming $^{48}$ ) com a equipe de gestão do programa para coleta de dados finais. No momento da análise, observam-se, segundo a Análise de SWOT:

[...] as oportunidades que podem oferecer condições favoráveis, desde que sejam usufruídas. As ameaças devem ser minimizadas com a utilização dos pontos fortes e das oportunidades identificadas, para evitar situações de vulnerabilidade relacionadas ao objeto da auditoria. (ANÁLISE SWOT, 2010 p. 13).

\subsubsection{Diagrama de verificação de risco (DVR)}

O Diagrama de Risco, também conhecido como Matriz de Probabilidade e Impacto de Risco é um método sistemático de identificação, análise, avaliação, tratamento, monitoramento e comunicação de riscos. O TCU entende por risco a possibilidade de ocorrência de eventos futuros que têm potencial para influenciar o alcance dos objetivos de uma organização. Além de identificar os riscos de desempenho, a DVR auxilia também na formulação do "problema de auditoria".

\footnotetext{
${ }^{48} \mathrm{O}$ brainstorming (literalmente: "tempestade cerebral" em inglês) ou tempestade de ideias, mais que uma técnica de dinâmica de grupo, é uma atividade desenvolvida para explorar a potencialidade criativa de um indivíduo ou de um grupo - criatividade em equipe - colocando-a a serviço de objetivos pré-determinados. Disponível em: <http://pt.wikipedia.org/wiki/Brainstorming>
} 
O diagrama dividido em nove quadrantes separa os eventos mais sensíveis (riscos externos e internos) levantados na análise SWOT e mediante a análise das probabilidades de ocorrerem riscos e verificação da existência de controles, prioridades gerenciais e aferição do impacto da ocorrência do risco.

Figura 6: Diagrama da análise de Risco.

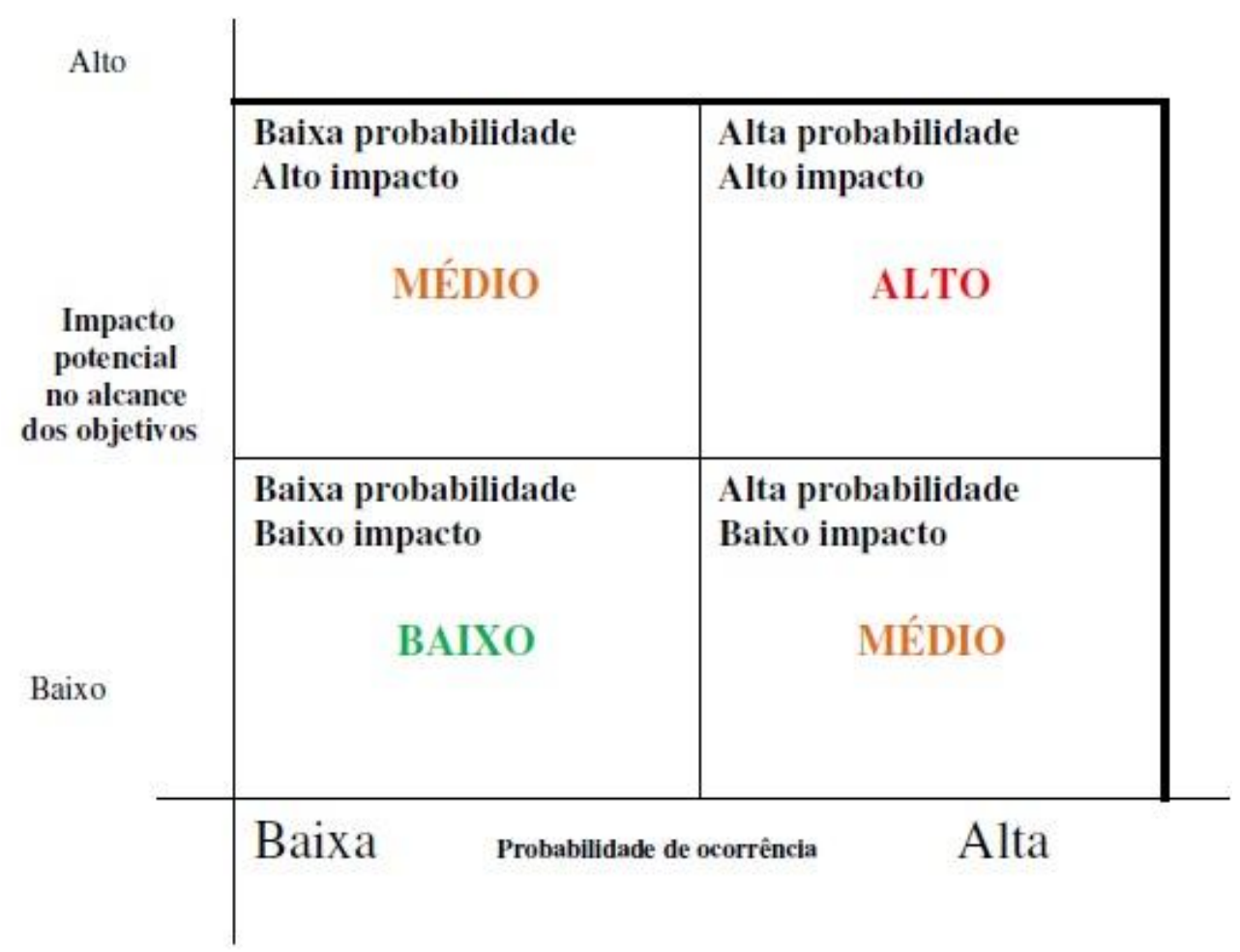

Fonte: Adaptado BTCU, 2010, p. 12

\subsubsection{Análise Stakeholder}

É uma técnica de diagnóstico de ambiente que identifica os principais atores envolvidos, suas expectativas e como esses interesses afetam o desempenho dos programas governamentais: beneficiários, gestores, organizações não governamentais etc, dividindo-se em grupos primários e secundários:

1. Grupos primários são os mais afetados, tanto positiva (os beneficiários) como negativamente;

2. Grupos secundários são os intermediários envolvidos no processo de prestação de serviço. (PORTARIA n 5 TCU, 2002, p. 8). 
Antes de analisar o objeto da auditoria, a equipe de auditores deverá listar a identificação, o papel e o interesse de cada stakeholder, em seguida, deverá identificar os possíveis procedimentos de auditoria nos quais os stakeholder poderão participar.

A coleta de informações e envolvimento dos stakeholders pode ocorrer por meio de encaminhamento de questionários por correio, participação em workshops (oficinas de trabalho), reuniões e participação de membros dos grupos em grupos focais.

\subsubsection{Indicadores de Desempenho}

De acordo com o guia do TCU (2000, p. 9) um Indicador de Desempenho é um número, percentagem ou razão que mede um aspecto do desempenho com o objetivo de comparar esta medida com metas preestabelecidas e está relacionado ao conceito de gerenciamento dirigido por resultados ou results oriented management - ROM.

Os indicadores de desempenho são utilizados como alternativas quando não é possível efetuar mensurações diretas e quantificáveis. Geralmente, composto por variáveis pertencentes aos seguintes grupos: custo, tempo, quantidade e qualidade.

Os indicadores de desempenho, além de observar as dimensões: economicidade, eficiência, efetividade e eficácia, devem possuir as seguintes características:

a. Representatividade - 0 indicador deve ser a expressão dos produtos essenciais de uma atividade ou função; o enfoque deve ser no produto: medir aquilo que é produzido, identificando produtos intermediários e finais, além dos impactos desses produtos (outcomes).

b. Homogeneidade: na construção de indicadores devem ser consideradas apenas variáveis homogêneas.

c. Praticidade: garantia de que o indicador realmente funciona na prática e permite a tomada de decisões gerenciais. Para tanto, deve ser testado, modificado ou excluído quando não atender a essa condição.

d. Validade: o indicador deve refletir o fenômeno a ser monitorado.

e. Independência: 0 indicador deve medir os resultados atribuíveis às ações que se quer monitorar, devendo ser evitados indicadores que possam ser influenciados por fatores externos.

f. Confiabilidade: a fonte de dados utilizada para o cálculo do indicador deve ser confiável, de tal forma que diferentes avaliadores possam chegar aos mesmos resultados. 
g. Seletividade: deve-se estabelecer um número equilibrado de indicadores que enfoquem os aspectos essenciais do que se quer monitorar.

h. Simplicidade: o indicador deve ser de fácil compreensão e não envolver dificuldades de cálculo ou de uso.

i. Cobertura: os indicadores devem representar adequadamente a amplitude e a diversidade de características do fenômeno monitorado, resguardado o princípio da seletividade e da simplicidade.

j. Economicidade: as informações necessárias ao cálculo do indicador devem ser coletadas e atualizadas a um custo razoável, em outras palavras, a manutenção da base de dados não pode ser dispendiosa.

k. Acessibilidade: deve haver facilidade de acesso às informações primárias bem como de registro e manutenção para o cálculo dos indicadores.

I. Estabilidade: a estabilidade conceitual das variáveis componentes e do próprio indicador bem como a estabilidade dos procedimentos para sua elaboração são condições necessárias ao emprego de indicadores para avaliar o desempenho ao longo do tempo. (TCU, Técnica de Auditoria. Indicadores de Desempenho e Mapa de Produtos, 2000, p. 13.).

De acordo com o Ministério do Planejamento, para cada programa finalístico é obrigatório existir ao menos um indicador e para os programas de apoio às políticas públicas e áreas especiais, a presença de indicadores é opcional. (MANUAL ANOp, 2010 apud BRASIL, 2008).

\subsubsection{Mapa de Produtos}

É uma técnica utilizada para obtenção de indicadores de desempenho. Para fins de Auditoria, define-se produto como um bem, serviço ou condição resultante de atividade de uma organização ou indivíduo. Percebe-se, ainda, segundo documento institucional do Tribunal, a resistência da administração pública para gestão orientada por produtos, devido à predominância da gestão de insumos (pessoal, instalações, etc.) e de processos (atividades desempenhadas).

O mapa caracteriza-se por fazer a leitura do produto gerado em cada fase da linha de produção, compondo-se de três itens: insumos, produtos intermediários e produtos finais. 
Figura 7: Exemplo: Mapa de produtos - Comunicação via memorando

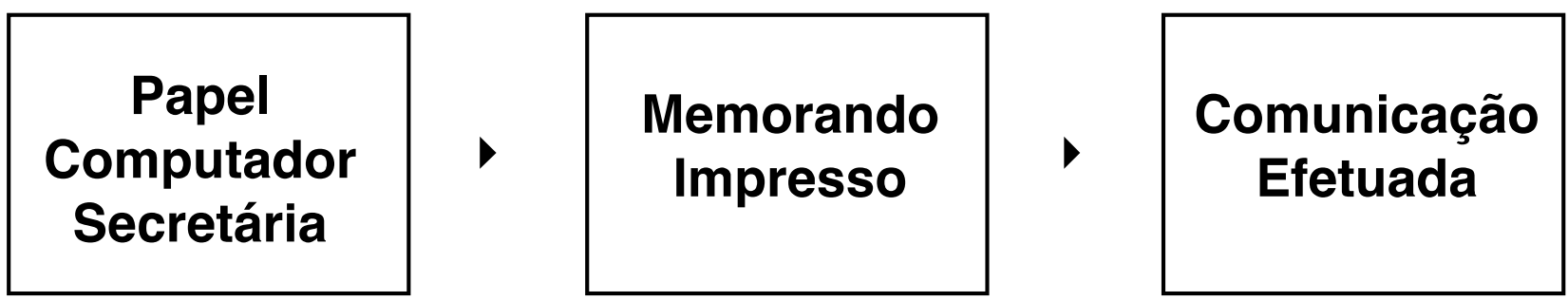

Fonte: Técnicas de Auditoria: Indicadores de Desempenho e Mapa de Produtos, 2000, p. 18.

Na diagramação acima, as caixas à esquerda indicam a existência do insumo ou produto intermediário necessário para que se produza o conteúdo da caixa a direita. Os mapas de produtos não se confundem com mapas de processos, pois os processos nessas representações gráficas são identificados como setas.

\begin{abstract}
O produto final (output) das atividades não deve ser confundido com o impacto (outcome) originado dessas atividades. Enquanto o produto final depende apenas do desempenho das atividades, o impacto que ele causa é afetado por condições externas, que fogem ao controle do órgão ou do indivíduo. (GUIA TCU, 2010, p.19).
\end{abstract}

Os mapas de produtos são elaborados com a participação da equipe auditada por meio da prática de brainstorming em workshop mediado pelos auditores. Logo em seguida, separamse os dez produtos mais relevantes identificando os intermediários e finais. O mapa tem por objetivo mostrar como os produtos se relacionam entre si e com o produto final. Finalmente, são identificados os produtos-chave, que devem atender os seguintes aspectos:

a. Custo: produto cuja obtenção demanda muito mais recursos que os demais;

b. Qualidade: produto de cuja obtenção depende vários outros;

c. Tempo: produto que determina o tempo total gasto na obtenção do produto final. (TCU, Técnica de Auditoria. Indicadores de Desempenho e Mapa de Produtos, 2000, p. 24). 
Identificados os aspectos acima, formulam-se as questões sobre economicidade, eficiência e eficácia que dão origem aos potenciais indicadores de desempenho. Após a definição dos indicadores, averígua-se ainda com os gerentes da instituição se estes se adequam as atividades institucionais, levantando a seguinte questão: "Se os gerentes necessitarem de resposta a esta pergunta, este indicador de desempenho fornecerá a resposta esperada?". (TCU, Técnica de Auditoria. Indicadores de Desempenho e Mapa de Produtos, 2000, p. 30).

Finalmente, fixam-se metas de desempenho: realísticas, exequíveis, desafiadores, comparáveis e claras a serem atingidas pela instituição. Esses indicadores não são imutáveis, seu aperfeiçoamento é fruto de sua utilização, críticas e sugestões de usuários.

\subsubsection{Mapa de Processos}

De acordo com BTCU ${ }^{49}$ Especial, $n^{\circ} 12$, de 30 de junho de 2003, o mapa de processo é a representação de um processo de trabalho por meio de um diagrama contendo a sequência dos passos necessários à consecução de determinada atividade.

Está técnica demonstra visualmente o fluxo de atividades e tarefas interligadas, seus prazos e responsáveis. Se bem elaborado, proporciona a reprodução de processos em organizações distintas, pois permite a comparação do processo realizado e de esperado.

Pode apresentar graus de detalhamento diversos, mas, geralmente, descreve as atividades, pontos de tomada de decisão, movimentos de informação e documentos, pontos de controle, prazos e relações entre etapas do processo.

Similar à elaboração do mapa de produtos, o mapeamento de processos também deve ser elaborado com a participação em oficina dos membros da instituição auditada. Com base em entrevista e documentação disponível, define-se, preliminarmente, o processo que se quer representar.

Utilizando a técnica de brainstorming, identifica-se a tarefa inicial e respeitando uma sequência lógica, verificam-se as atividades resultantes até completar todo o ciclo processual.

\footnotetext{
${ }^{49}$ Boletim do TCU Publicado semanalmente, o periódico destaca selecionadas decisões das Câmaras e do Plenário do Tribunal
} 
Figura 8: Notações utilizadas em mapas de processo.

Retângulo: Indica atividade executada

Utilizar 5 palavras no máximo.

Começar com verbo de ação.

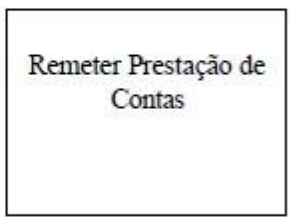

Bandeira: Indica oportunidades de melhoria:

Quantificar sempre que possivel

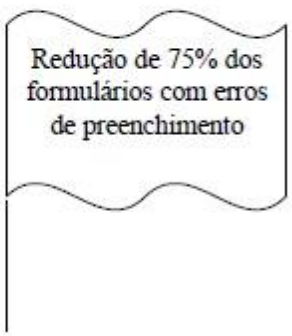

Losango: Indica um ponto de tomada de decisão
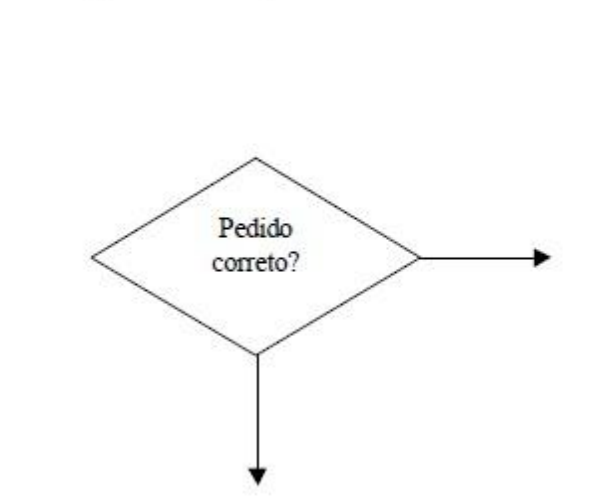

Balão ou nuvem: Atenção, comentários ou explicações:

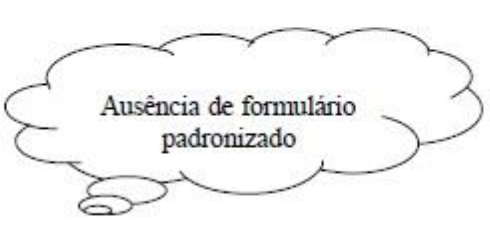

Fonte: BTCU Ed. Especial - Técnica de Auditoria - Mapa de Processos, 2003, p. 6.

A técnica de mapa de processos complementa o mapa de produtos e indicadores de desempenho, pois identifica os processos relativos aos produtos-chave.

\subsection{DEFINIÇÃO DO OBJETO E DO ESCOPO DA AUDITORIA}

Conforme o Manual ANOp (2010, p. 23) a questão de auditoria é o elemento central na determinação do direcionamento dos trabalhos de auditoria, das metodologias e técnicas a adotar e dos resultados que se pretende atingir.

Esta fase assemelha-se a elaboração de trabalhos acadêmicos, pois estabelece o foco da investigação determinando o objetivo da auditoria por meio da formulação do problema e das questões e subquestões a serem averiguadas, buscando-se responder a pergunta: $O$ que motivou a auditoria? 
Quando se define o escopo da auditoria, instituem-se as dimensões e os limites que deverão ser observados durante a execução dos trabalhos, considerando aspectos quanto à clareza, a especificidade, a utilização de termos que possam ser definidos e mensurados e viabilidade investigativa. De acordo com o $\mathrm{GAO}^{50} \mathrm{e} \mathrm{NAO}^{51}$, as questões de auditoria podem ser tipificadas:

a. Questões descritivas: São questões que buscam aprofundar aspectos tratados de forma preliminar durante a etapa de planejamento.

b. Questões normativas: São aquelas que tratam de comparações entre a situação existente e aquela estabelecida em norma, padrão ou meta, tanto de caráter qualitativo quanto quantitativo.

c. Questões avaliativas (ou de impacto, ou de causa e efeito): As questões avaliativas referem-se à efetividade do objeto de auditoria e vão além das questões descritivas e normativas para enfocar o que teria ocorrido caso o programa ou a atividade não tivesse sido executada.

d. Questões exploratórias: Destinadas a explicar eventos específicos, esclarecer os desvios em relação ao desempenho padrão ou as razões de ocorrência de um determinado resultado. (MANUAL ANOp, 2010, p. 22).

As questões devem ser subdividas em partes que não se sobreponham criando uma hierarquia na ordem. A natureza da pergunta influenciará a natureza da resposta e a metodologia a adotar. Pode-se explicitar também, o não escopo da auditoria, tudo aquilo que não será tratado, estabelecendo com precisão os limites do trabalho.

Após a formulação e hierarquização de questões e subquestões, testa-se as questões e eliminam-se as questões não essenciais. Nas questões de difíceis respostas, são ponderadas as dificuldades e recursos disponíveis. Caso, as questões não possuam solução viável ou não tenham potencial de melhoria de desempenho são descartadas.

Definido o problema e as questões, segue-se para próxima fase: especificação dos critérios de auditoria e a elaboração da matriz de planejamento.

\footnotetext{
${ }^{50} \mathrm{GAO}$ - US Government Accountability Office

${ }^{51} \mathrm{NAO}$ - National Audit Office
} 
Quadro 6: Exemplo de formulação de questões e subquestões

\section{Exemplo de formulação de questõese subquestõesde auditoria}

Questão 1: Os controles internos sobre 0 auxilio-doença s̃̃o adequados para garantir, com razoável segurança, o pagamento desses beneficios?

Subquestão 1.1: Os controles internos sobre as atividades de concessão dos beneficios de auxiliodoença são ade quados para garantir, com razoável segurança, o pagamento desses beneficios?

Subquestão 1.2: Os controles internos sobre as atividades de manutenção dos beneficios de auxiliodoença são ade quados para garantir, com razoável segurança, o pagamento desses beneficios?

Questão 2: Qual a cobertura de atendimento do serviço de reabilitação profissional e qual o seu impac to econômico nos gastos com o beneficio?

Subquestão 2.1: A estrutura fisica do serviço e o número de servidores alocados são suficientes para 0 atendimento da demanda por reabilitação profissional?

Subquestão 2.2: Qual a economia que o serviço de reabilitação possibilita e qual o seu potencial de crescimento?

Fonte: Adaptado do relatório de auditoria operacional sobre benefício de auxílio-doença (TC 012.034/2008-7).

\subsection{ESPECIFICAÇÃO DOS CRITÉRIOS DE AUDITORIA E ELABORAÇÃO DA MATRIZ DE PLANEJAMENTO}

Neste momento, são estabelecidos os padrões de desempenho que oferecem parâmetros de comparação entre o ideal e a condição. Essa base que sustenta a compreensão dos achados, conclusões e recomendações da auditoria.

O critério representa a expectativa razoável e fundamentada do que "deveria ser", as melhores práticas e benchmarks contra os quais o desempenho é comparado ou avaliado (ISSAI 3000/Apêndice 2, 2004; GAO, 2007).

Por mais que a auditoria operacional escolha os critérios de forma mais flexível e não limitado, suas fontes ainda seguem orientações preestabelecidas internacionalmente de acordo com a ISSAI 3000 e GAO 2007.

Leis e regulamentos que regem o funcionamento da entidade auditada;

a. Decisões tomadas pelo Poder Legislativo ou Executivo;

b. Referências a comparações históricas e comparações com a melhor prática;

c. Normas e valores profissionais; 
d. Indicadores-chave de desempenho estabelecidos pela entidade auditada ou pela Administração;

e. Opinião de especialista independente;

f. Critérios utilizados em auditorias similares ou empregados por outras entidades de fiscalização superior - EFS;

g. Organizações que realizem atividades semelhantes ou tenham programas similares;

h. Bibliografia especializada. (MANUAL ANOp, 2010, p. 25).

De acordo com a ISSAI 3000, os critérios devem ser razoáveis, exequíveis e relevantes para atingir os objetivos da auditoria, atendendo prioritariamente as características de confiabilidade, objetividade, utilidade, clareza, comparabilidade, completude e aceitabilidade.

Sendo delimitado o problema, questões e critérios, parte-se para a elaboração da Matriz de Planejamento, que consiste em um quadro resumo contendo o problema da auditoria, questões de auditoria, informações requeridas para responder a questão de auditoria, fontes de informação, procedimento de coleta de dados, procedimentos de análise de dados, limitações aos trabalhos de auditoria e o que a análise vai permitir dizer.

A matriz de planejamento é o objeto fundamental de apoio à elaboração do projeto de auditoria e seu processo de validação permite o aconselhamento dos auditores quanto à abordagem a ser adotada, dividindo-se em duas etapas:

a. Painel de referência: debate, com diversos atores, para levantar críticas e sugestões para seu aprimoramento.

b. Apresentação da Matriz de planejamento aos gestores do órgão ou programa auditado. (MANUAL ANOp, 2010, p. 27). 
Quadro 7: Modelo de matriz de planejamento

\begin{tabular}{|c|c|c|c|c|c|c|}
\hline $\begin{array}{c}\text { Questão } \\
\text { /subquestão de } \\
\text { auditoria }\end{array}$ & $\begin{array}{c}\text { Informações } \\
\text { requeridas }\end{array}$ & $\begin{array}{l}\text { Fontes de } \\
\text { informação }\end{array}$ & $\begin{array}{c}\text { Procedimentos } \\
\text { de coleta de } \\
\text { dados }\end{array}$ & $\begin{array}{l}\text { Procedimentos } \\
\text { de análise de } \\
\text { dados }\end{array}$ & Limitações & $\begin{array}{l}0 \text { que a análise vai } \\
\text { permitir dizer }\end{array}$ \\
\hline $\begin{array}{l}\text { Especificar os } \\
\text { termos- chave e o } \\
\text { escopo da } \\
\text { questão: } \\
\text {-critério } \\
\text {-periodo de } \\
\text { abrangência } \\
\text {-atores envolvidos } \\
\text {-abrangência } \\
\text { geográfica }\end{array}$ & $\begin{array}{l}\text { Identificar as } \\
\text { informaçōes } \\
\text { necessárias } \\
\text { para } \\
\text { responder à } \\
\text { questão de } \\
\text { auditoria }\end{array}$ & $\begin{array}{l}\text { Identificar as } \\
\text { fontes de } \\
\text { cada item de } \\
\text { informação }\end{array}$ & $\begin{array}{l}\text { Identificar as } \\
\text { técnicas de coleta } \\
\text { de dados que } \\
\text { serão usadas e } \\
\text { descrever os } \\
\text { respectivos } \\
\text { procedimentos }\end{array}$ & $\begin{array}{l}\text { Identificar as } \\
\text { técnicas a ser } \\
\text { empregadas na } \\
\text { análise de dados } \\
\text { e descrever os } \\
\text { respectivos } \\
\text { procedimentos }\end{array}$ & $\begin{array}{l}\text { Especificar as limitações } \\
\text { quanto: } \\
\text {-à estratégia metodológica } \\
\text { adotada } \\
\text {-ao acesso a pessoas e } \\
\text { informações } \\
\text {-à qualidade das } \\
\text { informações } \\
\text {-às condições operacionais } \\
\text { de realização do trabalho }\end{array}$ & $\begin{array}{l}\text { Esclarecer } \\
\text { precisamente que } \\
\text { conclusões ou } \\
\text { resultados podem } \\
\text { ser alcançados }\end{array}$ \\
\hline
\end{tabular}

Fonte: Extraído de: Problema: expressa, de forma clara e objetiva, aquilo que motivou a auditoria. Manual ANOp, 2010.

Validada a matriz de planejamento, segue-se para elaboração dos procedimentos de coleta de dados, que utiliza instrumentos como entrevistas, questionário, grupo focal e observação direta. Todos os instrumentos obrigatoriamente passam por um teste-piloto, principalmente em auditorias de grande complexidade para conferir o funcionamento do objeto auditado, a qualidade e confiabilidade dos dados.

Finalizando a fase de planejamento, deve ser apresentado um projeto com a síntese do trabalho de auditoria que se pretende realizar. O projeto estruturado em folha de rosto, introdução, objetivo, escopo da auditoria, método e conclusão:

[...] contém a descrição sucinta do objeto de auditoria, objetivos do trabalho, questões a serem investigadas, procedimentos a serem desenvolvidos e resultados esperados com a realização da auditoria. Farão parte do apêndice: a matriz de planejamento, que resume as informações centrais do projeto de auditoria; o cronograma proposto para a condução dos trabalhos; e a estimativa de custos, inclusive de contratação de especialista, quando for o caso. (TCU, p. 31). 


\subsection{EXECUÇÃO}

A terceira fase consiste na obtenção de evidências para respaldar os achados e conclusões da auditoria. Está etapa se divide em quatro subetapas que são trabalho de campo, análise de dados, elaboração e validação da matriz de achados. A execução inicia-se com a identificação dos Achados, que segundo o TCU:

[...] é a discrepância entre a situação existente e o critério. São situações verificadas pelo auditor durante o trabalho de campo que serão usadas para responder às questões de auditoria. $O$ achado contém os seguintes atributos: critério (o que deveria ser), condição (o que é), causa (razão do desvio com relação ao critério) e efeito (consequência da situação encontrada). Quando o critério é comparado com a situação existente, surge o achado de auditoria. (ISSAI 3000/4.3, 2004).

Os achados devem ser avaliados quanto a sua relevância e quanto às causas de desempenho insuficiente. Para o Tribunal, desempenho satisfatório é o esperado e não o perfeito. Mas quando o objeto da auditoria atinge ou excede o critério, isso indica o incidente de boas práticas, porém quando o objeto não alcança o critério, indica oportunidade de aperfeiçoamento do desempenho. A causa é fator responsável pela diferença entre a condição e o critério e o efeito é a consequência (danosa) da persistência dessa diferença. (TCU, Matriz de Achados, 2010, p. 8).

Em alguns processos, como nas auditorias com questões exploratórias, não é possível identificar os quatro atributos do achado, devido à relação de causa não poder ser estabelecida, visto que o critério a ser definido fica a posteriori.

Para fundamentar os achados são necessárias evidências físicas, documental, testemunhal ou analítica. Quando apurado a falta ou fragilidade das evidências, técnicas como a circularização, que consiste na confirmação junto a terceiros de fatos e informações devem ser empregadas.

Quando o objetivo da auditoria inclui a generalização dos achados para o universo pesquisado, as soluções mais comumente adotadas são tratamento estatístico e estudo de caso. Se o estudo de caso é representativo, é possível generalizar os resultados, ou seja, os achados identificados em um caso podem ser aplicados a outros casos (TCU, 2010 apud NAO, 1996, p. 199). 
Quadro 8: Exemplo de Achado de Auditoria

\section{Exemplodeachadodeauditoria}

Achado - Insuficiência de leitos psiquiátricos na maior parte dos estados brasileiros.

Critéio - A quantidade de leitos psiquiátricos estabelecida pela Organização Mundial de Saúde é de 0,43 por mil habitantes.

Candiçäo-O Brasil tem, em média, 0,37 leitos psiquiátricos por mil habitantes.

Causas:

- Distribuição desigual de leitos entre os estados da federação (a região sudeste dispõe de 0,53 leitos por mil habitantes, enquanto na região norte o índice é 0,04)

- Distribuição de leitos não atende a critérios populacionais

- Ausência de planos municipais e estaduais de saúde mental

- Controle social incipiente

\section{Efeitos:}

- Deficiência de atendimento em locais com baixo índice de leitos

- Migração de pessoas com transtornos mentais entre municípios ou entre estados, dificultando o planejamento da atenção à saúde.

Fonte: Manual ANOp, 2010, p. 31

O desenvolvimento do trabalho de campo em si é considerado pelos auditores como a parte menos interessante da auditoria, por ser mecânica e operacional, geralmente é realizada in loco com aplicação de instrumentos desenvolvidos e testados no planejamento.

Durante a execução da auditoria, as situações encontradas são comparadas com os critérios resultando na identificação das causas e efeitos. A causa será a base para as deliberações e se houverem múltiplas causas, devem ser ressaltadas aquelas que modificadas, poderão prevenir situações similares.

É nesse momento que se inicia o preenchimento da matriz de achados, uma ferramenta que, ao contrário das demais descritas no Manual da ANOP, não tem origem externa, mas foi criada e desenvolvida pelo próprio TCU, resultado de sua experiência e incorporado ao arcabouço internacional da ANOp após reconhecimento de sua relevância pela INTOSAI. 
Conforme o entendimento do TCU sobre matriz de achados (2010, p. 35) em que diz: a matriz de achados é um quadro resumo que permite a equipe de auditoria sistematizar as informações relevantes obtidas na fase de execução da auditoria para posterior elaboração do relatório. A matriz é utilizada como base de discussão interna entre a equipe e posteriormente com terceiros, visa a construção lógica dos achados e uma compreensão compartilhada sobre as conclusões.

A matriz de achados se compõe de questões de auditoria, situação encontrada, critérios, evidência e análises, causas, efeitos, boas práticas, recomendações, determinações e benefícios esperados.

\section{Quadro 9: Modelo de matriz de achados}

\begin{tabular}{|c|c|c|c|c|c|c|c|}
\hline \multicolumn{5}{|c|}{ Achado } & \multirow{2}{*}{ Boas priticas } & \multirow{2}{*}{$\begin{array}{l}\text { Recomen- } \\
\text { dacoes e } \\
\text { determi- } \\
\text { nacoses }\end{array}$} & \multirow{2}{*}{$\begin{array}{l}\text { Beneficlos } \\
\text { esperados }\end{array}$} \\
\hline $\begin{array}{l}\text { situaclio } \\
\text { encontrada }\end{array}$ & Critebrio & $\begin{array}{l}\text { Evidelncias } \\
\text { e andilises }\end{array}$ & Causas & Efeitos & & & \\
\hline $\begin{array}{l}\text { Constataş̄e } \\
\text { s de maior } \\
\text { relevaincia, } \\
\text { identificadas } \\
\text { na fase de } \\
\text { excecução. }\end{array}$ & $\begin{array}{l}\text { Padráo } \\
\text { usado para } \\
\text { determinar } \\
\text { se o objeto } \\
\text { auditado } \\
\text { atinge, } \\
\text { excede ou } \\
\text { está aquém } \\
\text { do } \\
\text { desempenho } \\
\text { esperado. }\end{array}$ & 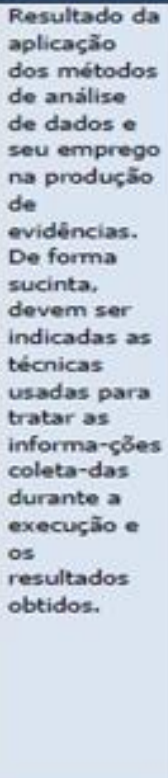 & $\begin{array}{l}\text { Podem ser } \\
\text { relacionadas à } \\
\text { operacionaliza } \\
\text { sảo ou à } \\
\text { concepşão do } \\
\text { objeto da } \\
\text { auditoria, ou } \\
\text { estar fora do } \\
\text { controle ou da } \\
\text { influência do } \\
\text { gestor. } \\
\text { A identificasäo } \\
\text { de causas } \\
\text { requer } \\
\text { evidências e } \\
\text { anslises } \\
\text { robustas. } \\
\text { As } \\
\text { deliberasōes } \\
\text { conterdio as } \\
\text { medidas } \\
\text { consideradas } \\
\text { necessárias } \\
\text { para sanear as } \\
\text { causas do } \\
\text { desempenho } \\
\text { insuficiente. }\end{array}$ & $\begin{array}{l}\text { Consequelncias } \\
\text { relacionadas } \\
\text { às causas e } \\
\text { aos } \\
\text { correspondent } \\
\text { es achados. } \\
\text { Dode ser uma } \\
\text { medida da } \\
\text { releváncia do } \\
\text { achado. }\end{array}$ & $\begin{array}{l}\text { Açöes } \\
\text { identificadas } \\
\text { que } \\
\text { comprovadamen } \\
\text { te levam a bom } \\
\text { desempenho. } \\
\text { Essas açöes } \\
\text { poderäo } \\
\text { subsidiar a } \\
\text { proposta de } \\
\text { recomendaçäes } \\
\text { determinações. }\end{array}$ & $\begin{array}{l}\text { Devem ser } \\
\text { elaboradas } \\
\text { de forma a } \\
\text { tratar a } \\
\text { origem dos } \\
\text { problemas } \\
\text { diagnosticad } \\
\text { os. } \\
\text { Sugere-se } \\
\text { parcimónia } \\
\text { na } \\
\text { quantidade } \\
\text { de } \\
\text { deliberaçöes } \\
\text { e priorização } \\
\text { para solução } \\
\text { dos } \\
\text { principais } \\
\text { problemas. }\end{array}$ & $\begin{array}{l}\text { Melhorias que } \\
\text { se esperam } \\
\text { alcançar com a } \\
\text { implementação } \\
\text { das } \\
\text { recomendaçöes } \\
\text { e } \\
\text { determinasões. } \\
\text { Os beneficios } \\
\text { podem ser } \\
\text { quantitativos e } \\
\text { qualitativos. } \\
\text { Sempre que } \\
\text { possivel, } \\
\text { quantificá-los. }\end{array}$ \\
\hline
\end{tabular}

Fonte: Extraído de: Questão de auditoria: repetir a questão da matriz de planejamento. Manual ANOp, 2010, p. 31

De acordo com o modelo de matriz de achados acima, algumas colunas são absorvidas da matriz de planejamento, salvo quando mudanças substanciais ocorrem durante a fase de execução. Já a coluna de boas práticas serve de sustentação para a coluna de proposta de recomendações e determinações, que trata da origem das deficiências e discrepâncias diagnosticadas. 
Embora estejam configuradas em uma única coluna, as recomendações e determinações possuem caráter diferente. As recomendações possuem um caráter de voluntariedade que, de acordo com Alipio Filho ${ }^{52}$ apud consultoria Zenite ${ }^{53}$ : as recomendações encerram conselhos dirigidos à otimização da gestão, possui caráter menos obrigatório, [...], a Administração poderá se valer de juízo de conveniência e oportunidade na aplicação das condutas recomendadas.

Já as determinações deliberam conteúdo imperativo, seu eventual descumprimento acarreta penalidade ou restrição. Para sua correta aplicação devem ser consideradas o custo de implementação e a economia de recursos decorrente e ainda, que a possibilidade da causa identificada esteja fora do controle do auditado, transcendendo o objeto auditado.

As propostas de melhoria do desempenho administrativo ou operacional são as mais relevantes, sendo que os benefícios esperados se referem às consequências benéficas da implementação das recomendações e devem ser mensuráveis ou prever mecanismos de mensuração. São exemplos de benefícios esperados:

a. custo: estima-se que a implementação dessas recomendações economizaria $\mathrm{R} \$ 2$ milhões de custos operacionais.

b. prazo: o impacto da implementação desta recomendação seria a diminuição do prazo de recolhimento do débito em 30 dias.

c. eficiência: a implementação dessas recomendações permitirá que aproximadamente 250.000 crianças a mais sejam vacinadas com o mesmo volume de recursos.

d. qualidade: espera-se que esta recomendação aumente a qualidade do ensino e leve a um aumento de $5 \%$ nas aprovações em exames. (TCU, Matriz de Achados, 2010 p.14).

\subsection{RELATÓRIO}

Segundo o Manual ANOp apud Brasil (2009, p. 60), o relatório é o principal produto da auditoria, sendo o instrumento formal e técnico que é utilizado para apresentar o objetivo e as questões de auditoria, o método usado, os achados, as conclusões e a proposta de encaminhamento, tendo como requisitos principais a clareza, concisão, conviç̧ão, exatidão, relevância, tempestividade, objetividade, completude e convencimento.

Normalmente, a redação do relatório é compartilhada entre os membros da equipe de auditoria, o que reforça a necessidade de padrões e, estes para a elaboração dos relatórios

\footnotetext{
${ }^{52}$ Alipio Reis Firmo Filho Conselheiro Substituto/TCE-AM.

53 www.adicon.org.br (Ano XVI, n 179, Janeiro de 2009).
} 
segue a norma ISSAI 400/7 da INTOSAI, que estrutura a parte textual em introdução, capítulos principais, análise dos comentários dos gestores, conclusão e proposta de encaminhamento.

O relatório deve ser conduzido como um processo contínuo, levando em conta o ponto de vista do leitor (ISSAI 3000/5.3) e se baseando na matriz de achados, tendo sua estrutura composta por elementos pré-textuais, texto e elementos pós-textuais. O texto deve ser dividido em capítulos, que compreende o relato articulado e argumentado sobre os achados de auditoria, sendo tais argumentos fundamentados na análise das evidências.

Conforme a ISSAI 3000/4.5, 2004, o auditado, assim que possível, deve ter oportunidade de examinar o relatório preliminar de auditoria antes que ele passe a ser de conhecimento público e ainda, o gestor poderá apresentar comentários escritos sobre o relatório preliminar, onde os auditores avaliarão a necessidade de rever pontos ou manter posições discordantes.

Já a conclusão, de acordo com a ISSAI 3000/4.5, 2004, deve trazer as respostas às questões de auditoria, sendo ela a responsável por responder os objetivos da auditoria respaldados na racionalidade e em critérios específicos dela. As conclusões do relatório são afirmações da equipe, deduzidas dos achados. Devem destacar os pontos mais importantes da auditoria e as principais propostas de deliberações (ISSAI 3000/4.3, 2004).

Uma vez finalizado o relatório, o TCU aprecia em Plenário, conforme art. 15 do Regimento Interno e divulga o documento. A ANOp é apreciada e votada por todos os ministros, diferentemente dos outros processos de fiscalização que podem ser apreciados pela primeira ou segunda Câmara.

Após a apreciação, são expedidas cópias do Relatório, do Voto do Ministro-Relator e do Acórdão para os gestores responsáveis, bem como para as autoridades e organizações indicadas no documento. O relatório pode ser considerado uma opinião qualificada sobre o desempenho de um objeto.

Em consonância com a ISSAI 3000/5.4, 2004, p. 41: "Relatórios abrangentes e a distribuição ampla de todos os relatórios são chave para a credibilidade da função de auditoria. Se possível, cada auditoria operacional deve ser publicada em um relatório separado."

O TCU acredita que a produção e divulgação dessas auditorias faz parte do seu papel indutor da responsabilização por desempenho. Logo após a finalização dos relatórios, elaboram-se: 
1. Folder- uma forma de divulgação de baixo custo destinado ao público em geral, impresso em uma única folha, com duas ou mais dobras com as informações mais relevantes;

2. Sumário Executivo - documento com informações resumidas dos trabalhos realizados destinado a órgãos públicos, organismos internacionais, bibliotecas, parlamentares, organizações não governamentais;

3. Notas de imprensa - elaboradas pela assessoria de comunicação.

\subsection{MONITORAMENTO}

É a última fase do ciclo e consiste na verificação dos cumprimentos das deliberações e de seus efeitos. $O$ artigo 243 do Regimento Interno do Tribunal de Contas da União estabelece que monitoramento é o instrumento de fiscalização utilizado pelo Tribunal para verificar o cumprimento de suas deliberações e os resultados trazidos por elas.

Segundo Office of the Auditor General of Canada (performance report, 2001, p. 17):

As EFS dos Estados Unidos, do Reino Unido e da Suécia usam a taxa média de implementação de suas recomendações como medida do impacto de seu trabalho. Para essas instituições, a taxa média de implementação flutua entre 60 e 75\%. (PERFORMANCE REPORT, 2001, p. 17). 
Quadro 10: Classificação do estágio de implementação das deliberações

\begin{tabular}{c|l}
$\begin{array}{c}\text { Implementada / } \\
\text { cumprida }\end{array}$ & $\begin{array}{l}\text { Para ser considerada implementada, deve-se buscar } \\
\text { evidências de que atividades e providências decorrentes da } \\
\text { deliberação foram efetivamente incorporadas ao desenho ou } \\
\text { gestão do objeto auditado. }\end{array}$ \\
$\begin{array}{c}\text { Parcialmente } \\
\text { implementada / } \\
\text { cumprida }\end{array}$ & $\begin{array}{l}\text { Aplica-se essa categoria quando o gestor considerou } \\
\text { concluídas as providências referentes à implementação da } \\
\text { deliberação, sem implementá-la totalmente. }\end{array}$ \\
$\begin{array}{c}\text { Em } \\
\text { implementação }\end{array}$ & $\begin{array}{l}\text { Aplica-se essa categoria se há evidências de que existem ações } \\
\text { em curso no sentido de solucionar as ocorrências apontadas } \\
\text { durante a auditoria e que deram origem à deliberação } \\
\text { proposta. }\end{array}$ \\
$\begin{array}{c}\text { Não } \\
\text { não cumprida }\end{array}$ & $\begin{array}{l}\text { o gestor não adotou medidas com vistas ao atendimento e não } \\
\text { jemonstra a intenção de adotá-las, mesmo sem apresentar }\end{array}$ \\
\hline jũatificativa pertinente.
\end{tabular}

Fonte: TCU, Auditoria Operacional, 2010, p. 49

Cabe ao gestor criar o Plano de Ação, que consiste na formalização das medidas de correção, especificando responsáveis, atividades e prazos de ação a ser apresentado ao TCU. Os membros da equipe de auditoria podem auxiliar o gestor a formular o plano que deve ser incluído em um campo para o registro dos benefícios previstos (benefício quantitativo financeiro, benefício quantitativo não financeiro e benefício qualitativo).

O monitoramento poderá ser realizado por meio de requisição de documentos comprobatórios e consultas a sistemas informatizados ou mediante fiscalização e quando o ele for realizado por meio de fiscalização, seguirá as etapas do ciclo da auditoria operacional. $\mathrm{O}$ monitoramento apresenta uma dinâmica em suas avaliações, pois, por meio dele, também é possível avaliar a qualidade das auditorias.

O Controle de qualidade nas auditorias operacionais é o conjunto de políticas, sistemas, e procedimentos estabelecidos para proporcionar adequada segurança de que os trabalhos alcancem seus objetivos, tenham excelência técnica e satisfaçam as normas e os padrões profissionais estabelecidos (ISSAI 3000/Apêndice 4, 2004). 
Com o intuito de melhorias, assegura-se a qualidade em razão da aderência das atividades de auditoria aos princípios, procedimentos e normas do Tribunal. O controle de qualidade pode ser realizado concomitantemente, pois se integra as atividades desenvolvidas durante o ciclo de auditoria ou a posteriori, exercido por meio de revisões internas e externas dos papéis de trabalho. Os principais instrumentos de controle de qualidade são os checklists, cronograma, matriz de planejamento, matriz de achados, painéis de referência e comentários dos gestores. 


\section{CAPÍTULO III - AUDITORIA OPERACIONAL: UMA AVALIAÇÃO DE SUA IMPLEMENTAÇÃO NO TCU}

Este capítulo aborda o processo de implementação da ANOp no Tribunal a partir da perspectiva do auditor externo, por meio de diálogos que compartilham reflexões e conhecimentos empíricos dos funcionários sobre seu processo de pesquisa, aplicação e legitimação.

O auditor é ator fundamental nesse processo de institucionalização e, portanto, o relato de sua experiência complementa com informações subjetivas a pesquisa documental.

A princípio, a leitura dos pareceres técnicos, manuais internos, notas de imprensa levam a conclusão que, hoje, a Auditoria Operacional faz parte das competências do Tribunal de Contas da União. Contudo, a institucionalização da Auditoria Operacional no Tribunal não seguiu uma trajetória linear e contínua, ao contrário, ela se deu de forma complexa e subjetiva, passando por reiterados momentos de legitimação com idas e vindas não explicitados nos documentos institucionais.

Inicialmente, serão descrito os métodos e procedimentos utilizados na revisão documental, no levantamento bibliográfico e na pesquisa em profundidade realizada com auditores no intuito de revelar as motivações, crenças, atitudes e sentimentos sobre a implementação da ANOp. E em seguida, apresentam-se os resultados deste levantamento.

\subsection{MÉTODOS E PROCEDIMENTOS}

\subsubsection{Pesquisa Documental}

Os primeiros passos no caminho metodológico se deram com a pesquisa documental. Por meio da busca não sistematizada do termo ANOp, no portal do Tribunal de Contas, foram encontrados 474 documentos divididos entre: acórdãos, atas de sessões, manuais, notícias e processos. A segunda fonte de documentos foi a Secretaria de Métodos Aplicados e Suporte à Auditoria (SEAUD) que disponibilizou relatórios e pareceres. 
Paralelamente, foram mantidas buscas em portais nacionais e internacionais, utilizandose os termos: superior audit institution, performance evaluation, auditoria de desempenho e valeu for money.

Priorizou-se a leitura de documentos que retratassem a cooperação técnica entre Brasil e Inglaterra e que de certa maneira, abordassem a evolução do fenômeno de avaliação em entidades de fiscalização superior em geral:

- Reportagem: Auditoria de desempenho governamental e o papel de Entidades Fiscalizadoras Superior (EFS) (Revista do Serviço Público, ano 53, n 2, Abr-Jun 2002);

- Relatório: Projeto CERDS, Resultados alcançados (DFID, 2006);

- Relatório: Planejamento no Brasil: auge, declínio e caminhos para reconstrução (CEPAL/IPEA, 2009);

- Relatório: Performance in Government: The Evolving System of Performance, and Evaluation Measurement, Monitoring, and Management in the United Kigdom (Worldbank, 2010);

- Reportagem: Seminário sobre a Sustentabilidade da Auditoria Operacional (Revista do TCU n 172 Setembro/2010);

- Manual Institucional: Conhecendo o TCU (TCU, 2011)

- Levantamento: Os sistemas de monitoramento, avaliação da administração direta do poder executivo (TCU, 2011);

- Documento Institucional: Plano Estratégico (TCU, 2011);

- Pesquisa: Monitoramento e Avaliação de Programas no Setor Público, A Experiência do PPA do Governo Federal no Período 2000-2011. (Secretaria de Orçamento Federal, 2012);

- Pesquisa: Integração dos Instrumentos de Controle Externo: Uma proposta para a legitimação do modelo brasileiro por meio de isomorfismos institucionais. (ESAF, 2012),

${ }^{54}$ Conhecendo o Tribunal / Tribunal de Contas da União. - 5. ed. Brasília: TCU, Secretaria-Geral da Presidência, 2011. 
- Pronunciamento João Augusto Ribeiro Nardes ${ }^{55}$ : O Controle Externo como Indutor da Governança em prol do Desenvolvimento (TCU, 2013);

- Entrevista João Augusto Ribeiro Nardes: Planejamento e Governança (Revista Transparência Ano 3, Número 10. IBRACON ${ }^{56}, 2013$ );

- Relatório: Discussion paper on the role of an effective Supreme Audit Institution in the reform of service delivery and public sector performance (OCDE);

- Barzelay, Michael. Central Audit Institutions and Performance Auditing: A Comparative Analysis of Organizational Strategies in the OECD;

- Lima, Dagomar. Auditoria de natureza operacional, auditoria de desempenho, auditoria de desempenho operacional e avaliação de programa;

- O controle externo e a nova administração pública: uma visão comparativa. -- Brasília: TCU, 2002. $102 \mathrm{p}$.

\subsubsection{Arcabouço teórico}

A construção da abordagem teórica se deu, principalmente, com a leitura de textos desenvolvidos por James March e Johan Olseen no campo do Neoinstucionalismo e os trabalhos sobre o isomorfismo institucional tratados na obra de Paul Dimaggio e Walter Powell. Secundariamente foi mantida a leitura de textos do livro: Organizações, instituições e poder no Brasil que acrescentam a variável Poder ao eixo teórico sobre isomorfismo institucional.

A abordagem teórica utilizada na pesquisa identifica de forma mais abrangente o isomorfismo institucional, ou seja, a homogeneização de processos e estruturas organizacionais como forma de garantia da sobrevivência de determinada instituição por intermédio da legitimação. (DIMAGGIO \& POWELL, 1992).

De acordo com Meyer, Boli e Thomas (1994) apud Organizações [...] (2003, p. 180), as instituições são regras culturais que, fornecendo significado coletivo e valor a entidades e atividades particulares, integram-nas a sistemas mais amplos. $O$ entendimento da dinâmica ocorrida durante a institucionalização da ANOp, suas relações sociais, valores, atitudes e hábito

\footnotetext{
${ }^{55}$ Presidente do TCU

${ }^{56}$ Instituto dos Auditores Independentes do Brasil - IBRACON
} 
podem aclarar o processo isomórfico vivenciado pelas Entidades de Fiscalização Superior no sentido de apropriação de técnicas e métodos de avaliação de programas públicos.

A institucionalização representa, assim, um processo condicionado pela lógica da conformidade as normas socialmente aceitas. Nessa linha de análise, a legitimidade se torna imperativa para as entidades sociais. Em busca de legitimação social, as organizações tentam conformar suas estruturas e práticas aos valores ambientais. A procura da conformidade se da porque, ao que parece, aumenta as chances de sobrevivência das organizações em grau maior do que a eficácia ou o desempenho imediato das estratégias e dos procedimentos adotados. (MEYER \& ROWAN, 1977).

A conformidade com as características ambientais, ou isomorfismo, decorre da influência de mecanismos coercitivos, miméticos e normativos. (DIMAGGIO \& POWELL, 1983) ${ }^{57}$

\subsubsection{Pesquisa de Campo}

Após a análise documental e levantamento bibliográfico, para complementar as informações e obter maior entendimento do objeto, optou-se pela realização de entrevista semiestruturada por permitir o diálogo mais amplo com os entrevistados, ao mesmo tempo, em que se utilizou questionamentos estruturados de acordo com as variáveis de análise da pesquisa.

A entrevista semiestruturada possibilitou a comparação das informações entre os participantes entrevistados em diferentes períodos e ainda ressaltou suas perspectivas pragmáticas e ideológicas.

Por intermédio da análise do conteúdo, procurou-se a compreensão da mensagem e do sentido no contexto institucional. Enquanto esforço de interpretação, a análise de conteúdo oscila entre os dois polos do rigor da objetividade e da fecundidade subjetividade. (BARDIN, 1977). ${ }^{58}$

\subsubsection{Categorias de Análise das entrevistas}

57 Organizações, instituições e poder no Brasil/Organizadores: Marcelo Milano Falcão Vieira, Cristina Amélia Carvalho. - Rio de Janeiro: Editora FGV.2003.

${ }^{58}$ L'analyse de Contenu. Tradução Luis Anteri Reto e Augusto Pinheiro. 1995. Edições 70. Lisboa. 
As categorias de análise tomaram como base variáveis utilizadas no estudo “Aprendizagem, Isomorfismo e Institucionalização" ${ }^{59}$, publicado em 2005, que estabeleceu o construto Institucionalização por intermédio da combinação de três variáveis:

Liderança e Vínculos propostas por Esman $(1966)^{60}$, Recursos e Estrutura, obtida a partir da junção de duas outras variáveis do mesmo modelo acrescida da variável Legitimidade inserida em função da significância da temática para o processo de institucionalização e observada mediante a utilização da tipologia de Suchman (1995). (FREITAS, 2005, p. 49).

Nesse estudo, levantam-se três grupos de variáveis internas: Liderança, Recursos e Estrutura Interna; e duas externas; Vínculos e Legitimidade.

Quadro 11: Operacionalização do constructo institucionalização

\begin{tabular}{|c|l|l|}
\hline \multirow{4}{*}{ Constructo } & \multicolumn{1}{|c|}{ Variável } & \multicolumn{1}{c|}{ Operacionalização } \\
\hline \multirow{4}{*}{ Institucionalização } & Liderança & $\begin{array}{l}\text { Iniciativas, gestos e decisões favoráveis à } \\
\text { implantação da auditoria operacional. }\end{array}$ \\
\cline { 2 - 3 } & Vinculos & $\begin{array}{l}\text { Convêni os de cooperação técnica, } \\
\text { projetos e programas de treinamento. }\end{array}$ \\
\cline { 2 - 3 } & Recursos/Estrutura Intema & $\begin{array}{l}\text { Recursos humanos, financeiros, } \\
\text { equipamentos, organograma }\end{array}$ \\
\cline { 2 - 3 } & Legitimidade & $\begin{array}{l}\text { Tipos de argumentos encontrados nos } \\
\text { discursos e textos publicados no } \\
\text { Informativo União e na Revista do TCU. }\end{array}$ \\
\hline
\end{tabular}

Fonte: Freitas, 2005.

Com base na categoria de análise acima, foram comparados dois períodos:

- Período 1 - Institucionalização da ANoP entre o período de 1982 até 2004;

- Período 2 - Institucionalização da ANoP entre o período de 2004 até 2014.

Apesar de crucial a influência da variável Liderança no processo de institucionalização da ANOp no Tribunal no período 1, verifica-se que não houveram mudanças relevantes durante o período 2 de 2004-2014, portanto, optou-se por não analisar esta variável por considerar que não haveriam informações relevantes a acrescentar ao estudo.

\footnotetext{
${ }^{59}$ Dissertação apresentada na Comissão Examinadora do FACE /UnB em 2005, com objetivo de identificar o papel dos processos de aprendizagem organizacional na institucionalização da atividade de auditoria operacional no Tribunal de Contas da União em um contexto de isomorfismo institucional.

${ }^{60} \mathrm{O}$ modelo formulado por Milton Esman apresenta um olhar mais micro da construção de normas compartilhadas pelos atores individuais por meio de diferentes variáveis que interagem entre si, se constituindo na base da legitimação das ações. (ESMAN, 1966.)
} 
3.1.4. Seleção da amostra e Instrumento de coleta

- Seleção da amostra

Parte dos entrevistados da presente pesquisa estiveram ativamente envolvidos no processo de institucionalização da ANOp e participaram também, da pesquisa ocorrida em 2005 referente a institucionalização da ANOp no período de 1982 a 2004. Acredita-se que as entrevistas realizadas com indivíduos que estiveram envolvidos durante algum período com a ANOp, possam mostrar a ocorrência de alguma alteração ao longo do tempo.

A princípio, o conjunto de entrevistados seria composto por 10 auditores do Tribunal de Contas da União dividido em dois grupos: com data de admissão no Tribunal antes e depois de 2004. Os entrevistados pertencentes ao grupo anterior a 2004 foram selecionados de acordo com a lista disponibilizada na pesquisa de 2005.

Já os novos auditores foram selecionados aleatoriamente dentre os membros dos relatórios mais recentes de Auditoria Operacional publicados no portal do próprio Tribunal: Assistência Técnica e Extensão Rural-ATER, Enfrentamento a violência domésticas e familiar contra as mulheres e ANOp na Secretaria Nacional de Defesa Civil.

Foram encaminhados correios eletrônicos para todos os possíveis entrevistados, porém apenas nove entrevistas foram consolidadas em sua totalidade (cinco entrevistas com "antigos" e quatro com "novos"). As entrevistas ocorreram durante os meses de Janeiro e Fevereiro/2015: 
Quadro 12: Lista de Entrevistados

\begin{tabular}{|c|c|c|c|c|}
\hline Entrevistados & Ocupação & $\begin{array}{c}\text { Início no TCU } \\
\text { (ano Base 2004) }\end{array}$ & $\begin{array}{c}\text { Data } \\
\text { Entrevista }\end{array}$ & Duração \\
\hline A1 & $\begin{array}{c}\text { Auditor Federal de } \\
\text { Controle Externo }\end{array}$ & Antes & $27 / 01 / 15$ & $0: 23: 48$ \\
\hline A2 & $\begin{array}{c}\text { Auditor Federal de } \\
\text { Controle Externo }\end{array}$ & Antes & $28 / 01 / 15$ & $1: 04: 00$ \\
\hline A3 & $\begin{array}{c}\text { Auditor Federal de } \\
\text { Controle Externo }\end{array}$ & Antes & $29 / 01 / 15$ & $0: 22: 41$ \\
\hline A4 & $\begin{array}{c}\text { Auditor Federal de } \\
\text { Controle Externo }\end{array}$ & Antes & $28 / 01 / 15$ & $0: 22: 58$ \\
\hline A5 & $\begin{array}{c}\text { Auditor Federal de } \\
\text { Controle Externo }\end{array}$ & Antes & $30 / 01 / 15$ & $0: 42: 19$ \\
\hline A6 & $\begin{array}{c}\text { Auditor Federal de } \\
\text { Controle Externo }\end{array}$ & Depois & $03 / 02 / 15$ & $0: 26: 14$ \\
\hline A7 & $\begin{array}{c}\text { Auditor Federal de } \\
\text { Controle Externo }\end{array}$ & Depois & $03 / 02 / 15$ & $0: 49: 19$ \\
\hline A8 & $\begin{array}{c}\text { Auditor Federal de } \\
\text { Controle Externo }\end{array}$ & Depois & $06 / 02 / 15$ & $0: 28: 12$ \\
\hline A9 & $\begin{array}{c}\text { Auditor Federal de } \\
\text { Controle Externo }\end{array}$ & Depois & $06 / 02 / 15$ & $0: 55: 37$ \\
\hline
\end{tabular}

Fonte: Pesquisa de campo realizada no Tribunal de Contas da União em 2015

- Instrumento de Coleta

Para a criação do roteiro de entrevistas foram estabelecidas 20 perguntas, 10 perguntas utilizadas na pesquisa de 2005 e 10 perguntas originais da pesquisa atual, todas agrupadas em três blocos de reflexão que pretendem através da verificação das variáveis: vínculo, recurso legitimidade, constatar o processo de institucionalização da ANOp: 


\section{Quadro 13: Roteiro de Entrevista - Lista de Perguntas}

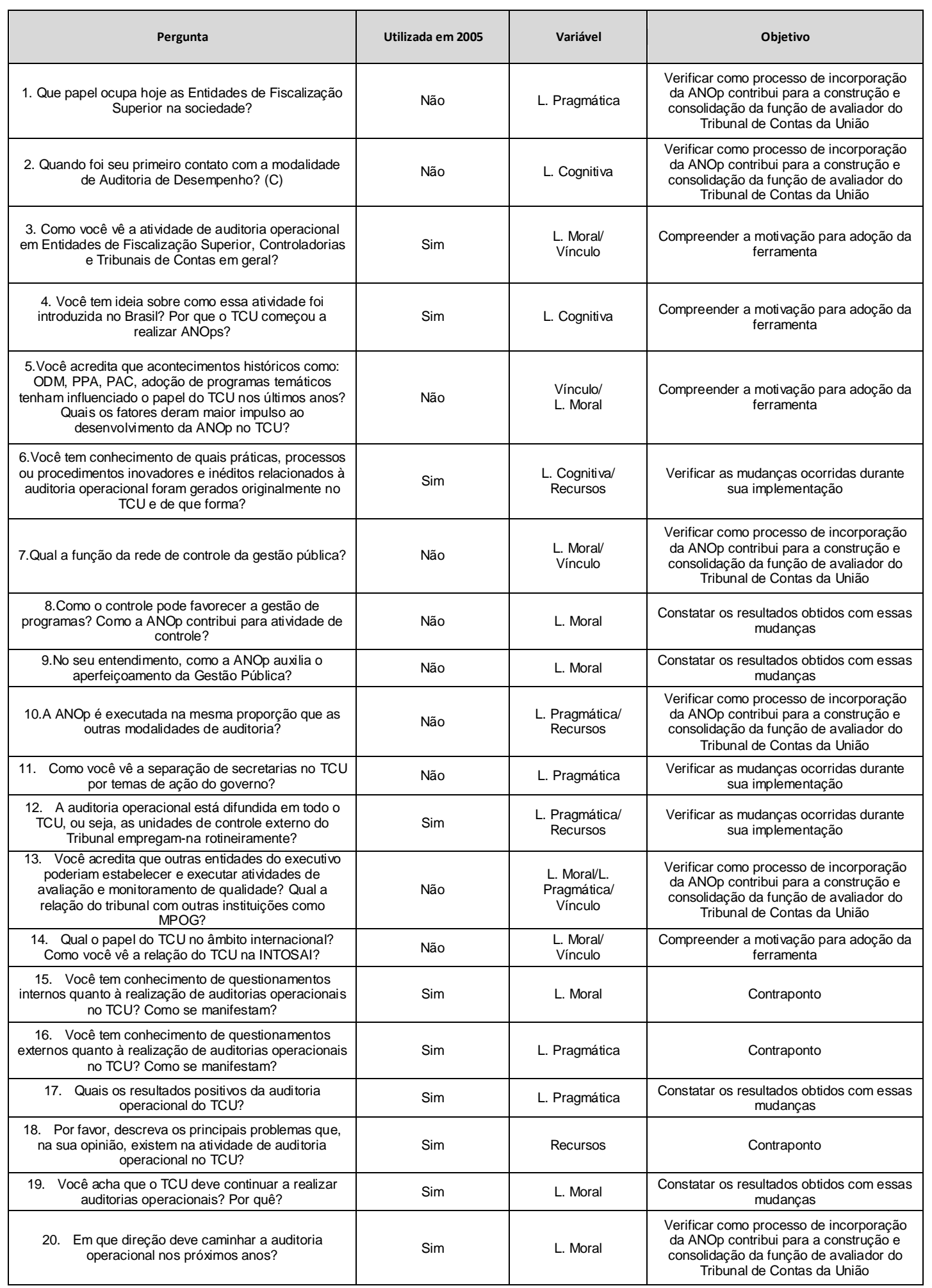

Fonte: Pesquisa de campo realizada no Tribunal de Contas da União em 2015. 
Como já mencionado, os resultados da pesquisa estão estruturados em três categorias de análise: Vínculo, Recurso e Legitimidade. Cada categoria se inicia com uma breve contextualização teórica sobre a variável, seguido pela conclusão apresentada em 2005 e a análise e comparação dos dados atuais de 2014.

\subsection{APRESENTAÇÃO DOS RESULTADOS}

\subsubsection{Vínculos}

Os vínculos são definidos como as interdependências existentes entre a instituição e outros segmentos externos relevantes da sociedade por meio de relações organizacionais, cuja credibilidade proporciona sustentabilidade a organização. (ESMAN apud RODRIGUES ${ }^{61}$ 2006, p. 45).

Na pesquisa realizada em 2005 não apareceram, de forma significativa no conteúdo das entrevistas, o vínculo com outras organizações como universidades, ONGs e o Congresso Nacional sugerindo que era um aspecto ainda não explorado institucionalmente pelo TCU. O incremento dos vínculos validaria a legitimidade cognitiva dos processos isomórficos. A estratégia utilizada nos trabalhos de avaliação de programas conferiu legitimidade pragmática junto aos órgãos governamentais.

...pode-se afirmar que, se por um lado a estratégia do órgão confere legitimidade pragmática a uma parte dos trabalhos e existem fatores isomórficos miméticos e coercitivos que conferem legitimidade cognitiva à atividade, por outro lado persistem questionamentos que impedem que a atividade consiga legitimidade moral em todos os estratos da organização. A resultante desse processo parece ser a continuidade da atividade de auditoria operacional com um dimensionamento de recursos bem inferior às demais atividades de controle de conformidade executadas pelo TCU. (FREITAS, 2005).

A variável Vínculos, conforme já explicitado, refere-se a relação mantida pelo Tribunal com outras instituições, sejam privadas ou públicas, de controle ou acadêmicas com intuito de desenvolver atividades voltadas para prática da auditoria operacional.

Os vínculos significativos e continuados até 2003 foram mantidos por meio de intercâmbios com a INTOSAI e com EFS de diversos países como Estados Unidos, Reino

61 Silva, Marcio Rodrigues. O QUADRO COMPLEMENTAR DE OFICIAIS: UM ESTUDO DE ANÁLISE INSTITUCIONAL EM AMBIENTE MILITAR. UNB/2006 
Unido, Cuba, Noruega, Austrália e Canadá. Esta interação propiciou a introdução no Brasil de metodologias de avaliação de programas advindas tanto do setor privado quanto o público.

Em termos de relacionamento com instituições acadêmicas, registrou-se também o realizado com a Fundação Getúlio Vargas e Universidade Federal do Rio de Janeiro - UFRJ. Nos resultados da pesquisa anterior, constatou-se que embora esses relacionamentos tenham sido relevantes no processo de institucionalização da ANOp, eles se materializaram essencialmente na forma de treinamentos recebidos pelo Brasil:

O Projeto de Cooperação Técnica com o Reino Unido foi uma exceção, já que efetivamente foi estabelecido um relacionamento de cerca de seis anos que transcendeu ao simples intercâmbio de treinamento. $O$ estabelecimento desse vínculo com os órgãos do Governo Britânico parece ter assegurado um fluxo de recursos humanos e financeiros para a atividade de auditoria operacional, que de outra forma não teria se mantido de maneira perene. (FREITAS, 2005, p. 86).

Mediante a análise documental e dos relatos dos auditores em 2015, pode-se observar que na última década houve uma mudança significativa no tipo de relacionamento mantido entre TCU e outras Entidade de Fiscalização no Brasil e no mundo, ocorrendo um amadurecimento no relacionamento e em consequência, uma polarização de grupos e subgrupos de estudos:

Eu participei do grupo técnico que nos últimos dois anos, três anos fez a... a gente chama de harmonização das normas de auditoria. Desde que a gente assumiu a secretaria desse subcomitê a gente tem tido um papel de liderança mesmo. Então o Tribunal passou a ser visto como uma instituição que tem competência técnica, que tem auditores dispostos a colaborar e que tem um acúmulo de conhecimento que pode agregar nesse contexto internacional. sic. (Metodologia do processo de implementação da ANOp no TCU. TCU, 28 jan 15. Entrevista concedida a Helayne Rodrigues da Silva).

O TCU participa hoje ativamente da INTOSAI e esta interação se iniciou em 2004 no momento em que o Brasil foi consultado para elaboração do primeiro documento oficial sobre auditoria operacional emitido pela instituição. $O$ Tribunal seguiu uma tendência verificada em outros campos de cooperação técnica internacional do país, que é de evoluir de receptor para doador. Sua participação não mais se manifestou como um agente receptor de conhecimento, mas como um interlocutor de normas e procedimentos internacionais.

Em busca de um lugar de destaque no cenário global, o Brasil está se firmando como doador de recursos a países pobres. De acordo com 
cruzamento de dados inédito realizado pelo Le Monde Diplomatique Brasil, o governo já fornece mais ajuda internacional do que obtém de países e agências multilaterais, como a ONU. Entre 2005 e 2009, o Brasil recebeu US $\$ 1,48$ bilhão. No mesmo período, doou US $\$ 1,88$ bilhão - uma diferença de US $\$ 400$ milhões em relação ao que recebeu. (ROSSI, Amanda. Artigo: Brasil, um país doador. Revista eletrônica: Le monde diplomatique Brasil. Disponível em: http://www.diplomatique.org.br/artigo.php?id=910 Abril/2011.)

A expansão desta participação ativa fortaleceu também seu poder de influência internacional, fazendo com que o Tribunal participe do Comitê de Normas Profissionais (membro do comitê diretor), Subcomitê de Auditoria de Desempenho (presidente), Subcomitê de Auditoria de Conformidade, Subcomitê de Auditoria de Controle Interno, Grupo de Trabalho sobre Dívida Pública, Grupo de Trabalho sobre Auditoria de Tecnologia da Informação, Grupo de Trabalho sobre Auditoria Ambiental e também, não menos importante, ainda participa na OLACEFS (Organização Latino-americana e do Caribe de EFS) da Comissão Técnica de Auditoria de Meio Ambiente - Comtema, Comissão Técnica de Avaliação de Desempenho das EFS e Indicadores de Desempenho - Cedeir, Comissão Técnica Especial de Ética Pública, Probidade Administrativa e Transparência - Cepat e Comitê de Capacitação Regional -CCR.

De acordo com os teóricos institucionais da tradição sociológica, as organizações sofrem pressões ambientais continuadas no sentido de se tornaram mais homogêneas em termos estruturais e processuais. (MACHADO DA SILVA, 2003). A ênfase na normatização, gradativamente migrou para a implementação das normas.

O isomorfismo mimético consiste na imitação de arranjos estruturais e procedimentos bem-sucedidos implementados por outras organizações, em face da incerteza decorrente de problemas tecnológicos, objetivos conflitantes e exigências ambientais (DIMAGGIO \& POWELL, 1983). Os primeiros anos de pesquisa do TCU fundamentaram-se na reprodução de modelos já praticados em outros países. Nesta última década, verifica-se o fortalecimento do isomorfismo normativo, que se refere à profissionalização envolvendo o compartilhamento de um conjunto de normas e métodos de trabalho pelos membros dos segmentos ocupacionais (DIMAGGIO \& POWELL, 1983).

O foco atual do TCU, segundo os relatos, reside no incremento de capacidades das EFS de países em desenvolvimento.

INTOSAI mudou um pouco o foco, de elaboração de normas pra implementação de normas, implementação no sentido de execução da auditoria com base em padrões profissionais. sic. (Metodologia do processo de 
implementação da ANOp no TCU. TCU, 30 jan 15. Entrevista concedida a Helayne Rodrigues da Silva).

Hoje, o Tribunal mantém acordo de cooperação técnica internacional com o IDI (INTOSAI Development Initiative) apoiando o Programa Marco de Avaliação de Desempenho das EFS $\left(\mathrm{SAl} \mathrm{PMF}^{62}\right.$ ). Seu suporte consiste na disponibilização de um membro de seu quadro de funcionários para executar tarefas relacionadas ao desenvolvimento e atualização de metodologias:

A ML foi formalmente designada pra ocupar $50 \%$ do tempo dela de trabalho pra apoiar um programa chamado $3 i^{63 .}$

Coordenamos com sucesso esse grupo de auditoria operacional, na reforma, na proposta de reforma do subcomitê do PSC, que é o Professional standards Committee, o Comitê de Normas Profissionais. Então o TCU ele meio que tá respondendo a uma demanda internacional por maior participação, e ele tá tendo um protagonismo nos últimos anos bem maior. Como o TCU tem um setor aqui especializado em regulação de indústria e extrativismo de petróleo, etc., aí a gente acaba sendo convidado pra dar apoio porque a comunidade se conhece e ela acaba sabendo quem são os países que estão mais desenvolvidos em determinadas áreas. Então acaba o TCU, de maneira crescente, tendo esse papel. A gente já foi para o Peru pra auxiliar na implementação de auditoria operacional. Agora no ano passado a gente foi pro Chile, porque eles também pediram pra gente ir lá e mostrar nossa experiência como implementar auditoria operacional. Temos cursos de auditoria operacional. Vários cursos online, a distância, cobertura operacional pra países de língua estrangeira... De espanhol... sic. (Metodologia do processo de implementação da ANOp no TCU. TCU, 30 jan 15. Entrevista concedida a Helayne Rodrigues da Silva).

Existindo também uma preocupação do envolvimento do país em questões relacionadas a América do Sul, o Tribunal tem promovido reflexões em áreas ambientais e extrativistas:

Mas nos últimos anos também a gente tem tentado adotar um papel de protagonista na América do Sul, na América Latina. Então o TCU hoje é presidente da OLACEFS...Então a gente tá oferecendo curso, a gente tá participando de... Esses países a maioria é controladoria. Poucos são tribunais. A gente chama pra participar de trabalhos coordenados com o TCU também. Pra ao mesmo tempo de tentar dar uma resposta mais regional, por exemplo, na questão amazônica, então tá... Tá sendo feito um trabalho agora. A gente fez um trabalho primeiro pra Amazônia brasileira, chamando os tribunais de Contas dos Estados pra ver como que é a gestão ambiental em cada um dos nove Estados ali que... Que englobam a Amazônia legal. E agora tá sendo feito um trabalho com as entidades de outros países né? Que tem a Amazônia

\footnotetext{
62 Supreme Audit Institutions Performance Measurement Framework

${ }^{63} \mathrm{O}$ programa 3i (ISSAI Implementation Initiative) é um programa de implementação de novas EFS e o Tribunal participa da elaboração de material de treinamento.
} 
também tem o bioma Amazônia. sic. (Metodologia do processo de implementação da ANOp no TCU. TCU, 4 fev15. Entrevista concedida a Helayne Rodrigues da Silva).

Como mencionado acima, mantém-se ainda convênios com Tribunais de Contas Estaduais - TCE(s) cuja execução garante a extensão da auditoria operacional em esferas locais:

Eu fiz um trabalho há dois anos com nove... com apoio de nove Tribunais de Contas dos Estados, e nove secretarias do TCU, na Região Norte. Dos TCEs todos que vieram tinham formação. sic. (Metodologia do processo de implementação da ANOp no TCU. TCU, 4 fev 15. Entrevista concedida a Helayne Rodrigues da Silva).

Foi feito pro exemplo, a análise de controles internos em municípios do Estado de Roraima que foi feito pelo TCU, o tribunal de contas do Estado e a CGU. Uma equipe mista. Nós fazemos auditorias coordenadas com os Estados há muitos anos no âmbito do Promoex ${ }^{64}$ (Programa de Modernização do Controle Externo dos Estados e Municípios Brasileiros )que já acabou, mas depois que o Promoex acabou a gente acabou fazendo essas auditorias coordenadas, que eram auditorias operacionais em programa de governo, mas a gente não invocava a rede de controle. A gente fazia dentro deste guardachuva do Promoex. sic. (Metodologia do processo de implementação da ANOp no TCU. TCU, 30 jan 15. Entrevista concedida a Helayne Rodrigues da Silva).

Ainda dentro do âmbito internacional, o TCU também participa do Audit Committe e Forum $(A C F)^{65}$, um fórum internacional de auditoria fundado pela empresa de auditoria KPMG em 2002, que tem como objetivo realizar pesquisas técnicas e discussões sobre normas de auditorias no mundo.

Desse modo, constata-se o desenvolvimento de vínculos internacionais e nacionais com outras entidades de fiscalização no TCU, contudo quando questionados quanto às atividades de avaliação e monitoramento mantidas pelo Executivo, verifica-se que não há vínculo real ou interlocução direta com os Ministérios.

O Tribunal poderia atuar como um facilitador, como um incentivador da boa gestão na Administração Pública Federal. Só que essa interlocução por ministério, ela, na minha opinião, ela é muito fraca. sic. (Metodologia do

\footnotetext{
64 O Programa de Modernização do Sistema de Controle Externo dos Estados, Distrito Federal e Municípios Brasileiros - PROMOEX -, têm por objetivo geral fortalecer o sistema de controle externo como instrumento de cidadania, incluindo o aperfeiçoamento das relações intergovernamentais e interinstitucionais, com vistas, inclusive, ao controle do cumprimento da Lei de Responsabilidade Fiscal (LC 101/2000). http://www.controlepublico.org.br/index.php/institucional/promoex

65 http://www.acf.co.za/about/
} 
processo de implementação da ANOp no TCU. TCU, 6 fev 15. Entrevista concedida a Helayne Rodrigues da Silva).

Embora o discurso institucional se preocupe com o sistema de monitoramento e avaliação do Poder Executivo, o Tribunal não atua como um facilitador nesses órgãos:

O PPA e o monitoramento dele não é um instrumento que consiga dar uma resposta pra sociedade a respeito de desempenho né? Então a sistemática de monitoramento do PPA ela é muito uma auto avaliação de cada Ministério. E aí quando você coloca o gestor pra se auto avaliar, não tem esse caráter externo de avaliação e, assim eu não vejo muito o que o Ministério do Planejamento faz com isso. E com relação aos Ministérios terem setores de avaliação de desempenho eu acho muito positivo. Hoje o que a gente conhece de mais, digamos sofisticado de avaliação de desempenho do próprio Ministério é a SAGI ${ }^{66}$ do Ministério de Desenvolvimento Social. Eles não fazem as avaliações, mas eles contratam. Então tem um corpo de servidores competentes pra fazer a contratação de avaliações e aí geralmente eles contratam universidades pra fazer avaliação. E são avaliações muito boas. Então a SAGI tem dinheiro pra contratar e aí enquanto o TCU ia lá com quatro auditores a SAGI tinha contratado uma avaliação em que a Universidade Federal de Pernambuco disponibilizou cinco doutores pra essa avaliação com 200 pesquisadores de campo, com recurso pra coletar informação. E aí a gente viu o seguinte: aqui não precisa da gente atuar. Primeiro porque já tem atuação do próprio órgão. Que bom seria se as unidades dos Ministérios, se cada Ministério tivesse uma unidade lá pra avaliar e o TCU pudesse só fazer metaavaliações. sic. (Metodologia do processo de implementação da ANOp no TCU. TCU, 28 jan 4 fev 15. Entrevista concedida a Helayne Rodrigues da Silva).

Se eles tivessem um trabalho mais... Fizessem estudos mais profundos... Se não fossem muito básicas, talvez a gente... E o nosso trabalho ficasse bem mais é... A gente podia fazer uma meta-avaliação, por exemplo, que seria uma coisa muito interessante. Tem algumas controladorias que são assim. $O$ Canadá, por exemplo, ele faz uma meta-avaliação. sic. (Metodologia do processo de implementação da ANOp no TCU. TCU, 6 fev 15. Entrevista concedida a Helayne Rodrigues da Silva).

Então o Inep faz avaliação. O MPOG tem uma secretaria de avaliação, de monitoramento e avaliação. Então os ministérios fazem avaliação e devem fazer, porque isso é uma atividade inerente a atividade de gestão. Uma das funções do administrador é avaliar e fazer monitoramento. Existem outras agências como o Ministério do Planejamento por intermédio do Ipea, etc., porque o Ipea pode fazer uma avaliação na área de transporte, saúde, educação, etc., sem ser o Ministério do Transporte, Saúde e Educação. sic. (Metodologia do processo de implementação da ANOp no TCU. TCU, 30 jan 15. Entrevista concedida a Helayne Rodrigues da Silva).

.... MDS eu acho que por conta do bolsa família que foi... que é um programa até hoje.... eu acho que ele próprio se estruturou pra se avaliar muito né? Então tem muito avaliação, tem muito dado, tem muito informação. sic.

${ }^{66}$ SAGI - Secretaria de Avaliação e Gestão da Informação do Ministério do Desenvolvimento Social e Combate à Fome. 
(Metodologia do processo de implementação da ANOp no TCU. TCU, 28 jan 15. Entrevista concedida a Helayne Rodrigues da Silva).

Avaliação e monitoramento são essenciais. É uma ferramenta de gestão. Quer dizer, em primeiro lugar, é o próprio gestor deve monitorar e avaliar o seus programas as suas atividades. Bom, o Ministério do Planejamento se esforça e vem se esforçando pra criar esse ambiente né? Tem gespublica ${ }^{67}$ sic.(Metodologia do processo de implementação da ANOp no TCU. TCU, 4 fev 15. Entrevista concedida a Helayne Rodrigues da Silva).

Em levantamento ${ }^{68}$ do Tribunal sobre os sistemas de monitoramento e avaliação da administração direta do Poder Executivo, publicado em 2011, constatou-se que 15 dos 25 órgãos setoriais (Ministérios) que responderam à pesquisa não haviam implementado sistemas avaliativos próprios para o monitoramento e avaliação de seus programas.

Outro agravante se refere ao Sistema de Monitoramento e Avaliação do PPA que não era capaz, segundo o documento ${ }^{69}$, de dar cumprimento às funções que lhe foram atribuídas, não obstante a sua normatização e estruturação em todos os níveis. (SERPA, 2006).

O relatório concluiu ainda que devido os diferentes níveis de organização e maturidade dos Ministérios e com as mudanças introduzidas pelo novo PPA (2012-2015) uma demanda maior de supervisão, coordenação e apoio emergiriam dos órgãos setoriais em relação ao órgão central de planejamento. O quadro abaixo mostra o quantitativo de avaliações realizadas pelos ministérios entre 2005 e 2009.

\footnotetext{
${ }^{67}$ A Secretaria de Gestão Pública - SEGEP, do Ministério do Planejamento, Orçamento e Gestão, revitaliza, em 2014, o Programa Nacional de Gestão Pública e Desburocratização - GESPÚBLICA, com a finalidade de fortalecer a gestão pública, tendo como premissa o Modelo de Excelência em Gestão Pública - MEGP. A estratégia para a implantação de um modelo referencial de gestão pública é desenvolver ações de apoio técnico aos órgãos e entidades da Administração Pública Federal, a fim de mobilizar, preparar e motivar para a atuação em prol da inovação e da melhoria da gestão. http://gespublica.gov.br

${ }^{68}<$ http://portal2.tcu.gov.br/portal/page/portal/TCU/comunidades/programas_governo/areas_atuacao/administracao_p ublica>

69 Selma Maria Hayakawa Cunha Serpa. Auditora Federal de Controle Externo do Tribunal de Contas da União desde 1987; doutoranda e mestre em Administração pela Universidade de Brasília; especialista em Au- ditoria Governamental (ESAF/MF), Avaliação de Políticas Públicas (UFRJ) e Avaliação da Gestão Pública (ISC/TCU); graduada em Administração e Ciências Contábeis. Ex-Secretária de fiscalização e avaliação de programas governamentais do TCU (2003-2006), tendo exercido, ainda, as funções de diretora técnica e assessora.
} 
Tabela 1 - Quantidade de avaliações por Ministérios entre 2005 e 2009.

\begin{tabular}{|c|c|c|c|c|c|c|c|c|}
\hline Vinculação & 2005 & 2006 & 2007 & 2008 & 2009 & $\begin{array}{l}2005- \\
2007\end{array}$ & $\begin{array}{l}2008- \\
2009\end{array}$ & TOTAL \\
\hline Gabinete da Presidência da República & & & 1 & & & 1 & 0 & 1 \\
\hline Ministério da Agricultura, Pecuária e Abastecimento & 12 & 7 & 9 & 4 & 9 & 28 & 13 & 41 \\
\hline Ministério da Ciência e Tecnologia & 5 & 6 & 1 & 1 & 7 & 12 & 8 & 20 \\
\hline Ministério da Cultura & 6 & 2 & 2 & 3 & 5 & 10 & 8 & 18 \\
\hline Ministério da Defesa & 6 & 5 & 5 & 6 & 4 & 16 & 10 & 26 \\
\hline Ministério da Educação & 3 & 2 & 4 & 3 & 3 & 9 & 6 & 15 \\
\hline Ministério da Fazenda & 3 & 2 & 4 & 3 & 1 & 9 & 4 & 13 \\
\hline Ministério da Integração Nacional & 3 & 1 & 4 & & 5 & 8 & 5 & 13 \\
\hline Ministério da Justiça & 8 & 4 & 9 & 3 & 7 & 21 & 10 & 31 \\
\hline Ministério da Previdência Social & & & & 3 & 3 & 0 & 6 & 6 \\
\hline Ministério da Saúde & 11 & 12 & 12 & 5 & 4 & 35 & 9 & 44 \\
\hline Ministério das Cidades & 2 & 1 & 1 & 4 & 6 & 4 & 10 & 14 \\
\hline Ministério das Comunicações & 3 & 2 & 1 & 2 & 2 & 6 & 4 & 10 \\
\hline Ministério das Relações Exteriores & 3 & & 3 & 4 & 2 & 6 & 6 & 12 \\
\hline Ministério de Minas e Energia & 3 & 4 & 3 & 8 & 13 & 10 & 21 & 31 \\
\hline Ministério do Desenvolvimento Agrário & 2 & 2 & 2 & 1 & 4 & 6 & 5 & 11 \\
\hline Ministério do Desenvolvimento Social e Combate à Fome & 9 & 4 & 4 & 4 & 5 & 17 & 9 & 26 \\
\hline $\begin{array}{l}\text { Ministério do Desenvolvimento, } \\
\text { Indústria e Comércio Exterior }\end{array}$ & 5 & 3 & 3 & 6 & 5 & 11 & 11 & 22 \\
\hline Ministério do Esporte & 3 & 4 & 3 & 2 & 3 & 10 & 5 & 15 \\
\hline Ministério do Meio Ambiente & 15 & 7 & 8 & 3 & 9 & 30 & 12 & 42 \\
\hline Ministério do Planejamento, Orçamento e Gestão & 5 & 2 & 7 & 2 & 3 & 14 & 5 & 19 \\
\hline Ministério do Trabalho e Emprego & 6 & 3 & 4 & 5 & 7 & 13 & 12 & 25 \\
\hline Ministério do Turismo & 2 & 1 & & 1 & 2 & 3 & 3 & 6 \\
\hline Ministério dos Transportes & 2 & 3 & 5 & & 5 & 10 & 5 & 15 \\
\hline Ministério Público da União & & & & & 1 & 0 & 1 & 1 \\
\hline Presidência da República & 1 & 2 & 1 & 1 & 2 & 4 & 3 & 7 \\
\hline Secretaria Especial de Aquicultura e Pesca & 1 & & 1 & 1 & 1 & 2 & 2 & 4 \\
\hline $\begin{array}{l}\text { Secretaria Especial de Políticas de } \\
\text { Promoçăo da Igualdade Racial }\end{array}$ & 1 & 1 & & 1 & 1 & 2 & 2 & 4 \\
\hline Secretaria Especial de Politicas para as Mulheres & & & & & 2 & 0 & 2 & 2 \\
\hline Secretaria Especial dos Direitos Humanos & 3 & 2 & 2 & & 8 & 7 & 8 & 15 \\
\hline TOTAL & 123 & 82 & 99 & 76 & 129 & 304 & 205 & 509 \\
\hline
\end{tabular}

Fonte: Questionário de Avaliação Anual de Programas - PPA 2005/2009.

Embora mencionada na entrevista como um esforço positivo do Poder Executivo em aprimorar a gestão pública, a GESPÚBLICA foi objeto de auditoria operacional em 2014 e sofreu severas críticas do Tribunal conforme nota explicativa do próprio órgão:

O Tribunal de Contas da União (TCU) realizou auditoria na Secretaria de Gestão Pública (Segep), do Ministério do Planejamento (MP), para avaliar a capacidade de atuação do órgão como indutor do aperfeiçoamento da gestão pública. Foram avaliados a execução orçamentária dos recursos destinados ao aperfeiçoamento da gestão pública entre 2009-2014 e o desempenho dos principais instrumentos indutores da excelência na atuação do governo, como o Comitê do Programa Nacional de Gestão Pública e Desburocratização (GesPública), o Modelo de Excelência em Gestão Pública (MEGP) e as novas tecnologias e instrumentos de gestão que visam à melhoria da gestão pública. O relatório do TCU apontou falta de monitoramento, avaliação e incentivo de mecanismos de melhoria da gestão. Outro problema identificado foi a baixa taxa de adesão ao MEGP, ao GesPública e aos instrumentos indutores da excelência na gestão. Um dos pontos negativos destacados pelo relator do 
processo, ministro Raimundo Carreiro, foi a ausência de constituição válida do Comitê Gestor do GesPública. Segundo o ministro, as atribuições do Comitê não estão sendo desempenhadas, pois "o último registro de atuação foi de novembro de 2010". O ministro ainda alertou para a necessidade de adoção de medidas. "Urge a adoção de providências para evitar a má utilização dos recursos federais; a análise da adequação da gestão pública deve ser aprofundada", concluiu Carreiro. O TCU deu ciência à Casa Civil da Presidência da República e à Controladoria-Geral da União acerca das irregularidades e recomendou à Casa Civil que corrija as irregularidades mencionadas e que reavalie os modelos de adesão voluntária ao GesPública. $(T C U, 2015)^{70}$.

Outra observação manifestada nas conversas relaciona à necessidade de autoavaliação do Executivo, diz respeito aos estágios da política pública não serem muitas vezes respeitados de uma forma geral. Segundo um dos entrevistados não há projetos pilotos, não há reflexões sobre a racionalização de gastos, de redesenho de política e de eficiência. O aperfeiçoamento do desenho dos programas e a criação de indicadores claros é uma preocupação presente:

A gente ainda tem muitas áreas do Governo que não têm meta, que não tem indicador de desempenho né? Vou te dar um exemplo: a área de esporte. são indicadores meio confusos, são metas meio... que não te permitem avaliar resultado. Por exemplo, quantos municípios brasileiros têm um conselho de esporte? Ah o conselho de esporte é uma coisa importante pra política e tal, é... mas seria um... um pré-requisito né? E aí poucos municípios brasileiros tem um conselho de esporte, pra um país tão grande...Os primeiros trabalhos de auditoria de desempenho, tavam muito voltados até pra criação de indicadores. A gente estimulando, incitando, recomendando que os órgãos tivessem o trabalho pra criar uma cultura de indicador de desempenho, de meta, até pra gente poder avaliar. Muitas vezes você vai avaliar uma política que não tem nada. sic. (Metodologia do processo de implementação da ANOp no TCU. TCU, 4 fev 15. Entrevista concedida a Helayne Rodrigues da Silva).

O esforço que houve inclusive há alguns anos com o apoio do Ipea, que foi da... da... Cassiolato, Martha Cassiolato que foi aquela que eles chamaram de marco lógico, modelo lógico. Era uma adaptação do modelo lógico, mas que foi exatamente pra permitir que todas os programas de governo tivessem uma... uma... uma estrutura que permitisse monitoramento e avaliação, desenvolvimento de indicadores pra monitorar e avaliar. sic. (Metodologia do processo de implementação da ANOp no TCU. TCU, 28 jan 15. Entrevista concedida a Helayne Rodrigues da Silva).

Outro vínculo importante e protagonista de reflexões é a relação do Tribunal com a Controladoria Geral da União - CGU. Embora incipiente, consta-se questionamentos se o papel de avaliador de políticas públicas deve ser realizado pelo controle interno ou externo:

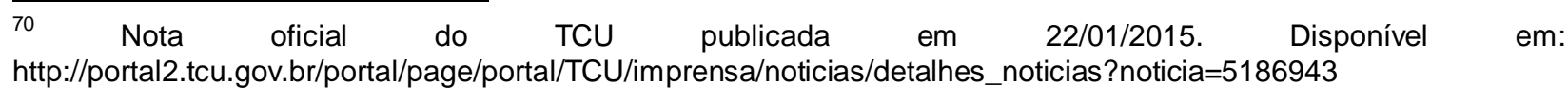


Olha, eu acredito que outras instituições tem que fazer isso. O próprio controle interno tem que fazer esse trabalho. Quer dizer, a CGU tem que fazer esse trabalho, o Ministério do Planejamento. Nos órgãos de controle interno mais especificamente na CGU acham que esse trabalho tem que ser feito por eles. Que eles é que tem que fazer auditoria operacional e o TCU tem que julgar. Então a gente tem uma discussão a respeito de sobreposição de tarefas do órgão de controle externo com o órgão de controle interno. sic. (Metodologia do processo de implementação da ANOp no TCU. TCU, 4 fev 15. Entrevista concedida a Helayne Rodrigues da Silva).

Apesar de se observar uma evolução de fatores considerados frágeis, em 2003, emerge a atual necessidade de fortalecer vínculos nacionais não mencionados anteriormente com Entidades que não participam da esfera de controle, principalmente, o Executivo.

Uma grande limitação da presente pesquisa foi exatamente não ter contatos com entidades do Poder Executivo que pudessem contra argumentar as informações levantadas neste trabalho. Em virtude da grande importância desta variável com este ator específico, ressalta-se a necessidade de extensão de trabalhos futuros neste ponto específico.

\subsubsection{Recursos}

Por entender que os Recursos abarcam o conceito de Estrutura Interna, na pesquisa foi utilizado essas variáveis com um único indicador que abrange as entradas financeiras, humanas, físicas e tecnológicas disponíveis a consecução dos objetivos organizacionais, sendo dois os marcos referentes à variável de recursos em 2005:

- O primeiro marco da estrutura e alocação específica de recursos para a atividade de auditoria operacional foi à criação da Secretaria de Métodos Aplicados e Suporte à Auditoria-Seaud;

- O segundo marco foi a alocação de recursos financeiros no Projeto de Cooperação Técnica com o Reino Unido - CERDS (Controle Externo com foco na Redução da Desigualdade Social .

De acordo com levantamentos atuais, durante a década de 2004-2014, a estrutura interna do Órgão sofreu modificações significativas, como a extinção da SEAUD, a criação da 
SEPROG- Secretaria de Fiscalização e Avaliação de Programas de Governo e a especialização das secretarias ${ }^{71}$.

A SEPROG deu continuidade ao trabalho desenvolvido pela SEAUD, concentrando a realização de auditoria de natureza operacional em sua unidade. Essa questão de concentração de trabalho devido à necessidade de conhecimentos específicos suscitou na pesquisa anterior reflexões quanto ao volume total de recursos destinados pelo TCU para auditoria operacional. Na visão dos entrevistados da época, não havia crescido o número de recursos em virtude da concentração dos trabalhos em uma única unidade.

Esta estrutura centralizadora sofreu mudanças consideráveis em 2013, com extinção da SEPROG e criação da SEMEC ${ }^{72}$ (Secretaria de Métodos), resultado da divisão das secretarias do Tribunal por temas abarcados no Plano Plurianual - PPA e a preocupação com a guarda de técnicas e metodologias aplicadas a auditoria operacional.

Em paralelo, ainda hoje, outro fator proeminente ainda é o recurso humano especializado. A especialização dos indivíduos ainda é mencionada como fator influente para o aumento do número de auditorias operacionais no Tribunal:

- Auditoria operacional é uma auditoria que requer um conhecimento cumulativo, quer dizer, quanto mais você faz, mais você adquire competência "pra" fazer. Como ela é uma auditoria que utiliza ferramentas da pesquisa social, então a formação tradicional do auditor não agrega muito pra auditoria operacional. Agrega o olhar, agrega a capacidade crítica, essa questão. Então ele exige uma capacitação minuciosa e vamos dizer assim, recorrente do corpo técnico do tribunal... Então uma dificuldade que o Tribunal tem é que ainda... ele ainda não tem todo o seu corpo técnico ou boa parte do seu corpo técnico capacitado pra fazer esse tipo de auditoria. sic. (Metodologia do processo de implementação da ANOp no TCU. TCU, 28 jan 15. Entrevista concedida a Helayne Rodrigues da Silva).

- hoje é a questão de você manter a qualidade, treinamento, profissionalização, manter a qualidade, que foi difundida assim. Antigamente você tinha uma unidade que só fazia isso, e, hoje, você tem dois anos que isso foi expandido para todo, "né"! Então você garantir que esses trabalhos sejam feitos com qualidade é o maior desafio, na minha opinião. sic. (Metodologia do processo de implementação da ANOp no TCU. TCU, 28 jan 15. Entrevista concedida a Helayne Rodrigues da Silva).

- Então eu diria a transmissão desse conhecimento "né"?... E esse é um conhecimento muito dinâmico e que exige uma aplicação muito prática. Então existe um risco muito sério das pessoas...de você não ter esse núcleo de

\footnotetext{
${ }_{71}^{71}$ Ver anexo com a estrutura atual do TCU.

72 Embora esta secretaria não possa ser visualizada ainda no novo organograma no TCU, todos os auditores entrevistados já mencionam o nome e a atividade desta nova secretaria como uma área de "tutoria" e guarda de metodologias.
} 
referência e esse conhecimento ficar diluído e acabar sufocado na instituição. sic. (Metodologia do processo de implementação da ANOp no TCU. TCU, 28 jan 15. Entrevista concedida a Helayne Rodrigues da Silva).

Questionados novamente em 2015 se a auditoria operacional estava difundida por todo o TCU, ou seja, se todas as unidades técnicas a executavam de forma rotineira, os entrevistados confirmaram o entendimento anterior que as demais unidades não conseguiam realizar auditorias operacionais de forma rotineira devido aos fatores: tempo, conhecimento e pessoal:

E aqui no Tribunal ainda tem uma resistência sabe? Pra trabalhos mais longos, muita pesso... muitas pessoas, eles fazem auditorias com duas pessoas normalmente e em três meses. sic. (Metodologia do processo de implementação da ANOp no TCU. TCU, 3 fev 15. Entrevista concedida a Helayne Rodrigues da Silva).

Segundo sistema de registro do TCU, a proporção das auditorias operacionais é ainda inferior a quantidade de auditorias conformidade, embora seja observada que esta tendência vem mudando nos últimos dois anos, período que corresponde à nova estrutura organizacional do Tribunal onde as secretarias estão separadas por temas.

Tabela 2: Tabela com o quantitativo de Auditorias por ano no TCU.

\begin{tabular}{|c|c|c|c|c|c|c|}
\hline $\begin{array}{c}\text { Modalidades de } \\
\text { Fiscalização }\end{array}$ & 2009 & 2010 & $\mathbf{2 0 1 1}$ & $\mathbf{2 0 1 2}$ & $\mathbf{2 0 1 3}$ & $\mathbf{2 0 1 4}$ \\
\hline Conformidade & 102 & 602 & 522 & 575 & 279 & 259 \\
\hline Operacional & 71 & 46 & 44 & 68 & 72 & 141 \\
\hline
\end{tabular}

FONTE: SEMEC-TCU, data atualização 28/01/2015

A auditoria Operacional leva em torno de quatro a seis meses para ser concluída, exigindo, no mínimo, uma equipe de três a cinco pessoas divididas em coordenador e auditores. Estes critérios quando observados em sua plenitude alavancam oportunidades de realização de outras modalidades de auditoria em detrimento da auditoria operacional: 
- Auditoria operacional demanda, na maioria das vezes, tempo. E também equipes multidisciplinar, muitas vezes. $\mathrm{Na}$ auditoria operacional geralmente são equipes maiores de no mínimo três. Então, significa que você precisa de mais recursos pra fazer. Então, no tempo em que você faria quatro, cinco auditorias de conformidade, você "tá" fazendo uma operacional colocando quatro, cinco servidores pra fazer um trabalho de quatro, seis meses ou às vezes até mais. Significa que você tem uma demanda de recurso "pras" auditorias operacionais maiores... Então muitas unidades aqui, às vezes gostariam de fazer mais trabalhos, mais trabalhos dessa natureza e elas tem... não conseguem porque tem outras demandas. Quer dizer, é concorrente, "né"? A auditoria operacional é concorrente com outras tarefas da unidade. sic. (Metodologia do processo de implementação da ANOp no TCU. TCU, 28 jan 15. Entrevista concedida a Helayne Rodrigues da Silva).

- Porque você precisa de tempo, precisa de uma quantidade de pessoas que normalmente as outras auditorias não demandam. Às vezes você consegue fazer um trabalho que não é operacional num tempo mais curto, com menos gente. Tem a questão do perfil "né"? porque você muda o assunto o tempo todo e quando você começa um assunto você começa do zero. Então você tem que começar a estudar aquele assunto. sic. (Metodologia do processo de implementação da ANOp no TCU. TCU, 3 fev 15. Entrevista concedida a Helayne Rodrigues da Silva).

- quando não tem muito tempo pra executar, o secretário não dá muito tempo. E a auditoria de desem... operacional precisa de mais tempo. É da lógica da auditoria a gente até a gente conhecer o programa direito tem que ter mais tempo. E eu acho que um dos problemas é não ter tempo. Outra coisa, alguns secretários acham que auditoria operacional tem menos importância, então coloca auditores menos capacitados ou não capacitados pra fazer. sic. (Metodologia do processo de implementação da ANOp no TCU. TCU, 4 fev 15. Entrevista concedida a Helayne Rodrigues da Silva).

Como já mencionado, em contraste a este cenário, observa-se nas entrevistas atuais o reconhecimento de que esta concorrência vem reduzindo nos últimos anos. São apontados dois fatores fundamentais nesta mudança de paradigma: A assimilação de técnicas aplicadas a ANOp em outras modalidades de auditoria e a especialização das unidades técnicas responsáveis pelas fiscalizações distribuída em temas como Educação, Saúde, Desenvolvimento Econômico e Administração do Estado:

- Parte das técnicas que o Tribunal utiliza hoje em auditoria foram trazidos e incorporados via auditoria operacional. Mesmo hoje técnicas que você utiliza pra conformidade foram trazidas pela auditoria operacional. E hoje tem um fenômeno interessante que também é inevitável. Hoje, às vezes, você não consegue diferenciar se você trabalha com conformidade ou resultados. Às vezes, você tem trabalhos que parte é operacional, parte é conformidade, sem que fique muito claro, assim... "né"... Às vezes, você tem um que predomina, mas tem elementos de outro. sic. (Metodologia do processo de implementação da ANOp no TCU. TCU, 4 fev 15. Entrevista concedida a Helayne Rodrigues da Silva). 
- Eu desconfio de alguns dos dados que a gente tem lá cadastrado... que cadastra como ANOp, mas não são ANOp. A matriz de achados é uma... Uma criação nossa. A gente pegou matriz de planejamento do $\mathrm{GAO}^{73}$ e adaptou. Eu sei que vários países da América Latina não usam. Passaram a usar depois do Tribunal. sic. (Metodologia do processo de implementação da ANOp no TCU. TCU, 4 fev 15. Entrevista concedida a Helayne Rodrigues da Silva).

- A gente é claro que trouxe muita coisa do GAO e do $N O^{74}$. O que a gente fez foi dar a nossa visão, quer dizer, os nossos exemplos de como a gente usou aquelas ferramentas... A medida que a gente ia implementando e ia praticando a auditoria, a gente ia enriquecendo os documentos técnicos, "né"? sic. (Metodologia do processo de implementação da ANOp no TCU. TCU, 28 jan 15. Entrevista concedida a Helayne Rodrigues da Silva).

-A gente começou a trabalhar é... com as matrizes pra que a gente tivesse uma forma de olhar ou planejamento ou resultado de uma auditoria num único documento. $\mathrm{E}$ a partir daí direcionar os esforços da equipe pra desenvolver os trabalhos. sic. (Metodologia do processo de implementação da ANOp no TCU. TCU, 28 jan 15. Entrevista concedida a Helayne Rodrigues da Silva).

-A gente acabou absorvendo diversas técnicas com origem na área de administração, e fazendo uma adaptação para aplicar na avaliação de programa de governo. A matriz de achados é uma criação do TCU. sic. (Metodologia do processo de implementação da ANOp no TCU. TCU, 4 fev 15. Entrevista concedida a Helayne Rodrigues da Silva).

A nova estrutura sustentada em eixos temáticos do Tribunal estende a auditoria operacional para todas as secretarias numa tentativa de elaborar análises mais aprofundadas sobre as atividades do governo:

A questão do PPA, por exemplo, influenciou bastante o TCU, há dois anos, quando foram criadas áreas de coordenação. Então foram criadas quatro coordenações é... e que tão intimamente ligadas ao PPA, que são quatro eixos lá. Uma área social, uma área de desenvolvimento, uma área de infraestrutura e uma área de administração. Então essa organização interna em coordenações "tá" diretamente ligada ao PPA e assim, numa tentativa de que do TCU possa, ao final do... dos quatro anos do PPA dizer: olha o PPA se... se dispunha a fazer isso e entregou isso. sic. (Metodologia do processo de implementação da ANOp no TCU. TCU, 4 fev 15. Entrevista concedida a Helayne Rodrigues da Silva).

Essa nova estrutura exigiu que a antiga SEPROG fosse remodelada, sendo hoje a SEMEC (Secretaria de Métodos), que dentre suas principais responsabilidades estão assegurar que as práticas de auditoria sigam as metodologias adequadas:

\footnotetext{
${ }^{73}$ U.S. Government Accountability Office. http://www.gao.gov

${ }^{74}$ U.K. National Audit Office http://www.nao.org.uk
} 
Eu acho que foi uma ótima ideia a especialização por tema, porque pra você fazer à avaliação a auditoria operacional você tem que ter duas habilidades, pelo menos, que é a habilidade de pesquisa em Ciências Sociais e o conhecimento do objeto que você "tá" auditando. Quando a auditoria operacional estava centralizada na antiga SEPROG, o pessoal aqui ele se especializou em métodos de pesquisa. Mas eles... Cada trabalho eles tinham que partir quase do zero no conhecimento do objeto. Então não eram especialistas em educação, não eram especialistas em saúde. Eram auditores. Agora não. Agora existe uma tendência de você aliar o conhecimento da área com o conhecimento é metodológico soube como fazer a auditoria. sic. (Metodologia do processo de implementação da ANOp no TCU. TCU, 30 jan 15. Entrevista concedida a Helayne Rodrigues da Silva).

Os auditores questionados acreditam que esta nova estrutura maximiza tanto a utilização de recursos humanos, quanto à estrutura física do Tribunal visto que a utilização da ANOp, segundo eles, contribui para o maior conhecimento do objeto:

Você acaba especializando as secretarias num assunto, mas não é suficiente você separá-las por nome pra que elas conheçam o objeto do nome delas "né"? Dizer que essa é a secretaria que cuida da área de saúde, mas você não dá os meios pra ela se estruturar, pra ela conhecer a questão... o assunto saúde... ajuda, mas é meio... é metade do caminho. Você precisa dotar aquela secretaria, você precisa fazer trabalhos que permitam a secretaria conhecer o assunto. Se você continuar fazendo os trabalhos que você fazia sem profundidades, sem ir a campo, sem visitar os Ministérios, sem ir nos estados conhecer como é que aquela política é executada na ponta. sem conversar com os beneficiários, aqueles que usam os serviços enfim. Se você não fizer esse outro lado, você não vai conseguir conhecer o seu assunto. e se você não conhece o assunto, aí fica difícil. Mudar simplesmente o nome não resolve o problema "né"? sic. (Metodologia do processo de implementação da ANOp no TCU. TCU, 28 jan 15. Entrevista concedida a Helayne Rodrigues da Silva).

Ficou claro também na pesquisa que a chamada auditoria operacional é uma forma de Avaliação. Todo seu referencial teórico e grande número de suas técnicas são baseados nas ciências sociais e avaliação de projetos:

Quer dizer, a gente fala de avaliação de programa porque é uma disciplina, um método de fazer avaliação, mas a auditoria operacional na verdade é a forma como as instituições de controle fazem avaliações de programa. sic. (Metodologia do processo de implementação da ANOp no TCU. TCU, 28 jan 15. Entrevista concedida a Helayne Rodrigues da Silva).

Como uma ferramenta de avaliação sofre com fatores já ressaltados pela literatura como inerente a atividade, Worthen ressalta que além de preocupações orçamentárias aplicadas aos 
projetos, sempre que pessoas que não são especialistas em avaliação conduzem ou ajudam nas tarefas, o avaliador assume responsabilidades singulares que não podem ser negligenciadas como orientação, treinamento e controle. No entendimento do autor:

Os membros da equipe de avaliação que não tem treinamento especializado nem experiências relevantes, precisam de orientação no tocante a natureza do estudo, e suas finalidades e ao papel que serão chamados a desempenhar. Precisam entender suas responsabilidades no sentido de realizar suas tarefas aviatórias com qualidade e em tempo hábil. (WORTHEN, 2004, p. 68).

Outra dificuldade encontrada na literatura e constada nas entrevistas é a falta da qualidade de base de dados avaliados. Quanto mais informações precisarem ser geradas pelo avaliador, mais dispendiosa será a avaliação. (WORTHEN, 2004, p.319). Segundo os entrevistados a utilização de bases de dados do governo em alguns momentos se impõe como desafios, pois nem todas as instituições possuem o mesmo grau de qualidade e confiabilidade de seus dados:

Base de dados de alguma... eu sempre consegui e sempre tive acesso a boas bases. Trabalhei com base do INSS, do... desses dos aeroportos. Ministério do Esporte agora eu fiz o Minha Casa, Minha Vida. Mas tem alguns outros programas que não têm base... base de dados estruturadas assim "né"? sic. (Metodologia do processo de implementação da ANOp no TCU. TCU, 28 jan 15. Entrevista concedida a Helayne Rodrigues da Silva).

A equipe não consegue fazer muitas visitas né? Outra estratégia é fazer uma pesquisa eletrônica e aí você manda questionários você... quando você pode, você tenta descobrir e-mail né? Aí você manda eletrônico. Eu já fiz na auditoria das drogas, a gente mandou 7.000 envelopes. Aí a pessoa recebia e aquilo voltava a mão. Então você pensa ter que digitar todas aquelas... tudo bem eu mandei 7.000 e não voltaram 7.000, mas sei lá deve ter voltado 1.200, 1.500. Então assim, eram... foi um esforço muito grande. Sofre um pouco com a falta de informações, de bases de dados, dos gestores. As bases de dados não são muito confiáveis. então às vezes pra gente é... fazer... cruzamento de dados em que não dá muito certo, que essas bases não são muito confiáveis e também tem poucas pessoas aqui no Tribunal também capazes de fazer esses cruzamentos. Não é qualquer servidor que tem essa habilidade. A gente também... quando a gente faz pesquisa eletrônica, como por exemplo, os beneficiários né? Os e-mails não são confiáveis. Tem que melhorar essa questão das amostras pra gente poder fazer aferições mais... pra uma população de forma estatisticamente mais correta. sic. (Metodologia do processo de implementação da ANOp no TCU. TCU, 3 fev 15. Entrevista concedida a Helayne Rodrigues da Silva).

Assim, a explicação apresentada em 2003 para ausência de expansão da atividade de auditoria operacional relacionada à variável recurso, não se aplica mais ao caso. A 
concentração dos trabalhos de avaliação de programas na SEPROG e as auditorias operacionais direcionadas para órgãos impedindo a atribuição das outras secretarias foram tratadas pelo Tribunal mediante a nova estrutura temática, porém novos fatores ainda podem impedir a expansão do número de avaliações realizadas tais como o conhecimento técnico do novo corpo técnico do tribunal e a base de dados de trabalho externo do tribunal.

\title{
3.2.3. Legitimidade
}

A questão mais controversa do trabalho se refere à variável legitimidade. Em 2005, observou-se a existência de conflito entre os diferentes tipos de legitimidade apontados no modelo de Suchman:

\begin{abstract}
Enquanto que o fenômeno do isomorfismo atua no sentido de conferir legitimidade cognitiva, atuam outros fatores, ligados a cultura e ao ambiente institucional do país, que interferem na dimensão da legitimidade moral, resultando na continuidade da atividade em um nível secundário na organização analisada. (FREITAS, 2005).
\end{abstract}

A variável Legitimidade foi categorizada em três subconceitos: pragmática, moral e cognitiva. Essa tipologia desenvolvida por Mark Suchman em seu livro Managing legitimacy: strategic and institutional approaches ${ }^{75}$, define a Legitimidade como a "percepção generalizada ou suposição de que as ações de uma entidade são socialmente desejáveis, adequadas [...] dentro de algum sistema socialmente construído de normas, valores, crenças e definições".

A legitimidade pragmática gira em torno do interesse da organização sobre as respostas imediatas da percepção do seu público. Envolve as relações institucionais nos aspectos políticos, econômicos e sociais. Já a legitimidade moral reflete crenças de que a atividade executada promove o bem-estar da sociedade, portanto, é uma avaliação do comportamento ético da organização. E, finalmente, a legitimidade cognitiva envolve o apoio da organização como necessária ou inevitável com base em alguns conceitos culturais.

Na perspectiva institucional a legitimidade é também um elemento motivador da busca da conformidade de uma organização ou de seu isomorfismo, sendo o principal meio pelo qual as organizações conseguem obter e manter recursos.

\footnotetext{
${ }^{75}$ SUCHMAN, Mark C. Managing legitimacy: strategican dinstitutional approaches. Academy of Management Review, v. 20, n. 3, p. 571-610, 1995.
} 
Foi considerado em 2003, que os processos de aprendizagem combinado com o fator Liderança e a inserção do artigo 70 da Constituição Federal, conferiram legitimidade cognitiva e moral a atividade de auditoria operacional:

O fator legitimidade, por sua vez, seria a causa do influxo inicial de recursos e criação de estrutura para a realização de trabalhos de auditoria operacional e da manutenção de processos de aprendizagem que retro alimentam o ciclo da atividade. (FREITAS, 2005).

Em 2003, conclui-se que a legitimidade da ANOp no Tribunal ainda não era consenso comum. A legitimidade pragmática resultava da estratégia do órgão em verificar não somente a conformidade de processos, mas, também, os resultados dos programas públicos. Fatores isomórficos miméticos e coercitivos, como a criação de competência constitucional e o contato com instituições internacionais que já praticavam a auditoria operacional conferiram legitimidade cognitiva à atividade. Já a legitimidade moral era enfraquecida devido aos questionamentos internos que giravam em torno da objetividade e efetividade das recomendações emitidas na ANOp:

Toda essa discussão sobre os dois tipos de controle, ou mesmo as eventuais críticas à auditoria operacional é inexistente no discurso oficial do órgão e pouco evidenciada nos documentos oficiais. Não se critica abertamente a atividade, tampouco são adotadas ações para a sua efetiva expansão. (FREITAS, 2005, p. 98).

$\mathrm{Na}$ época, o embate interno entre duas correntes de pensamento sobre a visão da auditoria operacional não afetava a visão externa favorável ao trabalho. Essa visão positiva era oriunda da estratégia do órgão em atuar em conjunto com os gestores, como em uma consultoria:

Os trabalhos de auditoria operacional encontrariam boa aceitação externa em razão de fornecerem informações sobre os programas governamentais a gestores que, em virtude da realidade da administração pública brasileira não dispõem dessas informações. O trabalho em si de auditoria operacional também chamaria a atenção para o programa, divulgando suas carências de modo a aumentar a possibilidade de que elas sejam sanadas. (FREITAS, 2005, p. 120).

Foi ressaltada na época que um dos fatores que influenciavam as opiniões era a diferença entre o ambiente em que a auditoria operacional era executada nos países de origem e o vigente no Brasil: 
Segundo os entrevistados, nos Estados Unidos, Canadá ou na Inglaterra o parlamento exerce realmente uma fiscalização sobre o emprego dos recursos públicos, a continuidade administrativa é maior, existem indicadores de desempenho e estatísticas em muito maior quantidade, há uma maior cobrança sobre os resultados da ação governamental e os trabalhos que avaliam resultados são valorizados, sendo objeto de telejornais em horário nobre, situações bem diferentes da realidade vigente em nosso país. (FREITAS, 2005, p.103).

Em leituras recentes, verifica-se que a legitimidade pragmática fortaleceu suas bases na década de 2004-2014, todos os discursos e documentos oficiais do Tribunal pesquisados reconstroem a figura da instituição e do seu papel na sociedade de uma forma mais abrangente, não sendo responsável apenas pelo o controle de fraudes e gastos públicos, sendo também parte de suas competências constitucionais contribuir para transparência, melhoria da gestão e do desempenho da Administração Pública:

Então as Entidades de Fiscalização Superior na sociedade e isso é o que elas querem fazer pra sociedade é dar transparência no uso de recursos públicos. Então ela usa diversos meios pra trabalhar essas questões de transparência, Accountability ${ }^{76}$, de prestação de contas a sociedade. Os processos formais de análise das contas né? $\mathrm{E}$ as fiscalizações tá? $\mathrm{E}$ então esses são os processos pra que você obtenha as informações e elas tem também, meios de que fazer com que essas informações cheguem a sociedade. sic. (Metodologia do processo de implementação da ANOp no TCU. TCU, 28 jan 15. Entrevista concedida a Helayne Rodrigues da Silva).

De combate á corrupção né? De... E também de análise das políticas públicas. A gente faz trabalhos pra ver como que tá a aplicação dos recursos públicos nas políticas públicas. Se isso tá gerando eficiência, eficácia, efetividade. sic. (Metodologia do processo de implementação da ANOp no TCU. TCU, 3 fev 15. Entrevista concedida a Helayne Rodrigues da Silva).

Guardiões da transparência, incentivadores da boa gestão, da probidade administrativa. Elas fazem um trabalho de controle, vamos dizer assim, externo, então seria de alguém neutro que olha pros resultados da ação do governo e dá opinião isenta, "né", sobre essas atividades, faz recomendações de uma maneira independente de quem tá de plantão no governo. sic. (Metodologia do processo de implementação da ANOp no TCU. TCU, 30 jan 15. Entrevista concedida a Helayne Rodrigues da Silva).

O olhar dos auditores sobre o papel da Entidade Fiscalização na Sociedade reflete, em sua maioria, o Plano Estratégico (PET) do TCU 2011-2015. O documento atualizado e

\footnotetext{
${ }^{76}$ A tradução do termo Accountability é frequentemente associada ao termo "responsabilização" em português, normalmente aplicada aos domínios da política e da administração, como por exemplo, em temáticas relacionadas à Governança.
} 
sancionado por meio da portaria - TCU $n^{\circ} 160$, de 28 de Junho de 2011, trouxe como luz aos trabalhos:

Negócio: Controle externo da Administração Pública e da gestão dos recursos públicos federais.

Missão: Controlar a Administração Pública para contribuir com seu aperfeiçoamento em benefício da sociedade.

Visão: Ser reconhecido como instituição de excelência no controle e no aperfeiçoamento da Administração Pública. (PLANO ESTRATÉGICO 20112015/TCU, p. 45).

De acordo com o PET o controle da administração pública transcende a conformidade dos processos e objetiva fornecer benefícios para sociedade por intermédio do aperfeiçoamento da gestão pública. Os conceitos como governança, transparência e impacto social foram incluídos na seara dos trabalhos da auditoria operacional:

Porque os programas de governo tão cada vez mais transversais. São raros os programas que tão num ministério só, fechadinho. Com auditoria operacional a gente entende melhor o programa e consegue atuar melhor. Até pra fazer a de conformidade. Todo mundo fala que quando começa a fazer... o pessoal das Secretarias especializadas agora, eles faziam auditoria há muitos anos, só que não conheciam sua clientela. Agora... conhecendo o... fazendo auditoria operacional eles falam: agora é que eu tô conhecendo qual é a clientela. E fica mais fácil pra eles fazer até a de regularidade. Então eu acho que a gente tem que caminhar pra fazer cada vez mais... é... auditoria operacional lá no Tribunal e... em programas transversais, programas sistêmicos. A gente tá indo pro um "que" de governança também. sic. (Metodologia do processo de implementação da ANOp no TCU. TCU, 4 fev 15. Entrevista concedida a Helayne Rodrigues da Silva).

Em 2013, entrevistado pela revista do IBRACON $^{77}$, o recém empossado presidente do TCU, João Augusto Ribeiro Nardes, afirmou:

A governança traduz um conceito relativamente novo, que tem sua essência na capacidade de condução dos processos de formulação, execução e avaliação das políticas públicas integrando os mecanismos de gestão com vistas à eficácia e efetividade dos resultados almejados e da transparência dos processos. Para tanto, a sistematização do planejamento com a aplicação de conceitos modernos que possibilitem o controle institucional e social, notadamente a accountability da atuação administrativa, pode alavancar mudanças significativas no panorama administrativo brasileiro. (REVISTA TRANSPARÊNCIA, Junho 2013. Ano 3. Número 10).

\footnotetext{
77 Instituto dos Auditores Independentes do Brasil
} 
Outro fator relevante relacionado a variável Legitimidade Pragmática, foram as incorporações das metas do ODM (Objetivos de Desenvolvimento do Milênio) nas auditorias operacionais. Essas séries de metas socioeconômicas foram e estão sendo utilizadas pelo Tribunal como parâmetro de avaliação de alguns programas do governo brasileiro. Isso é o que declarou em nota oficial ${ }^{78}$ ao PNUD em novembro de 2004, a então secretária de Fiscalização e Avaliação de Programas de Governo (Seprog) do TCU, Selma Hayakawa (2005):

As Metas do Milênio são um compromisso assumido pelo governo brasileiro, que usa os programas como mecanismos que contribuam para cumprir esses compromissos. É fundamental divulgar as Metas para esse público, responsável pela estratégia de atuação das instituições de controle. A incorporação dos Objetivos na avaliação dos programas vai ao encontro de uma das tarefas do TCU, que é contribuir para a melhoria da prestação do serviço público. (SERPA, 2005).

Todos esses valores observados na legitimação pragmática foram vetores importantes na consolidação da legitimidade cognitiva na última década. As conclusões de 2003 reconheciam no formalismo o mecanismo coercitivo principal para aceitação da mudança institucional, embora a competência constitucional ainda seja mencionada como ponto importante, ela não ocupa mais esse papel primordial:

Então assim muita gente acha que o Tribunal não deveria fazer, apesar de tá explícito lá na Constituição. Então eu particularmente acho que é uma ferramenta muito importante que os Tribunais de Contas têm e que a Constituição dá essa competência pra gente fazer esses trabalhos, que a gente tem que aproveitar da melhor forma possível. Tem até na Constituição que está lá: a auditoria de natureza operacional, que acabou indo parar lá na Constituição. Não consegui descobrir como isso foi parar na Constituição, mas o fato é que progressivamente isso foi se institucionalizando aqui com várias iniciativas, vários projetos. sic. (Metodologia do processo de implementação da ANOp no TCU. TCU, 30 jan 15. Entrevista concedida a Helayne Rodrigues da Silva).

O Art. 70 da Constituição Federal foi muito importante na operacionalização da ANOp, como assinalam Machado da Silva e Gonçalves apud Marcelo Milano ${ }^{79}$ p. 181 , o uso frequente de mecanismos coercitivos, tanto para a manutenção como para a transformação social, decorre da tradição patrimonialista em conjunção com os longos períodos autoritários que caracterizam o processo de formação sociocultural da sociedade brasileira.

\footnotetext{
${ }^{78}$ http://www.pnud.org.br/Noticia.aspx?id=3264

${ }^{79}$ Organizações, instituições e poder no Brasil/Organizadores: Marcelo Milano Falcao Vieira, Cristina Amélia Carvalho. - Rio de Janeiro: editora FVG, 2003.
} 
A Legitimidade Cognitiva envolve o apoio afirmativo a uma organização (SUCHMAN, 1995, p. 582). As regras que especificam quais os tipos de atores têm permissão para existir, que características estruturais apresentam, quais os procedimentos podem seguir, e quais os significados são associados a estas ações (RUEF E SCOTT, 1988:879, apud DOMINGUES 2011, p. 8).

A construção de novos construtos na sociedade brasileira ligados a equidade, racionalidade de bens públicos e o interesse de aproximação do Tribunal com a sociedade influenciaram os trabalhos na instituição. O entendimento da competência de avaliar políticas públicas extrapolou formalidades legais devido a uma mudança de paradigma, fruto também da renovação do quadro de funcionários:

É uma visão externa, primeira coisa, e é uma visão multidisciplinar. Primeiro que o Tribunal de contas ele tem gente aqui de... diversas formações né? A gente não tem uma exigência de formação $x, y$ ou $z$. Então você tem de dentista a filósofo, contador, advogado, administrador, economista e na medida do possível a gente tenta mesclar essas formações dentro dessa... desse trabalho de avaliação. Além de ser uma visão externa, uma visão ampla. sic. (Metodologia do processo de implementação da ANOp no TCU. TCU, 4 fev 15. Entrevista concedida a Helayne Rodrigues da Silva).

Não é uma questão apenas legal, mas internacionalmente, a accountability ela é vista como tendo a accountability de resultado e a accountability de conformidade. E se o negócio do Tribunal, no ponto de vista accountability, ele deve agir nas duas áreas. Não que seja de maneira igual. Pode dividir os seus esforços. Mais esforço numa área do que outra. Mas não pode acumular completamente auditoria operacional, porque senão fica falho a atuação do controle. $E$ existe uma demanda social por isso também. Então existe. Existe pessoas que tem uma formação mais jurídica que gostaria que o tribunal de contas virasse um órgão do poder judiciário. É uma demanda social para que o tribunal emita opinião independente sobre eficiência efetividade das políticas públicas e porque é uma obrigação constitucional. sic. (Metodologia do processo de implementação da ANOp no TCU. TCU, 28 jan 15. Entrevista concedida a Helayne Rodrigues da Silva).

TCU tem uma característica de ser uma... um órgão inovador.Teve uma pesquisa aqui há alguns anos, acho que 2008... 2007 - 2008, que foi perguntado pro público em geral, quem era o Tribunal de Contas da União, e só $2 \%$ da população tinha alguma ideia, dizia que sabia o que era o Tribunal de Contas da União. o que a gente sente mais é uma visão do Tribunal de Contas como um órgão é... Em que tá correndo atrás da corrupção. É como se o Tribunal de Contas fosse é... Até pelo nome, Tribunal, traz muito forte essa coisa da punição. a visão externa ela ainda é muito permeada por essa questão da sanção. Tem uma questão na literatura, de que essa questão de corrupção é problema da polícia. O Tribunal pode até ajudar encontrando alguma coisa, encaminhar pra polícia, mas a nossa função precípua não é esse combate ostensivo a corrupção. sic. (Metodologia do processo de implementação da ANOp no TCU. TCU, 4 fev 15. Entrevista concedida a Helayne Rodrigues da Silva). 
Havia, vamos dizer assim, um modelo mental de auditoria e mudar esse modelo mental pra uma outra forma de trabalho foi muito difícil. sic. (Metodologia do processo de implementação da ANOp no TCU. TCU, 28 jan 15. Entrevista concedida a Helayne Rodrigues da Silva).

O isomorfismo mimético de DiMaggio \& Powell revelado na pesquisa anterior, continua se manifestando no processo de aprimoramento dos procedimentos e arranjos estruturais implementados no Tribunal:

Ano passado houve um congresso da EUROSAI na Europa em que eles discutiram inovações em auditoria operacional. E uma delas deve ter na internet o congresso da EUROSAl do ano passado, de 2014. Eles usam a expressão analitics que são técnicas de data mining e auditoria preditivas. São todas técnicas utilizadas e que existe uma corrente na literatura que tá chamando de auditoria preditiva, que envolve dataminig e que eles falam analitics. São técnicas novas em... Que estão sendo utilizadas em auditoria operacional. sic. (Metodologia do processo de implementação da ANOp no TCU. TCU, 30 jan 15. Entrevista concedida a Helayne Rodrigues da Silva).

Sempre modernizar a auditoria operacional, Tirar esses preconceitos que existem com relação a ela. Adaptá-la pra que todas as secretarias possam fazer né? Porque a gente tem um método, mas esse método tem que ser revisitado sempre. sic. (Metodologia do processo de implementação da ANOp no TCU. TCU, 3 fev 15. Entrevista concedida a Helayne Rodrigues da Silva).

Eu acho que a direção é a gente tentar conseguir capitar os modismos. Agora o modismo é utilizar base de dados, que a gente já fazia, mas de uma forma mais ostensiva. sic. (Metodologia do processo de implementação da ANOp no TCU. TCU, 4 fev 15. Entrevista concedida a Helayne Rodrigues da Silva).

O Tribunal na última gestão tem tentado incluir e fazer trabalhos que acabam focando a governança. Então são temas que não eram trabalhados e que acabam... E que naturalmente vão gerando algum tipo de metodologia, alguma coisa... Mas muita coisa já é feita fora e aí o pessoa estuda como aquele... Como isso é feito, aplica uma técnica, testa um instrumento. sic. (Metodologia do processo de implementação da ANOp no TCU. TCU, 4 fev 15. Entrevista concedida a Helayne Rodrigues da Silva).

Enquanto uma corrente dentro do TCU defendia e ainda defende a auditoria operacional como uma atividade importante para o exercício do controle, outra corrente defende o controle de legalidade, em função do cenário de corrupção existente no país.

Mas assim, as pessoas questionam ainda tem pessoas dentro da casa que questionam a... não a qualidade do trabalho, mas a efetividade, se isso realmente gera benefícios né? se muita gente questiona se é realmente o papel do Tribunal fazer esse tipo de avaliação. Tem muita resistência com relação à aplicação do método também. Existem questionamentos pra fazer sobre o 
resultado como foi feito. sic. (Metodologia do processo de implementação da ANOp no TCU. TCU, 30 jan 15. Entrevista concedida a Helayne Rodrigues da Silva).

Essa questão da auditoria operacional ela não é totalmente aceita. Tem muita gente antiga ainda que não... Não participou... Que não aceitou essa modalidade. Que o direito administrativo ele não permite que o judiciário que os tribunais de Conta eles entrem na seara de conveniência e oportunidade. E o questionamento mais atual é se... Essa questão de tá aumentando muito a quantidade de trabalho operacional. Eu acho que esses questionamentos se deve ter, ele diminuiu com os resultados que foram apresentados nos últimos anos né? Então com o aperfeiçoamento da técnica, mais treinamento do pessoal, cada vez mais diminuiu esse questionamento. $O$ questionamento é a quantidade de trabalhos dessa natureza, que a gente deveria conseguir equilibrar um pouco mais é... sic. (Metodologia do processo de implementação da ANOp no TCU. TCU, 4 fev 15. Entrevista concedida a Helayne Rodrigues da Silva).

Muito desde o início, porque a introdução da... da auditoria operacional no TCU ela... ela foi feita num ambiente muito conservador e muito avesso à mudança. Assim, nós chamamos muita dificuldade de trabalhar questões que são básicas nas auditorias operacionais, que é o contato com o gestor. Porque o que eu mais ouço está relacionado com o rigor metodológico. Já ouvi sim questionamentos do TCU realizar na área de regulação de infraestrutura, questionamentos muito contundentes, que inclusive que... que geraram propostas de serciamento das competências do Tribunal nessa área. sic. (Metodologia do processo de implementação da ANOp no TCU. TCU, 30 jan 15. Entrevista concedida a Helayne Rodrigues da Silva).

Eu tenho conhecimento de... de boatos de pessoas que falam que não serve pra nada, que é consultoria, isso é trabalho do gestor, não é... não é uma coisa que o Tribunal deveria fazer. sic. (Metodologia do processo de implementação da ANOp no TCU. TCU, 4 fev 15. Entrevista concedida a Helayne Rodrigues da Silva).

Mesmo ainda existindo confrontos ideológicos internos, constata-se que os motivos embrionários das discussões perderam força nestes últimos anos em parte pela repercussão dos trabalhos e por outro lado, pelo desenvolvimento de metodologias que permitiram a produção de trabalhos mais objetivos e precisos.

Uma visão um pouco legalista de alguns colegas que tem uma formação, como eu digo, um modelo mental mais legal, não é que esteja errado, mas no campo da auditoria operacional, você precisa mais de flexibilidade. E muitas vezes se entende isso como uma falta de fundamentação, uma falta de evidencias, mas as evidencias na auditoria operacional são as mesmas de avaliação, ou seja, você tem que triangular informação, é diferente. Elas não tão baseadas em fatos e documentos. Elas se baseiam na observação, em diálogo com o gestor, em análises de... Informações analíticas de processos de gestão. $\mathrm{E}$ eu percebi isso não só aqui internamente, não só a crítica dos colegas. algumas críticas com certeza são válidas, tanto é que ao longo do tempo nós conseguimos melhorar a nossa... Trazendo mais informação quantitativa. Trabalhando melhor dados quantitativos. Isso deu muita credibilidade ao nosso 
trabalho. Claro sempre que você consegue dados quantitativos de qualidade e confiáveis e tal. sic. (Metodologia do processo de implementação da ANOp no TCU. TCU, 28 jan 15. Entrevista concedida a Helayne Rodrigues da Silva).

A evolução das recomendações emitidas na ANOp proporcionou o aumento no número de monitoramentos realizados pelo TCU e hoje, são uma prática comum que se segue logo após a conclusão da ANOp. Alguns programas como o Bolsa Família, além da avaliação inicial já sofreram três monitoramentos.

A auditoria tem um processo... Ela gera um processo que é o monitoramento. Você vai acompanhar o que foi recomendado no processo original. O meu primeiro trabalho foi... foi do tipo monitoramento. Programa Amazônia legal. sic. (Metodologia do processo de implementação da ANOp no TCU. TCU, 4 fev 15. Entrevista concedida a Helayne Rodrigues da Silva).

De acordo com Schuman o atrito entre as categorias de legitimidade geralmente acontece em grandes instituições em períodos de mudanças históricas. A legitimidade moral refletida em uma lógica pró-social fundamentada no interesse próprio pode tomar três formas: avaliação de resultados e consequências; avaliações de técnicas e procedimentos; as avaliações das categorias e das estruturas. Logo, a legitimidade moral de acordo com Suchman (1995) pode ser analisada por meio de evidenciações.

Quadro 14: Estratégias para a Legitimação

\begin{tabular}{|c|c|c|c|}
\hline \multirow{2}{*}{ Categorias } & \multicolumn{3}{|c|}{ Estratégias para a Legitimação } \\
\hline & Ganho & Manutenção & Reparação \\
\hline \multirow{3}{*}{ Moral } & $\begin{array}{c}\text { Adaptar-se aos ideiais } \\
\text { Produzir resultados adequados } \\
\text { Incorporar-se a instituições } \\
\text { Oferecer demonstrações } \\
\text { simbólicas }\end{array}$ & $\begin{array}{c}\text { Monitorar ética } \\
\text { Consultar as categorias } \\
\text { profissionais }\end{array}$ & $\begin{array}{l}\text { Desculpar/ } \\
\text { Justificar }\end{array}$ \\
\hline & $\begin{array}{l}\text { Selecionar o domínio } \\
\text { Definir as metas }\end{array}$ & $\begin{array}{l}\text { Favorecer a boa conduta } \\
\text { Monitorar a responsabilidade } \\
\text { Comunicar-se oficialmente } \\
\text { Estocar opiniões favoráveis }\end{array}$ & $\begin{array}{c}\text { Desassociar } \\
\text { Substituir } \\
\text { pessoal } \\
\text { Rever as práticas } \\
\text { Reconfigurar }\end{array}$ \\
\hline & $\begin{array}{c}\text { Persuadir } \\
\text { Demonstrar sucesso } \\
\text { Fazer proselitismo(trazer adeptos) }\end{array}$ & & \\
\hline
\end{tabular}

Fonte: Schuman, p. 600

De acordo com as considerações dos entrevistados, vários foram os resultados positivos para gestão pública alcançados mediante as auditorias operacionais. Porém, nesse ponto da pesquisa apresenta fragilidade por três motivos: a falta de casos de sucesso catalogados pelo 
Tribunal, falta de entrevista com auditores que discordam oficialmente da pratica da ANOp e a falta de registro das opiniões dos gestores que foram auditados pelo Tribunal.

Olha, você tem vários casos que poderiam ser citados aí de resultados positivos. Eu posso citar casos. No tribunal, é uma coisa que é uma falha nossa... É que a gente não fez sistematicamente uma avaliação desses benefícios em relação só à auditoria operacional. sic. (Metodologia do processo de implementação da ANOp no TCU. TCU, 4 fev 15. Entrevista concedida a Helayne Rodrigues da Silva).

De acordo com dados disponíveis no Tribunal, são mais de 400 auditorias que transitam entre os temas Administração Pública, Agricultura, Assistência Social, Ciência Tecnologia, Comunicações, Direitos da Cidadania, Direitos Humanos, Educação, Energia Elétrica, Esportes, Gestão Ambiental, Habitação, Saneamento e Urbanismo, Indústria, Comércio e Serviços, Organização Agrária, Previdência Social, Relações Exteriores, Saúde, Segurança Pública, Trabalho e Transporte.

O Tribunal na tentativa de minimizar este gap de informação criou em 2014 o FISC, um relatório sistêmico de função que compila em um único documento achados de várias auditorias operacionais de um determinado setor para subsidiar discussões com os órgãos responsáveis e excitar o controle social por intermédio da análise de fragilidades e possíveis riscos de uma área. Em 2014, dois relatórios foram apresentados FISCSAUDE e FISC Assitencia Social. Abaixo, pode-se ler o resumo deste relatório disponibilizado no website ${ }^{80}$ do Tribunal: Social)

O relatório sistêmico da função assistência social (FISC Assistência

O TCU fiscalizou a atuação do Ministério do Desenvolvimento Social (MDS), órgão responsável pela função em âmbito federal. Em 2013, o orçamento da assistência social foi de $\mathrm{R} \$ 64$ bilhões.

A política de assistência social no Brasil é feita principalmente com transferência direta de recursos. Os gastos são relativos a três programas de governo: i) Fortalecimento do Serviço Único de Assistência Social (SUAS), que corresponde a $56,4 \%$ dos gastos e inclui o programa Benefícios de Prestação Continuada (BPC); ii) o programa Bolsa Família (PBF), com 38,14\%; e iii) Segurança Alimentar e Nutricional, com 4,79\% dos recursos.

$\mathrm{Na}$ ocasião, entre os principais problemas destacados pelo tribunal estavam o risco a sustentabilidade fiscal do BPC e do Bolsa Família. O TCU destacou que os dispêndios com esses dois benefícios representaram 1,15\% do PIB, em 2013.

\footnotetext{
${ }^{80} \mathrm{http}: / /$ portal2.tcu.gov.br/portal/page/portal/TCU/imprensa/noticias/detalhes_noticias?noticia=5185458
} 
O PBF atende mais de 14 milhões de famílias e durante os últimos anos aumentou o quantitativo de famílias e dos valores transferidos. Contudo, o tribunal encontrou fragilidades como ausência de indicadores de porta de saída e a desatualização das linhas de pobreza oficiais. Estes fatores podem ter resultado em uma provável sobre avaliação dos indicadores que medem a superação da linha da pobreza no país.

Já o BPC beneficia aproximadamente 3,9 milhões de pessoas, o benefício paga um salário mínimo a portadores de deficiência e a idosos a partir de 65 anos. O TCU identificou fragilidades no programa como a auto declaração dos dados da renda e o não cruzamento dos dados com outras bases.

O tribunal também constatou falhas nos Centros de Referência de Assistência Social (CRAS) e nos Centros de Referência Especializados de Assistência Social (CREAS), unidades públicas estatais de abrangência municipal ou regional que realizam o trabalho social especializado a famílias e indivíduos em situação de risco. Foram verificados deficiência no controle e gestão de riscos, baixo nível de eficiência dos CRAS e dos CREAS.

Por outro lado, de acordo com o relator do processo, ministro-substituto Augusto Sherman Cavalcanti, "faz-se mister elogiar o trabalho do MDS, que vem, no decorrer de todo o período avaliado na presente fiscalização, buscando ampliar o acesso da população aos benefícios e serviços atinentes à Função Assistência Social".

$\mathrm{Na}$ época, o TCU fez recomendações para que o MDS promovesse estudos no sentido de identificar ações e indicadores visando auxiliar e incentivar a emancipação dos beneficiários do programa Bolsa Família e maior eficiência na atuação dos CRAS e os CREAS.

Sem intenção de esgotar o mapeamento de resultados e consequências alcançadas por meio dos trabalhos das auditorias operacionais já concluídos, listam-se alguns dos casos de sucessos retratados aleatoriamente durante as entrevistas. 
Quadro 15: Quadro de Auditorias Operacionais e seus resultados.

\begin{tabular}{|c|c|c|c|c|}
\hline Nome Programa & Objeto & Achados & Recomendação & Consequência \\
\hline $\begin{array}{l}\text { A política } \\
\text { Nacional de } \\
\text { Atenção } \\
\text { Oncológica }\end{array}$ & $\begin{array}{c}\text { Averiguar se a } \\
\text { estrutura da rede } \\
\text { de atenção } \\
\text { oncológica tem } \\
\text { possibilitado aos } \\
\text { doentes de } \\
\text { câncer acesso ao } \\
\text { diagnóstico e ao } \\
\text { tratamento da } \\
\text { doença }\end{array}$ & $\begin{array}{l}\text { Foi constatada carência de } \\
\text { instalações para atender a } \\
\text { demanda por serviços } \\
\text { relacionados à atenção } \\
\text { oncológica, que junto com } \\
\text { demora no diagnóstico da } \\
\text { doença e no tratamento } \\
\text { promovido pelo SUS, prejudica } \\
\text { as chances de cura dos } \\
\text { pacientes. O levantamento } \\
\text { constatou que o tempo } \\
\text { decorrido entre o diagnóstico } \\
\text { da doença e o início do } \\
\text { tratamento de quimioterapia ou } \\
\text { radioterapia ultrapassa trinta } \\
\text { dias. }\end{array}$ & $\begin{array}{l}\text { O TCU recomendou à SAS } \\
\text { que desenvolva plano com } \\
\text { objetivo de sanar as carências } \\
\text { existentes na rede de atenção } \\
\text { oncológica, que entre outras, } \\
\text { deve contemplar as seguintes } \\
\text { medidas: articulação com os } \\
\text { gestores locais do SUS com } \\
\text { vistas a considerar as } \\
\text { necessidades de estrutura da } \\
\text { rede de assistência } \\
\text { oncológica em cada unidade } \\
\text { da Federação }\end{array}$ & $\begin{array}{l}\text { Ampliação da oferta } \\
\text { de serviços e } \\
\text { definição de prazos } \\
\text { e metas } \\
\text { progressivos, até a } \\
\text { solução definitiva } \\
\text { das carências } \\
\text { existentes. }\end{array}$ \\
\hline $\begin{array}{c}\text { Proteção ao } \\
\text { Depoente } \\
\text { Especial }\end{array}$ & $\begin{array}{c}\text { Avaliar o } \\
\text { funcionamento e } \\
\text { o desempenho do } \\
\text { Serviço de } \\
\text { Proteção ao } \\
\text { Depoente } \\
\text { Especial }\end{array}$ & $\begin{array}{l}\text { O relacionamento entre } \\
\text { policiais e protegidos, pois um } \\
\text { dos motivos da solicitação do } \\
\text { MPF para que se realizasse a } \\
\text { auditoria foram reclamações de } \\
\text { maus tratos e conflitos entre } \\
\text { beneficiários e policiais }\end{array}$ & $\begin{array}{c}\text { O TCU recomendou } \\
\text { continuidade da capacitação } \\
\text { de policiais federais e policiais } \\
\text { dos estados que atuam na } \\
\text { proteção a vítimas e } \\
\text { testemunhas; }\end{array}$ & $\begin{array}{c}\text { Polícia Federal } \\
\text { treinou os policiais } \\
\text { nos Estados Unidos } \\
\text { com os Marshals, } \\
\text { para tomar conta de } \\
\text { cativeiro. }\end{array}$ \\
\hline Bolsa família & $\begin{array}{c}\text { Auditoria de } \\
\text { tecnologia da } \\
\text { informação (TI) }\end{array}$ & $\begin{array}{c}\text { O não atendimento a } \\
\text { necessidades dos gestores } \\
\text { municipais para utilização do } \\
\text { CadÚnico, indícios de } \\
\text { descumprimento da legislação } \\
\text { aplicável, ocorrência de erros e } \\
\text { indícios de fraudes, falhas de } \\
\text { segurança da informação, } \\
\text { deficiências no } \\
\text { acompanhamento e gestão do } \\
\text { sistema, além de falhas no } \\
\text { processo de contratação dos } \\
\text { serviços para } \\
\text { operacionalização do } \\
\text { CadÚnico. }\end{array}$ & $\begin{array}{c}\text { O TCU recomendou o } \\
\text { estabelecimento de novas } \\
\text { funcionalidades no sistema, } \\
\text { aperfeiçoamento do } \\
\text { treinamento dos seus } \\
\text { usuários, adequação à } \\
\text { legislação vigente, } \\
\text { averiguação de erros e } \\
\text { indícios de fraudes, além de } \\
\text { aperfeiçoamento dos } \\
\text { procedimentos de segurança } \\
\text { da informação, } \\
\text { acompanhamento e gestão do } \\
\text { CadUnico e dos pagamentos } \\
\text { de benefícios a ele } \\
\text { vinculados. }\end{array}$ & $\begin{array}{l}\text { Aperfeiçoamento do } \\
\text { cadastro único }\end{array}$ \\
\hline $\begin{array}{l}\text { Ações de } \\
\text { Esporte de Alto } \\
\text { Rendimento } \\
\text { (EAR) }\end{array}$ & Bolsa Atleta & $\begin{array}{l}\text { TCU constatou que a Bolsa- } \\
\text { Atleta, ação do governo federal } \\
\text { de repasse mensal, não é } \\
\text { focada nas modalidades } \\
\text { olímpicas e paraolímpicas }\end{array}$ & $\begin{array}{l}\text { O TCU recomendou que os } \\
\text { esportes olímpicos fossem } \\
\text { priorizados }\end{array}$ & $\begin{array}{l}\text { Reformulação da lei } \\
\text { para favorecer } \\
\text { esportes olímpicos e } \\
\text { paraolímpicos }\end{array}$ \\
\hline
\end{tabular}

Fonte: Pesquisa de campo realizada no Tribunal de Contas da União em 2015 
Verifica-se, portanto, que embora ainda existam questionamentos isolados sobre a competência do Tribunal em relação à função de avaliador e que o aprimoramento contínuo da metodologia aplicada na ANOp venha mitigando o questionamento sobre a técnica, o fator legitimidade não apresenta contradições relevantes. Nas declarações da instituição e de seus colaboradores a demanda social por informações fidedignas tem sustentado a continuidade desta prática.

Eu acho que deve continuar a realizar auditorias operacionais conjuntamente com outros tipos de fiscalização, porque ele agrega valor ao cidadão, à administração pública. Eu acho que ele agrega valor ao debate acadêmico não é? Eu acho que... que foi ... foi um trabalho, que se a gente pensar, ele tá sendo executado aí por menos de 20 anos, numa história de uma instituição que tem 124 anos. Numa história de um país democrático que tem aí... sei lá... vamos dizer dos anos 80 né? 80 , 90, menos 40 anos de democracia e que tem uma administração pública que... pelo menos o discurso é de mudança, de transparência, de accountability, resultado pro cidadão. Então eu acho que o controle externo ocupa um papel que é fundamental como muitos atores desse processo de levar ao cidadão conhecimentos sobre seus direitos e o que está sendo feito com seu dinheiro. sic. (Metodologia do processo de implementação da ANOp no TCU. TCU, 28 jan 15. Entrevista concedida a Helayne Rodrigues da Silva). 


\section{CONSIDERAÇÕES FINAIS}

Esta pesquisa descreveu o processo de institucionalização da Auditoria Operacional ANOp no TCU. Um processo isomórfico, de legitimação de técnicas e normas avaliativas voltadas à orientação de auditorias de desempenho realizadas por Entidades de Fiscalização Superior.

Conclui-se que a principal motivação para o desenvolvimento da ANOp adveio da reforma gerencial do Estado, que incluiu o conceito de resultado ao arcabouço da Nova Gestão Pública. A reforma administrativa foi, portanto uma "janela de oportunidade" que legitimou a atividade avaliativa no TCU.

Novas crenças e conceitos culturais refletindo mudanças nos aspectos políticos, econômicos e sociais promoveram um alargamento do entendimento e aceitação pragmática, moral e cognitiva da atividade de avaliação desempenhada por Entidades de Fiscalização Superior tanto dentro, quanto fora da instituição.

Nos últimos 35 anos, o Tribunal manteve pesquisas e atividades de cooperação técnicas internacionais voltadas ao desenvolvimento de práticas avaliativas. Este longo período de estudo proporcionou maior maturidade e credibilidade aos seus relatórios, somando-se ainda como fator de motivação ao desenvolvimento da ANOp no Tribunal, a especialização e capacitação técnica do recursos humanos, fruto do investimento na reconstrução das carreiras dos órgãos centrais, que proporcionaram a continuidade e fidedignidade de trabalhos longitudinais.

Por outro lado, observou-se que o Executivo vivenciou nas décadas de 1980 e 1990 um enfraquecimento de sua habilidade de gestão causadas pelo processo de fusão de órgãos e da alavancagem da terceirização, que impediram a estruturação de um corpo de profissionais qualificados e comprometidos com a causa do planejamento, tendo ações de longo prazo fragilizadas pela descontinuidade administrativa.

Por meio de leituras realizadas, acredita-se que este desnivelamento técnico entre órgãos setoriais e o órgão avaliador, proporcionou um distanciamento do objetivo principal da avaliação que é a retroalimentação do processo de gestão dos projetos e programas públicos, causando uma competição interinstitucional na disputa de recursos e âmbitos de ação. 
Os gestores necessitam constantemente de avaliações que proporcionem leituras capazes de orientar e redirecionar suas ações de forma rápida e contundente.

Destarte a discussão atual sobre a terceirização, que foi um dos pontos elencados acima, trata da tramitação do projeto lei 4.330/2004 - que regulamenta a atividade de terceirização e retoma reflexões não somente sobre direitos trabalhistas como a mídia vem propagando, mas sobre a qualidade e a longevidade do corpo burocrático da administração estatal.

A possibilidade de terceirização na atividade-fim ${ }^{81}$ conflita com estratégias de gestão voltadas para decisões guiadas por resultados. Historicamente, a mão de obra terceirizada tornou o serviço estatal mais precário mesmo aumentando sua produtividade em alguns setores como bancos e correios.

As características de autonomia e independência dos agentes avaliadores se relacionam diretamente a sua capacidade de aprimoramento dos canais e mecanismos de avaliação. Faz parte do processo de gestão apreender. O aprendizado é o esperado da avaliação, o diálogo contínuo mantido entre os gestores e administradores é muito importante quando se pretende trabalhar perto do seu objeto de ação.

Embora a avaliação possa contribuir para alcançar os objetivos, permitindo a reorientação das políticas que não estão contribuindo para consecução daqueles, pode ao mesmo tempo gerar uma ampla gama de conflitos Interburocráticos e com o nível político, tornando-a potencialmente perigosa e em suma, poderiam não interessar aqueles que deveriam leva-las adiante. ((COHEN, 1993, p. 70)).

Embora o incremento dos vínculos seja uma forma de validar a legitimidade cognitiva dos processos isomórficos, verificou-se que não há atividades de cooperação técnica entre o TCU e os Ministérios no sentido de implementar sistemas avaliativos próprios para 0 monitoramento e avaliação de seus programas.

Os problemas e/ou erros de diagnóstico, implementação e execução estão intrinsecamente ligados ao desenvolvimento de novos projetos. O caráter educador da avaliação deve oferecer ao gestor uma visão sistêmica de suas ações e cabendo a ele o redirecionamento das suas atividades, portanto, esse é o papel de quem faz a política.

\footnotetext{
${ }^{81}$ http://www.redebrasilatual.com.br/politica/2015/04/parlamentares-preparam-emendas-de-destaque-para-alterartexto-base-do-pl-4330-968.html
} 
O fato do gestor ser capaz de entender e intervir nos achados das avaliações sem receio de imputações legais ou coercitivas é também importante para o desempenho de suas atividades, pois, torna-se vital o compartilhamento das boas práticas que possam indiretamente, em órgãos não auditados, fomentar aprendizado por imitação e replicação de procedimentos ótimos.

Quanto às mudanças ocorridas durante o processo de implementação da ANOp, conclui-se que os relacionamentos internacionais mantidos pelo Tribunal, no intuito de promover a governança com ênfase na fiscalização por resultados aumentaram sua capilaridade de contatos. O fenômeno isomórfico mimético e normativo inicial proporcionou ao TCU maior participação e alteração de seu perfil no âmbito internacional.

Com base nas entrevistas, percebeu-se que o TCU desfruta hoje não somente de capacidade material-técnica, mas de posição influente na Intosai. Uma mudança de perfil, de receptor para doador, resultante da liderança de fóruns de discussão e da aplicação de treinamentos. Infere-se neste estudo que a participação de um "país emergente" em um fórum multilateral como interlocutor exceda os limites da organização e possibilite a abertura de canais para trocas de ideias e criação de identidades entre diferentes países.

Internamente, verificou-se que o processo isomórfico coercitivo foi importante para o aumento de recursos necessários a manutenção das práticas aplicadas na ANOp e no alinhamento das atividades do Tribunal com as questões sociais. A competência constitucional de avaliar, a especialização das secretarias do Tribunal por áreas de ação do governo, a incorporação na Auditoria de Conformidade do Mapa de Achados (ferramenta desenvolvida pra ANOp), demonstram que a tradição patrimonialista e autoritária do Brasil ainda exerce influência em transformações organizacionais.

É importante que além de assimilar as técnicas, seja necessário assimilar os valores que deram origem à visão da gestão por resultados, pois a avaliação se orienta pelo olhar do autor que a executa. Existe uma posição causal do Tribunal como ator político que pode influenciar a percepção do gestor quanto às recomendações dos relatórios da auditoria operacional, deixando claro que o sentido informativo pode ser substituído pelo coercitivo.

A desconcentração da função de avaliar das instituições implementadoras do Executivo em consequência da inoperância e da não funcionalidade das políticas públicas não deve resultar na judicialização das avaliações. Há necessidade de compreender e compatibilizar as 
funções. "O Controle de símbolos constitui-se em uma base de poder". (PFEFFER,1981 apud MARCH; OLSEN).

O conhecimento pleno do objeto demanda um olhar multidimensional dos fatos que necessita de maior tempo de pesquisa. Em decorrência dessa limitação, não foi possível levantar as opiniões dos gestores que participaram das auditorias operacionais e do DFID, órgão que promoveu o contato entre o NAO e o TCU.

Não há informação institucional que esclareça como os gestores utilizaram os relatórios do TCU para reorientar suas ações e em que ciclo das políticas públicas aplicaram este conhecimento. $\mathrm{E}$ ainda, a nível internacional carece aprofundamento sobre a motivação por parte do governo Britânico para desenvolvimento de um programa especifico de Governança, baseado na metodologia de Valeu for Money, direcionado exclusivamente a Entidades de Fiscalização Superior no mundo. ${ }^{82}$

Quanto à constatação dos resultados obtidos, ressalta-se que a principal característica da ANOp, sua flexibilidade, proporciona uma amplitude na escolha dos objetos e dos critérios, nas interpretações e formas de comunicar suas conclusões que resultam na atuação em diversos setores sociais e econômicos do país, como Administração Pública, agricultura, assistência social, ciência e tecnologia, comunicações, direitos humanos, direitos da cidadania, educação, energia elétrica, esportes, gestão ambiental, habitação, saneamento, indústria, comercio, previdência social, relações exteriores, segurança pública, trabalho e transporte.

As determinações e recomendações dos relatórios além de propor mudanças nas formas e estruturas dos programas, apontam melhorias de processos e racionalização de atividades que podem, em certos momentos, exceder a esfera do gestor.

São vários os relatórios de auditoria operacional publicados na forma de folders, o que facilita a leitura do escopo do trabalho e suas sugestões, contudo é incipiente ainda a divulgação dos resultados alcançados pela ANOp após os ajustes dos gestores. Existe o esforço do Tribunal em sistematizar estes dados por meio da criação dos relatórios sistêmicos de fiscalização, FISC.

\footnotetext{
${ }^{82}$ http://www.nao.org.uk/about-us/what-we-do/international-activities/\#coop
} 
De acordo com todo o exposto, conclui-se que o processo de institucionalização da Auditoria Operacional no TCU teve início com ações isoladas baseadas em interesses institucionais de homogeneização de procedimentos, mas a sua aceitação reside na mudança de paradigma da sociedade que demanda maior transparência e efetividade das ações governamentais.

O Controle, característica das Entidades de Fiscalização Superior, ao mesmo tempo em que proporciona maior segurança, pode enviesar a aplicação da informação.

Finalmente, constata-se que é positiva a função de avaliar do Tribunal, desde que sem exclusividade e respeitando-se o papel informativo desta atividade. Diante disso, sugere-se:

a) Que as práticas aplicadas na ANOp sejam compartilhadas e multiplicadas com os órgãos setoriais por intermédio de treinamento fornecidos pelo TCU;

b) Que o TCU estenda seus trabalhos para executar metas-avaliações capazes de verificar as avaliações realizadas pelas unidades gestoras;

c) Que sejam realizadas pesquisas com os Gestores que sofreram auditorias operacionais para verificar a perspectiva dos usuários dos relatórios. 


\section{BIBLIOGRAFIA}

ABC. Diretrizes para o desenvolvimento da Cooperação Técnica Internacional multilateral e bilateral/Ministério das Relações Exteriores. 2ª ed.-Brasília: Agencia Brasileira de Cooperação, 2004.

ALBUQUERQUE, Frederico de Freitas Tenório. A auditoria operacional e seus desafios: um estudo a partir da experiência do Tribunal de Contas da União. 153f. Dissertação (Mestrado Profissional em Administração) - Escola de Administração, Universidade Federal da Bahia, Salvador, 2006.

ARAÚJO, Inaldo da Paixão Santos. Introdução à Auditoria Operacional. Rio de Janeiro: Editora FGV, 2001.

BARZELAY, Michael. Central Audit Institutions and Performance Auditing: A Comparative Analysis of Organizational Strategies in the OECD. Governance, Malden, vol. 10, n.3, p. 235260, jul. 1997.

Brasil. Ministério da Administração Federal e Reforma do Estado / Secretaria da Reforma do Estado Organizações sociais. / Secretaria da Reforma do Estado. Brasília: Ministério da Administração e Reforma do Estado, 1997. 74 p. (Cadernos MARE da reforma do estado; v. 2)

CEPAL COMISSÃO ECONÔMICA PARA A AMÉRICA LATINA E O CARIBE Escritório no Brasil Planejamento no Brasil: auge, declínio e caminhos para a reconstrução - Fernando Rezende. LC/BRS/R.205 Junho de 2009

Complexidade e desenvolvimento/Organizadores: Jose Celso Cardoso Jr., Carlos Henrique Romão de Siqueira. - Brasília: Ipea, 2011. V. 3 (275 p.): tabs. -(Diálogos para 0 desenvolvimento).

COHEN, Ernesto. Avaliação de projetos sociais. Petrópolis, RJ: Vozes, 1993.

DAUJOTAITE, Dalia and MACERINSKIENE, Irena. Development of Performance Audit in Public Sector. $5^{\text {th }}$ InternationalScientificConference Business and Management.2008. Lithuania.

DFID. Equidade, Controle Social e Governança na Gestão Publica: A Contribuição das Avaliações de Programas Governamentais realizadas pelos Tribunais de Contas. Projeto CERDS - Relatório sobre Resultados Alcançados. DFID, BRAZIL.2006.

DIMAGGIO, Paul; POWELL, Walter. The Iron Cage Revisited: Institutional Isomorphism and Collective Rationality in Organizational Fields. In: American Sociological Review, Vol. 48. 1983.

DOLOWITZ, David and MARSH, David. Learning from Abroad: The Role of Policy Transfer in Contemporary Policy-Making.Governance: An international Journal of Policy and Administration, Vol.13, No. 1, January 2000 (pp 5-24).

FOUCAULT, Michel. A governamentalidade. in: ID., Microflsica do poder, Rio de Janeiro, Graal,. 1979. 
FREITAS, Carlos Alberto Sampaio. Aprendizagem, Isomorfismo e Institucionalização: O Caso da Atividades de Auditoria Operacional no Tribunal de Contas da União. Dissertação (Mestrado em Administração). Faculdade de Economia, Administração e Contabilidade. Universidade de Brasilia, Brasilia, 2005.

FRYDMAN, B; Santos, ER; Dias, MCT; Modenesi, RL; Magalhães, WA. Metodologia de Análise de Projetos - Brasília, BNDES, 1986.

HOWLETT, Michael.1955 Política Publica: seus ciclos e subsistemas, uma abordagem integrada/Michael Howlett, M. Ramesh, Anthony Perl; tradução técnica Francisco G. Helderman - Rio de Janeiro: Elsevier, 2013.

INTOSAI (2001c), "Field Standards in Government Auditing", International Standards of Supreme Audit Institutions (ISSAI), 300, INTOSAI Professional Standards Committee, Copenhagen. Disponível em: <www.issai.org.> Acesso em: 8 nov 2014.

KNILL, Christoph and TOSUN, Jale. Policy-Making. In: CARAMANI, Daniele. Comparative Politics, 2nd Edition. Oxford University Press, 2011.

LIMA, Dagomar Henriques. A importância da avaliação para a gestão de políticas públicas e para a responsabilização por desempenho. Texto TCU. Disponível em: <www.tcu.org.br>. Acesso em: 25 nov 2014.

LIMA, Dagomar Henriques. Auditoria de natureza operacional, auditoria de desempenho, auditoria de desempenho operacional e avaliação de programa. Texto TCU. Disponível em: $<w w w . t c u . o r g . b r>$. Acesso em: 25 nov 2014.

MARCH, James G and OLSEN, Johan P. Neo-institucionalismo: fatores organizacionais na vida política. Rev. Sociol. Polit. [online]. 2008, vol.16, n.31, pp. 121-142. ISSN 0104-4478. http://dx.doi.org/10.1590/S0104-44782008000200010.

NARDES, João Augusto Ribeiro. O Controle Externo como Indutor da Governança em Prol do Desenvolvimento. In: XXV Forum Nacional: O Brasil de Amanha Transforma Crise em Oportunidade. INAE. Rio de Janeiro, 2013.

ORGANIZAÇÕES, INSTITUIÇÕES E PODER NO BRASIL. Marcelo Milano Falcão Vieira e Cristina Amélia Carvalho (Orgs.). Rio de Janeiro: Editora FGV, 2003. 324p. ISBN 8522504407.

OECD. Brazil's Supreme Audit Institution: The Audit of the Consolidated Year-end Government Report. OECD Public Governance Reviews. 2012

Ogunyemi, Ayodeji. Discussion Paper on the role of an effective Supreme Audit Institution in the Reform of Service Delivery and Public Sector Performance. OECD Global Forum on Governance: Modernising Government: Strategies \& tools for Change.

Portal audit-comission UK, Disponível em :<http://www.audit-commission.gov.uk/aboutus/procurement-and-spending/>. Acesso em : 16 jan 2015.

Portal Nation Audit Office, Disponível em : <http://www.nao.org.uk/about-us/what-wedo/international-activities/technical-co-operation-strengthening-audit-capacity-internationally/>. Acesso em : 6 out 2014. 
Portal The International Organisation of Supreme Audit Institutions (INTOSAI), Disponível em: $<$ www.intosai.org >. Acesso em: 18 nov 2014

PORTARIA-SEGECEX No 4, MANUAL DE AUDITORIA OPERACIONAL, DE 26 DE FEVEREIRO DE 2010

PORTARIA-SEGECEX № 31, Análise SWOT e Diagrama de Verificação de Risco Aplicados em Auditoria, DE 9 DE DEZEMBRO DE 2010

RADOMSKY, Guilherme Francisco Waterloo. Pós-Desenvolvimento, Indicadores e Culturas de Auditoria: Reflexões Criticas sobre Governança e Desenvolvimento. Ciências Sociais Unisinos, vol.49, num 2, maio-agosto, 2013, pp 155-163. Universidade do Vale do Rio dos Sinos. São Leopoldo, Brasil.

SABAH, Fernanda. A criação dos organismos internacionais sob a égide do estado de bemestar social. In: Âmbito Jurídico, Rio Grande, XIII, n. 73, fev 2010. Disponível em:<http://www.ambitojuridico.com.br/site/index.php?n_link=revista_artigos_leitura\&artigo_id=7 195

SANTOS, Adriana Rodrigues dos. Monitoramento e avaliação de programas no setor público [manuscrito] : a experiência do PPA do Governo Federal no período 2000-2011 / Adriana Rodrigues dos Santos. -- 2012. $69 \mathrm{f}$.

Secretaria de Assuntos Estratégicos da Presidência da República (SAE/ PR) - Agenda Nacional de Gestão 2009

SERPA, Selma Maria Hayakawa Cunha. Para que Avaliar? Identificando a Tipologia, os Propósitos e a Utilização das Avaliações de Programas Governamentais no Brasil. Dissertação (Mestrado em Administração) - Escola de Administração, Universidade Federal Brasília Brasília, 2010.

SILVA, Adival do Carmo. Evolução da administração pública no Brasil e tendências de novos modelos organizacionais. Disponível: http://www.ice.edu.br/TNX/storage/webdisco/2013/12/13/outros/27b4d512efbac7d37520bc37aa 78cac1.pdf

STEIN, Ernesto et alli. A politica das politicas publicas: Progresso Econômico e Social na América Latina. Relatório 2006. Ed. Campus, 2 ed. (capítulos 2, 6 e 7).

STRATHERN, M. 2000 introduction: new accountabilities. In: M. STRATHERN (ed.) Audit Cultures: anthropological studies in accountability, ethics, and the academy. London: New York, Routledge.

SUCHMAN, Mark C. Managing legitimacy: strategican dinstitutional approaches. Academy of Management Review, v. 20, n. 3, p. 571-610, 1995.

Talbot, Colin. PERFORMANCE IN GOVERNMENT: The Evolving System of Performance and Evaluation Measurement, Monitoring, and Management in the United Kingdom. $\mathrm{N}^{\circ} 24$. November 2010. ECD WORKING PAPER SERIES

VERGARA, Sylvia Constant. Projetos e relatórios de pesquisa em administração. São Paulo: Atlas, 2007. 
WALDO, Dwight. The Administrative State: A Study of the Political Theory of American Public Administration. New Brunswick (USA): Transaction Publishers, 2007.

WORTHEN, Blaine R. Avaliação de Programas: Concepções e práticas/Blaine R. Worthen, James R. Sanders, Jody L. Fizpatrick; traducao Dinah de Abreu Azevedo. São Paulo: Ed. Gente/EDUSP/Instituto Fonte/Instituto Ayrton Senna, 2004. 